UNIVERSIDADE DE SÃO PAULO

FACULDADE DE EDUCAÇÃO

NADIA MOURA FARHAT

Saberes pedagógicos: um estudo com docentes de pós-graduação lato sensu de uma IES

São Paulo - SP 2017 

NADIA MOURA FARHAT

\title{
Saberes pedagógicos: um estudo com docentes de pós-graduação lato sensu de uma IES
}

\author{
VERSÃO CORRIGIDA
}

Dissertação apresentada ao Programa de PósGraduação da Faculdade de Educação - USP, para obtenção do título de Mestre em Educação.

Orientadora: $\operatorname{Prof}^{a} \mathrm{Dr}^{\mathrm{a}}$ Maria de Lourdes Ramos da Silva

$$
\begin{gathered}
\text { São Paulo - SP } \\
2017
\end{gathered}
$$


Autorizo a reprodução e divulgação total ou parcial deste trabalho, por qualquer meio convencional ou eletrônico, para fins de estudo e pesquisa, desde que citada a fonte.

\author{
Catalogação na publicação \\ Serviço de Biblioteca e Documentação \\ Faculdade de Educação da Universidade de São Paulo
}

Farhat, Nadia Moura

F223a

Saberes pedagógicos: um estudo com docentes de pós-graduação lato sensu de uma IES / Nadia Moura Farhat; orientação Maria de Lourdes Ramos da Silva. São Paulo: S.n., 2017.

161 p.; apêndices; anexo

Dissertação (Mestrado - Programa de Pós-Graduação em Educação. Área de Concentração: Psicologia e Educação) - Faculdade de Educação da Universidade de São Paulo.

1. Formação de professores. 2. Professores de Ensino Superior. 3. Pedagogia. 4. Ensino e aprendizagem. 5. Pós-graduação. 6. Didática. I. Silva, Maria de Lourdes Ramos da, orient. 
FARHAT, Nadia Moura

Saberes pedagógicos: um estudo com docentes de pós-graduação lato sensu de uma IES

Dissertação apresentada ao Programa de Pós-Graduação da Faculdade de Educação - USP, para obtenção do título de Mestre em Educação.

Aprovada em:

\section{Banca Examinadora}

Prof. Dr.

Instituição:

Julgamento:

Prof. Dr.

Instituição:

Julgamento:

Prof. Dr.

Instituição:

Julgamento: 

A meu marido, Alessandro, e a meus pais, Lea e Aziz 



\section{AGRADECIMENTOS}

À $\operatorname{Prof}^{\mathrm{a}} \mathrm{Dr}^{\mathrm{a}}$ Maria de Lourdes Ramos Silva, pelo acompanhamento e pela orientação durante toda a elaboração deste estudo.

Ao Prof. Dr. Roberto Galassi Amaral e à Prof ${ }^{a}$ Dr $^{a}$ Helena Coharik Chamlian, pelas valiosas contribuições no exame de qualificação e pelo incentivo à continuidade do trabalho.

Aos colegas Prof. Dr. Thomaz Wood Jr., Dr. Conrado Schlochauer, Dr. Eduardo C. Humes e Me. Desirèe M. Cordeiro, que me inspiraram com sua experiência acadêmica e me estimularam com suas preciosas sugestões.

A minha mãe e grande amiga, Lea, que sempre me acompanhou e incentivou em todas as dúvidas e certezas da vida - sendo uma delas a de conseguir entrar e concluir este mestrado.

A meu querido pai, Aziz, que me influenciou com sua paixão pela leitura e pelo conhecimento, além do exemplo de paciência para realizar o que desejamos.

A meu irmão, Daniel, meu primeiro "aluno", na infância, que me permitiu descobrir logo cedo a paixão de ensinar.

A meu marido e melhor amigo, Alessandro, que me apoiou desde a seleção, respeitou os isolamentos que o mestrado me exigiu e que também aprendeu sobre saberes pedagógicos.

Aos familiares e amigos, especialmente a minha avó Alzira e a minha tia Elisabete, pela constante ajuda, não apenas durante o mestrado, mas ao longo de toda a vida.

Muito obrigada a todos por haverem participado desta intensa jornada! 



\section{RESUMO}

FARHAT, Nadia Moura. Saberes pedagógicos: um estudo com docentes de pósgraduação lato sensu de uma IES. 2017. 161 p. Dissertação (Mestrado em Educação) - Faculdade de Educação, Universidade de São Paulo, 2017.

Esta pesquisa investiga os saberes pedagógicos de docentes do lato sensu. Para tanto, inicialmente, contextualiza o ensino superior no Brasil e a composição dos saberes docentes: disciplinares, experienciais e pedagógicos. Destes, explicitaram-se a composição e sua inter-relação com a identidade profissional docente, considerando a pedagogia universitária e didática, o processo de ensino e aprendizagem de adultos, o planejamento pedagógico, a prática pedagógica em aula, a formação docente e pesquisas recentes sobre o tema. A pesquisa de campo coletou o perfil dos docentes num questionário on-line e depois, por meio de entrevistas semiestruturadas, os saberes pedagógicos de oito docentes da IES selecionada. Os resultados confirmaram a hipótese inicial. Constatou-se que eles praticamente não tiveram formação pedagógica prévia a sua atuação docente, mas se conscientizaram da importância desses saberes durante seu desenvolvimento profissional, a partir da prática de sala de aula, sem contar com uma fundamentação teórica educacional. As principais dimensões pedagógicas destacadas nas declarações foram a relação construtiva com os alunos e o desenvolvimento de seu pensamento crítico e complexo. Essas constatações subsidiaram propostas relevantes como dar voz aos alunos do lato sensu para que se complementem os resultados obtidos, intensificar o repertório de metodologias que promovam a autonomia do aluno, ampliar a responsabilidade da IES mediante a promoção e o desenvolvimento de ações pedagógicas formativas com o apoio dos coordenadores dos cursos lato sensu e mobilizar o Ministério da Educação (MEC) para fortalecer a regulamentação desses cursos.

Palavras-chave: Formação de professores. Professores de Ensino Superior. Pedagogia. Ensino e aprendizagem. Pós-graduação. Didática. 



\begin{abstract}
FARHAT, Nadia Moura. Pedagogical know-how: a study with the faculty of a postgraduate diploma program in Brazil. 2017. 161 p. Dissertação (Mestrado em Educação) - Faculdade de Educação, Universidade de São Paulo, 2017.

The present study aims to investigate the pedagogical know-how of postgraduate diploma professors. In order to do so, it shall first contextualize higher education in Brazil and the constitution of a faculty's disciplinary, experiential and pedagogical know-how. It shall focus on such constitution and its interrelation with teachers' professional identity, taking into account university and didactic pedagogy, adult teaching and learning processes, pedagogical planning, pedagogical practice in classrooms, teacher training, and recent studies on the topic. Our field research collected teachers' profiles by means of an online questionnaire. Then, the pedagogical know-how of eight professors from the selected higher education institution was assessed with semi-structured interviews. The results confirmed our initial hypothesis: most of them had not undergone pedagogical training before they started teaching; they noticed their classroom practice lacked a theoretical framework and became aware of its importance during their professional development. The main pedagogical dimensions highlighted in their testimonies were constructive relationships with students, and the development of complex and critical thinking. These findings supported relevant propositions such as giving voice to students so as to complement the results achieved, enhancing the repertoire of methodologies that promote students' autonomy, increasing the institution's responsibility by promoting and developing pedagogical training with the support of postgraduate diploma coordinators, and mobilizing the Brazilian Ministry of Education (MEC) to strengthen the regulation of these programs.
\end{abstract}

Keywords: Teacher training. Teachers of Higher Education. Pedagogy. Teaching and learning. Postgraduate studies. Didactics. 



\section{SUMÁRIO}

INTRODUÇÃO ............................................................................. 17

CAPÍTULO 1

O CENÁRIO E OS ATORES ........................................................... 25

1.1 Contextualização do ensino superior no Brasil ............................. 25

1.2 Os cursos de pós-graduação lato sensu ....................................... 34

1.3 A IES selecionada, seus docentes e alunos da pós-graduação lato sensu ............................................................................. 36

CAPÍTULO 2

OS SABERES PEDAGÓGICOS DOCENTES …................................ 41

2.1 A composição dos saberes docentes ......................................... 41

2.2 Identidade profissional docente .................................................. 46

2.3 Saberes pedagógicos dos docentes do ensino superior ............... $\quad 50$

2.3.1 Pedagogia universitária e didática ...................................... 51

2.3.2 Processo de ensino e aprendizagem de adultos .................. 53

2.3.3 Planejamento pedagógico ………………………........... 56

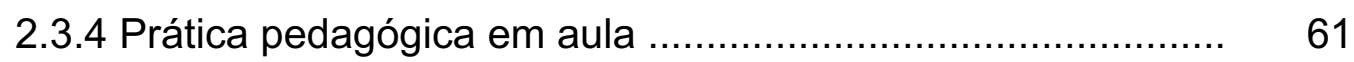

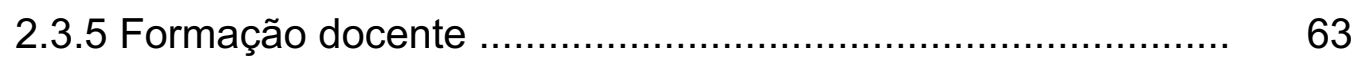

2.3.6 Pesquisas recentes sobre o tema ......................................... 68

CAPÍTULO 3

SABERES PEDAGÓGICOS DE DOCENTES DO LATO SENSU DE UMA IES EM SÃO PAULO …………………………......................

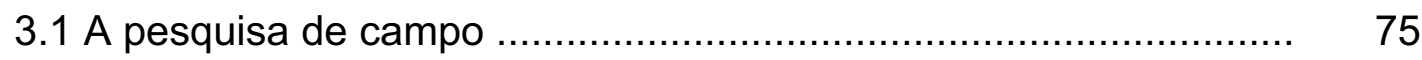

3.2 Perfil dos docentes entrevistados ................................................. 78

3.3 Saberes pedagógicos dos docentes do lato sensu da IES

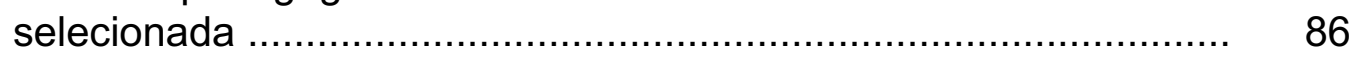

3.3.1 Cursos lato sensu e identidade docente ............................. 88

3.3.2 Formação e desenvolvimento docente ................................. 100

3.3.3 Saberes pedagógicos e prática docente .............................. 106

3.3.4 Papel dos saberes pedagógicos e autorreflexão docente ..... 130 CONCLUSÃO .......................................................................... 143

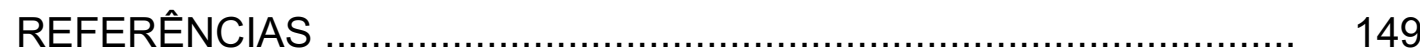

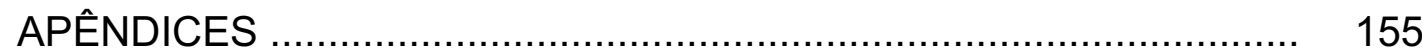

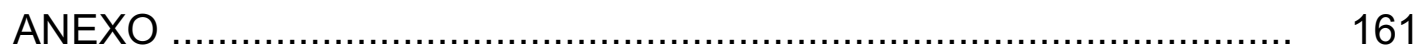





\section{INTRODUÇÃO}

Este trabalho investiga os saberes pedagógicos de docentes de cursos de pósgraduação lato sensu e a forma como são aplicados em sua atuação profissional. Embora nem sempre sejam devidamente reconhecidos no universo acadêmico, esses docentes e os seus saberes precisam e merecem ser mais bem compreendidos.

Trata-se de um grupo diferenciado de professores, com um perfil heterogêneo, que precisam conciliar os conhecimentos da disciplina que ministram com a experiência adquirida durante sua trajetória profissional docente. Eles lecionam em cursos de pós-graduação lato sensu, que visam dar ao aluno uma formação educacional, assegurando-lhe, concomitantemente, uma aprendizagem pragmática que o habilite a enfrentar as constantes mudanças do mercado de trabalho.

Entretanto, pairam algumas dúvidas: será que esses professores têm formação pedagógica capaz de garantir a aprendizagem de seus alunos? Como eles percebem seus saberes pedagógicos e como os aplicam em aula? Que papel e importância atribuem a esses saberes?

Essas perguntas nortearam esta pesquisa, com a finalidade de contribuir com a reflexão dos docentes do lato sensu e de sensibilizar as instituições de ensino superior (IES) que desenvolvem esses cursos.

Meu interesse pelo tema vem acompanhando minha atuação docente há anos, mas, à medida que adquiria experiência e novos aprendizados, senti a necessidade de um melhor desenvolvimento profissional.

Esse interesse se estende às representações que construímos ao longo de nossa vida e que são fundamentais para nossa escolha profissional em diversos momentos. Assim, resgatando minhas lembranças das primeiras manifestações de identificação com a docência, vejo-me com 10 anos de idade, brincando de ser professora do meu irmão.

Mesmo que essa situação se tenha repetido muitas vezes e eu passasse a sentir um grande prazer em ensinar às pessoas o que sabia, levei algum tempo para relacionar essa identificação ao desejo de trabalhar como professora em instituições 
educacionais. Na verdade, foi só depois de me graduar em administração que me apaixonei pela relação que se constrói entre ensino e aprendizagem. E essa paixão se acentuou ainda mais quando comecei a treinar a equipe que liderava, o que me levou a cursar uma especialização em recursos humanos.

A descoberta se consolidou com o passar do tempo e com a sucessiva condução de treinamentos corporativos, o que foi decisivo no desenvolvimento de meus atuais saberes docentes, construídos na própria prática.

Gradativamente, comecei a concentrar meu trabalho na formação de multiplicadores, que ensinariam conteúdos técnicos relativos a diversas áreas, sempre com ênfase no processo de ensino e aprendizagem. Ainda que não fosse totalmente consciente, considero que essa atuação já fazia parte da afinidade que fui desenvolvendo com o processo de formação de docentes, afinidade essa que viria a se concretizar futuramente.

Na mesma época, devido ao meu conhecimento e à minha experiência na área de gestão de pessoas, fui convidada a lecionar em cursos de pós-graduação lato sensu numa instituição de ensino superior.

Logo nas primeiras aulas, compreendi que precisaria de uma formação complementar, e o mestrado não seria apenas importante, mas necessário. Assim, algumas disciplinas cursadas no mestrado na linha de educação, linguagem e psicologia da FEUSP ampliaram minha visão e meu conhecimento da área educacional.

Paralelamente, como consultora educacional, tive a chance de expandir meus saberes sobre educação corporativa assim como sobre o desenvolvimento de soluções educacionais, que ajudaram a aprimorar minhas aulas nos cursos lato sensu.

Foi essa busca por um desenvolvimento profissional permanente que me levou a estudar os saberes docentes. Segundo Tardif (2002), os saberes docentes são os conhecimentos e as habilidades mobilizados para a realização do processo de ensino e aprendizagem em sala de aula e podem ser classificados como: saberes disciplinares (conteúdos da área do conhecimento), saberes experienciais (prática profissional) e saberes pedagógicos (conceitos e práticas educacionais). 
No caso dos docentes do lato sensu, eles são reconhecidos sobretudo por sua atuação no mercado de trabalho justamente na área em que lecionam. Esse reconhecimento se dá tanto pelos alunos como pelas próprias IES, já que essa atuação Ihes permite relacionar seus saberes disciplinares com os experienciais, respondendo à finalidade precípua de tais cursos, que é o desenvolvimento profissional do sujeito.

Entretanto, apesar desse entrelaçamento entre saberes disciplinares e experienciais que presenciamos cotidianamente, não conhecemos claramente a composição dos saberes pedagógicos desses docentes do lato sensu e como são aplicados ao processo de ensino e aprendizagem.

Tal inquietação foi a base desta pesquisa, que se propõe a investigar de que forma os professores de cursos de pós-graduação lato sensu desenvolvem seus saberes pedagógicos ao longo da trajetória profissional e como os aplicam às disciplinas que lecionam.

De modo geral, podemos afirmar que os saberes pedagógicos abrangem: (1) um conjunto de conhecimentos e práticas que envolvem o planejamento e a adequação de um currículo formativo para os alunos, (2) o trabalho do professor como pesquisador com vistas ao aprimoramento e à permanente atualização, (3) a articulação das estratégias e metodologias de aprendizagem para o alcance dos objetivos propostos, (4) a relação construtiva com os alunos e (5) a avaliação adequada de sua aprendizagem. Todos esses elementos em conjunto levam ao desenvolvimento constante da disciplina, do docente e também da instituição de ensino.

O docente dos cursos lato sensu é, primeiramente, um ser humano complexo e um profissional sempre em desenvolvimento. Independentemente de seu perfil e das horas que dedica à docência, ele sente o contínuo desafio de ensinar e garantir a aprendizagem de seus alunos. Contudo, esse desafio se torna ainda mais contundente quando os alunos já são adultos e estão no mercado de trabalho, com diferentes necessidades e expectativas profissionais. 
Como esses professores têm um papel relevante no desenvolvimento profissional dos alunos, consideramos imprescindível esclarecer como percebem a importância dos saberes pedagógicos em sua prática docente.

Acreditamos que os resultados obtidos podem ser uma referência para os docentes do lato sensu, na medida em que podem subsidiar a análise dos saberes pedagógicos desenvolvidos até o momento, ajudando-os a entender os pontos fortes e frágeis de sua prática para que logrem conduzir melhor o processo de ensino e aprendizagem.

No que tange às IES, os dados disponibilizados podem ser úteis para revisar os critérios de seleção de docentes de cursos lato sensu, assim como para aprimorar sua formação contínua e acompanhar sua atuação, questões decisivas para o aprimoramento do processo de ensino e aprendizagem desses cursos.

Dessa forma, os docentes que lecionam nesses cursos devem saber articular os saberes sobre sua disciplina e os adquiridos ao longo da experiência profissional - que são geralmente muito valorizados pelos alunos. Já os saberes pedagógicos acabam relegados e só são lembrados diante de dificuldades concretas ou por uma sensibilização durante a construção da identidade profissional docente.

Os docentes do lato sensu têm identidades profissionais distintas e em permanente construção. Sua formação acadêmica consiste em especialização, mestrado ou doutorado, e grande parte atua também no mundo empresarial, o que Ihes dificulta o adequado enfrentamento das responsabilidades e atividades docentes.

Independentemente da formação, os docentes do lato sensu precisam de estímulo e apoio constante para refletir sobre sua identidade profissional e para o desenvolvimento contínuo de seus saberes, o que geralmente fazem por iniciativa própria ou em cursos complementares, que não dão a visão pedagógica integral necessária à docência.

Portanto, o principal objetivo deste trabalho é investigar os saberes pedagógicos (conhecimento e prática) de docentes de cursos de pós-graduação lato sensu com base numa amostra pertencente a uma IES da cidade de São Paulo selecionada por sua tradição e abrangência nacional nessa modalidade. 
Como hipótese, consideramos que os saberes pedagógicos dos docentes do lato sensu são heterogêneos e pouco desenvolvidos, construídos ao longo de sua prática docente e de acordo com a necessidade ou o interesse do momento, sem o apoio de uma formação pedagógica consistente.

Para tanto, analisaram-se as dimensões que podem sustentar essa hipótese: a fragilidade da regulamentação e da avaliação dos cursos lato sensu, a não obrigatoriedade da formação pedagógica para a docência no ensino superior, a desvalorização da docência diante da pesquisa no meio acadêmico, as limitações do vínculo de trabalho com as IES e as poucas horas de dedicação à docência, que dificultam iniciativas de formação continuada.

Este estudo é composto por duas partes: uma pesquisa teórica apresentada em dois capítulos e a pesquisa de campo com uma amostra de oito docentes de três cursos de pós-graduação lato sensu da IES selecionada em São Paulo.

O Capítulo 1 apresenta o cenário em que trabalham esses docentes e dados sobre o ensino superior, os cursos lato sensu e seus atores (docentes e alunos). objetivo é compreender brevemente o histórico e o desenvolvimento desses docentes, assim como a situação em que se encontram hoje.

Pesquisaram-se referências sobre o histórico e a evolução do ensino superior no Brasil para contextualizar as IES nos dias atuais. Os principais autores consultados foram Sacristán (1995), Berbel (1994), Bosi (2007), Chamlian (2006), Chaves (2010), além dos dados do último Censo 2014 (INEP, 2016) e das metas do Plano Nacional de Educação (PNE) (MEC, 2014).

Em seguida, descrevem-se a instituição de ensino selecionada e o perfil de seus docentes e alunos, em função das regulamentações da Lei de Diretrizes e Bases (LDB) (Presidência da República, 1996), do Ministério da Educação (MEC, 2014) e das contribuições de Gonçalves (2013), Gaeta e Masetto (2013), Oliveira (1995) e Oliveira e Cunha (2009).

No Capítulo 2, caracterizam-se os saberes docentes, apoiados sobretudo em propostas dos autores da área de educação: Tardif (2002), Pimenta (2007), Masetto (2003, 2014) e Vasconcelos (2014). Quanto à identidade profissional docente, 
destacamos os estudos de Silva (2007, 2009), Hall (2006), Ferreira (1996), Melucci (2004), Nóvoa (1992) e Esteve (1995).

Para compreender os saberes pedagógicos, resgatamos os conceitos de Tardif (2002) e Masetto (2014), transpondo-os para os saberes dos docentes de cursos de pós-graduação lato sensu e acrescentando as contribuições de Gonçalves (2013), que desenvolveu pesquisa sobre os saberes e as práticas docentes do lato sensu na mesma instituição selecionada.

O capítulo segue com uma descrição mais detalhada dos saberes pedagógicos a partir das categorias: pedagogia universitária e didática; o processo de ensino e aprendizagem de adultos; o planejamento pedagógico; a prática pedagógica em aula; a formação docente e pesquisas atuais sobre o tema. Os conceitos e propostas que fundamentam essas categorias são de: Almeida (2012), Aquino (2007), Bireaud (1995), Bloom (1956), Chamlian (2003, 2006), Esteve (1995), Gonçalves (2013), Knowles (1980), Masetto (2003, 2010, 2014), Nóvoa (1992, 1995, 2016), Pimenta e Anastasiou (2011), Rogers (1985), Sacristán (1995), Soares (2009), Tardif (2002), Vasconcelos (2014) e Zabalza (2004).

No Capítulo 3, discute-se a pesquisa de campo, desenvolvida com oito docentes de uma IES em São Paulo. Investigou-se a visão dos sujeitos com relação a seus próprios saberes pedagógicos, com base nas propostas sobre pesquisa qualitativa em educação de Ludke e André (1986), Alves (1991) e André (2001).

Optamos pela abordagem qualitativa porque ela favorece a verificação subjetiva dos saberes mobilizados pelos docentes, de seus comportamentos e de suas atitudes em sala com os alunos, além das perspectivas e das experiências que eles desenvolvem em classe.

Além disso, a pesquisa qualitativa permite entender melhor a identidade profissional e analisar a situação em que se encontra o docente, que precisa ter uma prática educacional flexível para conduzir o processo de ensino e aprendizagem.

Com o apoio da IES escolhida, um grupo de coordenadores de cursos lato sensu indicou os contatos de seus respectivos docentes. A pesquisa de campo 
transcorreu em duas etapas: levantamento de informações iniciais a partir de um questionário on-line e entrevistas individuais com roteiro semiestruturado.

Entramos em contato com 39 docentes do lato sensu, representando $93 \%$ do total na IES no primeiro semestre de 2016. Responderam à pesquisa on-line 16 docentes (41,03\% da amostra), com as seguintes informações: gênero, idade, titulação, formação acadêmica, tempo de docência, horas de dedicação semanal à docência, cursos que leciona na IES, tipo de contratação e a atual dedicação exclusiva à docência.

$\mathrm{Na}$ segunda etapa, dos 16 docentes participantes novamente convidados, oito concordaram em ser entrevistados. Na entrevista individual, perguntou-se sobre sua visão dos cursos lato sensu, o papel e as responsabilidades do docente do lato sensu e, com mais ênfase, sobre seu entendimento dos saberes pedagógicos nos seguintes aspectos:

- se tinham formação pedagógica prévia e qual;

- desenvolvimento e composição atual de seus conhecimentos e práticas;

- sua visão sobre o papel e a importância dos saberes pedagógicos no processo de ensino e aprendizagem;

- os pontos fortes e os pontos a desenvolver de seus saberes pedagógicos.

A análise dos dados coletados com os oito docentes participantes permitiu a categorização dos resultados e ensejou considerações relevantes e contribuições para os docentes do lato sensu e para a própria IES. 


\section{CAPÍTULO 1 \\ O CENÁRIO E OS ATORES}

\subsection{Contextualização do ensino superior no Brasil}

Com a finalidade de investigar os saberes pedagógicos desenvolvidos pelos docentes do lato sensu, é importante considerar não só esses docentes como profissionais, mas também as IES onde trabalham e a história desses cursos no cenário brasileiro.

Sacristán (1995) afirma que o conceito de profissionalidade docente é o conjunto de comportamentos, conhecimentos, destrezas, virtudes e valores que constituem a especificidade de ser professor. Para o autor, tal conceito está em constante elaboração, "devendo ser analisado em função do momento histórico concreto e da realidade social que o conhecimento escolar pretende legitimar, em suma, tem que ser contextualizado" (Sacristán, 1995, p. 64).

O atual cenário educacional brasileiro chama atenção pelos inúmeros problemas que enfrenta historicamente: o direito e o acesso à educação, a fragilidade das políticas públicas, a desigualdade entre a oferta de vagas em instituições educacionais nos estados e a qualidade do ensino e da aprendizagem, assim como outros pontos críticos com que nos deparamos no cotidiano.

Entretanto, consideramos que os cursos lato sensu não têm recebido a atenção que merecem, já que representam uma possibilidade de atualização dos profissionais em diversas áreas do conhecimento.

Assim, devemos antes situar esse docente em seu contexto, apresentando um breve histórico do ensino superior até o momento atual da pós-graduação lato sensu, para conhecer melhor seus atores. Berbel (1994, p. 11) reforça essa ideia:

Assim é que, num campo particular da atividade humana, o da educação, e, mais especificamente, num de seus aspectos, o do preparo pedagógico do professor de $3^{\circ} \mathrm{grau}$, no final do século $\mathrm{XX}$, no Brasil, é possível identificar elementos constitutivos da história passada e seus reflexos no presente, configurando uma porção da realidade social construída pelo homem e que, de certa forma, determinam situação do futuro. 
A universidade do século XX era essencialmente voltada para a pesquisa e o ensino, atendendo ao pressuposto de que essa simbiose era condição para manter vivos o espírito da descoberta e a permanente evolução do pensamento.

Esse ideal sofreu muitas interferências no decorrer dos anos em diversos países, de acordo com os fatos históricos, mas ainda segue sendo uma referência no ensino superior, apesar de certas contradições e desafios colocados pela lógica de mercado atual.

No Brasil, esse ideal teve início em 1808, com a instalação da primeira escola de nível superior, na Bahia, e o curso de Medicina trazido pela coroa portuguesa. Até então, as iniciativas na área da educação haviam sido lideradas pelos jesuítas e voltadas à catequese religiosa. Os altos funcionários da Igreja e da coroa e os filhos dos grandes latifundiários precisavam ir à Europa para obter formação universitária, sendo o destino principal a cidade de Coimbra, em Portugal.

Portugal dificultava o ensino superior na colônia, principalmente para evitar qualquer crescimento cultural que cultivasse o ensino das ciências, das letras e das artes e, assim, levasse à perda do controle necessário dentro do Brasil. Assim, cedia bolsas de estudo apenas a brasileiros da elite e para poucas carreiras, como matemática, medicina e cirurgia.

Em face da criação da Universidade de São Paulo (USP), em 1934, outras instituições foram surgindo paulatinamente no Brasil, mas de forma não integrada. Entretanto, àquela altura, a evolução do ensino superior brasileiro já estava marcada por uma série de vícios de origem.

A USP reuniu os cursos superiores existentes no estado, integrando-os não pela reitoria ou por mecanismos administrativos, mas pela Faculdade de Filosofia, Ciência e Letras, que seria a instituição de saber fundamental para todas as áreas do conhecimento humano e que compensaria o isolamento das faculdades preexistentes, que eram independentes tanto física quanto academicamente. A proposta baseavase em três vertentes, características já da universidade moderna: ensino, pesquisa e extensão. 
A partir de 1940, com o aumento da demanda por mão de obra num mercado de trabalho em expansão, surgiram instituições educacionais privadas como a Pontifícia Universidade Católica (PUC) e a Fundação Getúlio Vargas (FGV), nas cidades do Rio de Janeiro e de São Paulo, procuradas sobretudo pela classe média e pela elite do país. Só nas décadas seguintes foram fundadas as universidades federais espalhadas pelo Brasil, além das estaduais, municipais e particulares.

Porém, mesmo com esses avanços, a organização da universidade brasileira baseava-se no modelo tradicional de faculdade, inadequado para atender às necessidades do processo de desenvolvimento e às mudanças sociais do país, que se intensificaram na década de 1950.

Para Berbel (1994), essa foi a fase do movimento brasileiro de modernização do modelo de sociedade capitalista, que passava de agrário-exportador a urbanoindustrial. Esse modelo continha elementos decisivos para nortear os rumos da educação em geral e especialmente do ensino superior. A autora revela que:

A lógica predominante na educação do país nesse século [XX] tem
sido a lógica do capital, tanto do ponto de vista da preparação de
recursos humanos como mão de obra qualificada para todas as áreas,
em que a tecnologia tem sido considerada fator de modernização e
eficiência, quanto do ponto de vista de oportunidades dessa formação,
que pouco a pouco tem sido passada da responsabilidade do setor
público para a iniciativa do setor privado (Berbel, 1994, p. 21).

Para atender a essa fase de desenvolvimento da sociedade brasileira, os cursos de graduação, até então o último nível do ensino, deixaram de suprir as necessidades decorrentes da diversificação dos níveis de conhecimento e das demandas do mercado de trabalho, sempre crescentes.

Tais aspectos aumentaram a procura por cursos lato sensu, intensificada também pelo crescimento significativo da população urbana, pela necessidade de qualificações mais rápidas para o desenvolvimento de áreas específicas, pela exigência de títulos e certificados em determinadas áreas e pelo avanço expressivo da ciência e da tecnologia nos principais setores da economia brasileira.

Assim, em 1961, o Artigo 69 da Lei de Diretrizes e Bases (LDB) formaliza a referência para a modalidade lato sensu, que define que nos estabelecimentos de ensino superior poderiam ser ministrados cursos de especialização, aperfeiçoamento 
ou extensão. Nessa mesma época, a fim de estimular variados núcleos de formação de pessoal qualificado pela concessão de financiamento sob a forma de auxílio ou bolsa de estudo, foram criados o Conselho Nacional de Pesquisas (CNPq) e a Campanha de Aperfeiçoamento do Pessoal em Nível Superior (Capes), que são até hoje importantes impulsionadores do ensino superior.

A clara distinção entre os cursos lato e stricto sensu manifestou-se no Parecer n. 977/1965, pelo relator Newton Sucupira, que regulamentou os cursos de pósgraduação, acentuando sua importância para o progresso do país e enfatizando a ideia de que esses estudos viriam a complementar a formação do pesquisador ou a treinar o especialista altamente qualificado.

O Parecer n. 977/1965 esclareceu que compete ao stricto sensu aprofundar estudos e pesquisas e, ao lato sensu, responder a objetivos práticos profissionais. Para Berbel (1994), pretendia-se que a universidade brasileira conquistasse, por meio de estudos pós-graduados, um caráter verdadeiramente universitário, tornando-se um centro criador de ciência e cultura, além de formar profissionais.

Portanto, em 1965, a universidade brasileira já não era apenas uma instituição simplificada que oferecia as clássicas carreiras liberais. Entre 1950 e 1960, o ensino superior havia quase triplicado os efetivos e apresentava um conjunto de 50 cursos que conferiam capacitação profissional a partir de um aglomerado de faculdades, institutos e serviços.

Toda essa expansão, contudo, não aconteceu de maneira planejada, com a reorganização de seus quadros estruturais ou de seus métodos de ensino. $O$ crescimento se fez pela multiplicação de unidades, pelo acréscimo de novos campi e pela anexação progressiva de atividades. Infelizmente, esse processo não foi acompanhado de mudança qualitativa ou da necessária reorganização, dando origem a uma crise na universidade brasileira.

Como resposta a essa crise e às diversas reivindicações de uma mudança institucional, em 1968, organizou-se um Grupo de Trabalho - a partir do Decreto n. 62.937 - encarregado de estudar, em caráter de urgência, as medidas que deveriam ser tomadas. Esse grupo tinha a tarefa de pesquisar uma reforma da universidade brasileira a partir de um repertório de soluções realistas e de medidas operacionais 
que permitissem racionalizar a organização das atividades universitárias, conferindoIhes mais eficiência e produtividade.

Desse estudo originou-se a Reforma Universitária de 1968, que pretendia assegurar às universidades uma sólida autonomia didático-científica, disciplinar, administrativa e financeira a partir de um modelo organizacional único para instituições públicas ou privadas. Em seu relatório final, ficou registrado que essa crise sensibilizou diferentes setores da sociedade, que não puderam deixar de "exigir do Governo uma ação eficaz que enfrentasse de imediato o problema da reforma universitária, convertida numa das urgências nacionais" (Brasil, 1968, p. 17).

Entre as principais mudanças da Reforma de 1968, podemos citar: o fim do regime de cátedras, a adoção do sistema de vestibular unificado para o ingresso na universidade e a matrícula por regime de créditos.

Os cursos de ensino superior continuaram a crescer dos anos 1970 até o início dos 1990. Para Berbel (1994), isso favoreceu o mercado empresarial escolar, que passou a se beneficiar financeiramente, mas também, de certa forma, comprometeu a qualidade do sistema educacional na maior parte das instituições de ensino superior (IES), desde o processo seletivo até a preparação dos docentes, assim como as condições profissionais para a formação consistente dos alunos.

Bosi (2007) chama esse processo de "mercantilização da educação superior" e o considera um aspecto central da atual precarização do trabalho docente, com consequências preocupantes:

O crescimento da força de trabalho docente ocorrido, principalmente, no setor privado e em novas universidades estaduais, em que as condições de trabalho e de contrato existentes geralmente são precárias, a mercantilização das atividades de ensino, pesquisa e extensão nas IES públicas e a adoção de critérios exclusivamente quantitativistas para a avaliação da produção do trabalho docente e suas consequências (Bosi, 2007, p. 1503).

O autor esclarece que, a partir da década de 1970, o Brasil passou a enfrentar desde o barateamento da mão de obra, por meio da reestruturação dos processos de trabalho e de produção de mercadorias, até a transferência significativa dos serviços públicos para a esfera privada. Como resultado, seguiu-se uma série de reformas 
estruturais, baseadas na desregulamentação dos mercados, na abertura comercial e financeira, na privatização do setor público e na redução do Estado.

Bosi (2007) ilustra essa privatização do setor público com dados do Ministério da Educação (MEC) e do Instituto Nacional de Estudos e Pesquisas Educacionais Anísio Teixeira (INEP). Até 1980, cada setor (público e privado) detinha 50\% das matrículas nas IES. Já em 1990, a porcentagem era de 70\% nas IES privadas e 30\% nas públicas. O mesmo se verifica com o número de docentes: em 1980, havia 60.037 $(54,6 \%)$ nas IES públicas e 49.451 (45,4\%) nas privadas, evoluindo em 2004, respectivamente, para $93.800(33,6 \%)$ e $185.258(66,7 \%)$.

Quanto à flexibilização dos contratos trabalhistas, dados do INEP (Brasil, $2005^{1}$ apud Bosi, 2007, p. 1508) mostram que, já nessa época, apenas $16,9 \%$ dos professores se enquadravam em regime de dedicação exclusiva, sendo que nas IES privadas quase $70 \%$ dos docentes trabalhavam como horistas. ${ }^{2}$ Para o autor, esses foram os principais reflexos de um sistema educacional "produtivista", que, de certa forma, comprometeu drasticamente a autonomia intelectual de docentes e alunos.

Diante dessa situação, em 1996, foi sancionada a LDB n. 9.394, que definiu e regularizou o sistema educacional brasileiro com base nos princípios da Constituição e sofreu sua última atualização em 2013, com a Lei n. 12.796. Essa lei concorreu para a reestruturação do ensino superior com a proposta dos currículos orientados para o desenvolvimento de competências. Em seu artigo 52, cita a obrigatoriedade da composição mínima do quadro de docentes das IES por mestres e doutores.

Após a LDB/1996, expandiu-se ainda mais o ensino superior no setor privado, estimulado pelo governo com a liberalização dos serviços educacionais e a isenção fiscal, constituindo um contínuo processo de privatização, com a introdução das IES privadas no mercado de ações do capital. Assim, permitiram-se a existência e o funcionamento de instituições de ensino com fins lucrativos, adeptas da lógica mercantilista (Chaves, 2010).

\footnotetext{
${ }^{1}$ BRASIL. Ministério da Educação. Instituto Nacional de Estudos e Pesquisas Educacionais. Cadastro Nacional de Docentes da Educação Superior. Brasília, DF: MEC/INEP, 2005. Disponível em: $<$ http://www.inep.gov.br/>. Acesso em: 27 abr. 2006.

${ }^{2}$ Termo que designa os docentes contratados por determinada carga horária semanal ou mensal.
} 
As iniciativas privadas no ensino superior expandiram-se ao perceber na profissionalização um mercado bastante lucrativo. De outro lado, cresceu a preocupação com a natureza universitária, com o aumento da diversidade de funções, com a massificação do ensino e com a própria reprodutibilidade e a qualidade do ensino e da aprendizagem.

Esse processo de expansão da iniciativa privada se intensificou e se desenvolve até os dias de hoje. Chaves (2010, p. 491) explica esse cenário:

\begin{abstract}
Desde 2007, o processo de mercantilização do ensino superior brasileiro vem adquirindo novos contornos. Observa-se um forte movimento de compra e venda de IES no setor privado. Além das fusões, [...] "as empresas de ensino" agora abrem o capital na bolsa de valores, com a promessa de expansão ainda mais intensa e incontrolável. [...] é importante ressaltar que grande parte do capital dessas empresas é oriunda de grupos estrangeiros, em especial, de bancos de investimentos norte-americanos, que encontraram, nesse setor, um mercado muito favorável ao aumento de seus lucros.
\end{abstract}

Em decorrência disso, assistimos hoje à formação de grandes grupos empresariais que conseguem reduzir custos operacionais e aumentar cada vez mais suas margens de lucro, o que revela uma forte tendência à formação de oligopólios (pequeno número de grandes empresas que atuam em determinado segmento de mercado), que, por sua vez, tendem a aumentar o controle da educação superior no Brasil pelo mercado.

Nessa perspectiva, Chamlian (2006) afirma que agora concorrem duas visões de universidade: uma ligada à concepção original, com uma forte articulação entre ensino e pesquisa e de caráter mais cultural, e outra relacionada às evoluções da conjuntura socioeconômica, demandando profissionais mais qualificados e com formação mais flexível, o que enseja certas contradições e confrontos no ensino superior.

Para a autora, o grande desafio do ensino superior é "preservar o respeito à ideia de Universidade: o 'ethos' acadêmico de indissociabilidade entre ensino e pesquisa, que requer um professor autônomo [...]" (Chamlian, 2006, p. 89).

Entretanto, é importante compreender melhor como é definido hoje o ensino superior no Brasil. Segundo o MEC ([s.d.]b), o ensino superior pode ser oferecido por 
universidades, centros universitários, faculdades, institutos superiores ou centros de educação tecnológica. Já o aluno pode optar por três tipos de graduação: bacharelado, licenciatura ou formação tecnológica. E os cursos de pós-graduação são divididos entre lato sensu (especialização e MBA) e stricto sensu (mestrado e doutorado). A expressão latina lato sensu significa "em sentido amplo", em contraposição ao significado estrito do stricto sensu.

No que se tange ao formato, há três tipos de cursos: os presenciais, nos quais o aluno deve ter frequência em pelo menos $75 \%$ das aulas, os semipresenciais ou híbridos, que combinam aulas em sala de aula e à distância, e os que são totalmente à distância (os chamados EAD, ou ensino a distância).

Nas instituições públicas, o ensino superior de graduação e pós-graduação stricto sensu é gratuito, por força de norma constitucional, enquanto, na pósgraduação lato sensu, as instituições cobram mensalidades dos alunos, o que é objeto de crítica por parte de alguns profissionais da educação.

No que se refere às instituições privadas, há cobrança de mensalidades tanto na graduação como na pós-graduação para qualquer titulação oferecida. Considerando que existe uma grande variedade de custos entre as IES, bem como entre os diversos cursos oferecidos por uma mesma IES, alunos de classes econômicas menos favorecidas passaram a ingressar em cursos de ensino superior que têm preços mais acessíveis e são oferecidos por algumas dessas instituições.

Apesar de haver programas de incentivo (bolsas de estudo) oferecidos pelo governo federal (Fundo de Financiamento Estudantil - FIES e Programa Universidade para Todos - PROUNI) e pelos governos estaduais, eles não abrangem os cursos lato sensu, o que muitas vezes dificulta o acesso de alunos interessados em se especializar e pode até impedir os já matriculados de concluir seu curso.

O Censo da Educação Superior 2014, realizado pelo INEP (2016) em parceria com o MEC (incluindo todos os tipos de curso do ensino superior), aponta que o Brasil tem 2.368 mil IES (sendo 12,6\% públicas e $87,4 \%$ privadas) e mais de 7,8 milhões de estudantes matriculados. Entre 2003 e 2014, as matrículas na educação superior aumentaram $96,5 \%$, mas ainda correspondem a menos de $4 \%$ da população. Ou seja, 
apesar da grande expansão do ensino superior nas últimas décadas, ele ainda não é acessível a todos os brasileiros.

Os dados também mostram que tende a crescer o número de estudantes, instituições e docentes (MEC, [s.d.]b). Em 2013, houve 3,8\% mais estudantes inscritos no ensino superior do que em 2012, sendo $1,9 \%$ na rede pública e $4,5 \%$ na privada. $\mathrm{Na}$ cidade de São Paulo, a proporção é de cinco matriculados na rede privada para cada aluno da rede pública.

Ainda segundo o INEP (2016), a maioria dos docentes que lecionam no ensino superior (rede pública e privada) são do sexo masculino, sendo que a média geral das idades é de 37 anos em instituições públicas e de 35 nas privadas. A titulação docente mais encontrada na rede pública é o doutorado, enquanto na privada é o mestrado.

Em 2014, havia 383.386 mil docentes em exercício (INEP, 2016), dos quais $57,5 \%$ tinham vínculo com IES privadas e $42,5 \%$ com IES públicas. Nas redes públicas, $82,9 \%$ dos docentes têm contrato de trabalho de regime de tempo integral, enquanto na rede privada esse percentual é de apenas $24,4 \%$, com $40,4 \%$ dos professores contratados em tempo parcial e $35,2 \%$ contratados como horistas. Em cursos lato sensu, encontramos uma alta porcentagem de professores horistas, devido à própria natureza e organização curricular desses cursos.

A Secretaria de Regulação e Supervisão da Educação Superior (SERES), órgão do MEC, é a unidade responsável por garantir que a legislação educacional seja cumprida para melhorar a qualidade dos cursos superiores no país. Já para avaliar a qualidade dos cursos de graduação, o INEP e o MEC usam o índice geral de cursos (IGC), divulgado uma vez por ano, logo após a publicação dos resultados do Exame Nacional de Desempenho dos Estudantes (ENADE). Sobre o IGC, diz o MEC ([s.d.]a):

[...] o instrumento é construído com base numa média ponderada das notas dos cursos de graduação e pós-graduação de cada instituição. Assim, sintetiza num único indicador a qualidade de todos os cursos de graduação, mestrado e doutorado da mesma instituição de ensino. O IGC é divulgado anualmente pelo INEP/MEC, imediatamente após a divulgação dos resultados do ENADE. 
Nesse panorama atual do sistema educacional brasileiro, encontram-se os cursos de pós-graduação lato sensu, que são objeto deste estudo.

\subsection{Os cursos de pós-graduação lato sensu}

Segundo o MEC ([s.d.]a), os cursos de pós-graduação lato sensu devem ter duração mínima de 360 horas e culminar com uma monografia ou um trabalho de conclusão de curso. Só podem se matricular nesses cursos aqueles que têm diploma de curso superior.

Como vimos no histórico do ensino superior, os cursos lato sensu surgem nos anos 1960 principalmente para dar suporte ao progresso do país, assim como ao rápido desenvolvimento científico e tecnológico, que demandava a formação de profissionais especializados em carreiras e áreas que a graduação ou os programas de stricto sensu não atendiam.

Houve tentativas de regulamentar esses cursos, mas até hoje não existe uma legislação que respalde eficazmente o desempenho dessas atividades, o que pode comprometer todo o processo de ensino e de aprendizagem.

O órgão que estabelece as normas para o funcionamento de cursos de pósgraduação lato sensu em nível de especialização é o MEC. Sobre essa regulamentação, o artigo $1^{\circ}$ da Resolução CNE/CES n. 1, de 8 de junho de 2007 (Brasil, 2007), afirma que "os cursos de pós-graduação lato sensu oferecidos por instituições de educação superior devidamente credenciadas independem de autorização, reconhecimento e renovação de reconhecimento".

Já na página "Lato Sensu - Saiba Mais" do website do MEC ([s.d.]b), encontramos a complementação de que as instituições de ensino superior credenciadas podem ser consultadas no cadastro do e-MEC, ${ }^{3}$ reforçando que os cursos lato sensu podem ser oferecidos sem autorização prévia nem reconhecimento posterior das áreas em que oferecem graduação.

\footnotetext{
${ }^{3}$ Portal que dá informações sobre as instituições de educação superior credenciadas e os cursos superiores autorizados (MEC, [s.d.]b).
} 
Podemos verificar que as disposições da Resolução CNE/CES n. 1/2007 estabelecem para os cursos lato sensu apenas parâmetros básicos tais como carga horária, emissão do certificado e constituição de corpo docente. A averiguação e o acompanhamento por parte do MEC são realizados nas IES, mas sem preocupação específica com os cursos lato sensu. Assim, as IES ficam livres para criar, administrar e desenvolver seus próprios mecanismos internos de avaliação, o que pode gerar diversas interpretações e impactos no processo de ensino e aprendizagem.

$\mathrm{Na}$ prática, os alunos dos cursos lato sensu fazem avaliações informais, aplicadas a critério do próprio docente, imediatamente após o término do módulo ou da disciplina. Entretanto, essencialmente fragmentadas, essas avaliações dão ao coordenador do curso um retorno apenas circunstancial.

Quando as expectativas dos alunos com relação a alguma disciplina não são concretizadas, eles solicitam ao coordenador que substitua o respectivo professor. Quando, ao contrário, essas expectativas são atendidas ou superadas, os próprios alunos chegam a pedir para que o docente conduza outras disciplinas do curso. Embora esse tipo espontâneo de avaliação enseje alguma verificação da qualidade do docente e da disciplina, não garante por si só um acompanhamento contínuo e consistente, que permita avaliar os saberes pedagógicos dos docentes.

O MEC ([s.d.]b) também define que os cursos lato sensu devem ter pelo menos $50 \%$ dos professores com título de mestre ou de doutor obtido em programa de pósgraduação stricto sensu reconhecido. Os demais devem apresentar, no mínimo, formação em nível de especialização ou técnico-profissional obtida em instituição reconhecida.

Todavia, notamos que o espaço acadêmico para os especialistas, que são parte considerável do corpo docente do lato sensu, será cada vez mais restrito, pois a meta 13 do Plano Nacional de Educação (PNE) (MEC, [s.d.]b) prevê:

[...] elevar a qualidade da educação superior e ampliar a proporção de mestres e doutores do corpo docente em efetivo exercício no conjunto do sistema de educação superior para $75 \%$ (setenta e cinco por cento), sendo, do total, no mínimo, $35 \%$ (trinta e cinco por cento) doutores (MEC, [s.d.]b, p. 13). 
Em 20 metas, o Plano Nacional de Educação (PNE) determina as diretrizes e estratégias para a política educacional dos dez anos seguintes (2014-2024) e propõe um conjunto de metas para o ensino superior. Outras ações para o desenvolvimento estão sendo conduzidas para aprimorar a qualidade do ensino superior no Brasil, mas persiste uma grande necessidade de fortalecer as políticas públicas que incentivam e acompanham as instituições de ensino.

Devemos também considerar o impacto do regime de contratação dos docentes que lecionam nas IES e que interfere diretamente no processo de ensino e aprendizagem, pois, se trabalhassem com dedicação integral e exclusiva, poderiam planejar de forma mais eficiente e atualizar seus saberes docentes, assim como dispor de mais disponibilidade para apoio aos alunos e dedicação à pesquisa.

Todos esses dados contextualizam o ensino superior e a pós-graduação lato sensu no Brasil, onde se incluem a IES selecionada da cidade de São Paulo, os docentes pesquisados e os alunos do lato sensu, apresentados a seguir.

\subsection{A IES selecionada, seus docentes e alunos da pós-graduação lato sensu}

A instituição de ensino superior privada selecionada para esta pesquisa fica na cidade de São Paulo e oferece, há quase setenta anos, diversos programas educacionais, que abrangem desde a formação inicial do aluno até o ensino superior.

Pertence a um grupo educacional de mais de 20 unidades espalhadas pela capital paulista voltadas para o ensino superior, com faculdades e centros universitários com mais de 10 mil funcionários. ${ }^{4}$ Esse grupo, por sua vez, faz parte do Sistema Federal de Ensino e tem autonomia para criar e oferecer cursos e programas de educação profissional e tecnológica nas unidades educacionais credenciadas, de acordo com a Lei n. 12.816/2013.

O critério para escolher a instituição foi o fato de ela ser tradicional e de referência nacional em educação profissional em diferentes setores.

\footnotetext{
${ }^{4}$ Entres os funcionários, encontram-se os professores contratados como CLT, mas não os convidados. Dados de outubro de 2016.
} 
A trajetória da instituição tem acompanhado a evolução do mercado de trabalho, intensificada depois da Segunda Guerra Mundial, quando a industrialização e a urbanização ganharam força no país. A instituição percebeu a necessidade de sistematizar esforços para qualificar trabalhadores para ocupar os postos que surgiam em razão da nova configuração da economia.

Ao longo do tempo, consolidou-se como referência na área da educação. $\mathrm{Na}$ rede de unidades próprias, por meio das tecnologias de educação à distância, oferece cursos em diversas áreas do conhecimento e em diversas modalidades, enfatizando a cidadania e a atuação profissional transformadora e valorizando a autonomia, o espírito empreendedor, a inovação e a excelência de profissionais e organizações.

A instituição acompanha as exigências impostas não apenas pelo mercado de trabalho como também pelo governo. Assim, mostra-se comprometida com as metas do PNE e divulga ações como a ampliação do acesso ao ensino superior pelo aumento do número de vagas.

Segundo a meta 12 do PNE (MEC, [s.d.]b), a taxa bruta de matrícula até 2024 na educação superior deve ser elevada para $50 \%$ (em 2013, era de $32,3 \%$ ) e a taxa líquida para 33\% de jovens na faixa etária de 18 a 24 anos (em 2013, era de 16,5\%). Para alcançar essa meta, essa IES aponta a necessidade de o país duplicar, em dez anos, o atual sistema de educação superior, com mais financiamento e melhoria da qualidade da educação.

No nível da educação superior, além dos programas de graduação, a instituição oferece pós-graduação lato sensu. Segundo a IES, os cursos lato sensu têm conteúdo teórico e prático e são criados a partir das necessidades e tendências do mercado de trabalho.

Em 1993, foi lançado o primeiro programa lato sensu na IES, que foi gradativamente expandido com o passar dos anos. Segundo seus relatórios de fechamento, em 2015, foram atendidos mais de 7 mil alunos.

A IES selecionada afirma que não existe uma avaliação externa específica e exclusiva dos cursos lato sensu da unidade selecionada. Todos os seus cursos são avaliados no recredenciamento feito pelo MEC junto ao centro universitário do grupo 
a que ela pertence. Além disso, existe uma comissão própria de avaliação (CPA), que dispõe de um regulamento interno baseado na legislação e com as normas vigentes regidas pelo Sistema Federal de Ensino, que trabalha para identificar tanto as qualidades da instituição como os desafios que ela enfrenta. Identificados tais aspectos, a CPA fornece informações para a implementação de melhorias educacionais, administrativas e infraestruturais.

Outro motivo para a escolha da IES foi seu ideal educativo, que desloca a ênfase do ensino para a aprendizagem e entende a educação como um processo em que o aluno está envolvido ativamente na construção das próprias competências.

A partir do tripé ensino, pesquisa e extensão, a instituição afirma que estimula práticas pedagógicas inovadoras pela aplicação de metodologias mais participativas, estruturadas na prática e baseadas em situações reais de trabalho, com o uso de estudos de caso, pesquisa, solução de problemas, projetos e outras estratégias.

Para atender a esse posicionamento, a IES depende de educadores bem formados que proporcionem ambientes e situações adequadas para que o aluno atue e aprenda como protagonista do processo de aprendizagem.

Atualmente, é grande o desafio de formar profissionais com os requisitos da contemporaneidade. Esses profissionais devem adaptar-se às exigências de uma sociedade cuja produção se reorganiza constantemente, usando novas tecnologias que mudam em ritmo acelerado e que, por sua vez, determinam novas exigências aos trabalhadores.

Assim, esses profissionais devem ser capazes de inovar, adquirir e construir conhecimentos com rapidez, empreender seu trabalho, agir com autonomia e responsabilidade, tomar iniciativas, resolver problemas de modo criativo, ter pensamento sistêmico e boa capacidade de comunicação em várias linguagens e tecnologias.

De acordo com a IES, os docentes dos cursos lato sensu planejam suas aulas sequencialmente, estimulam a aprendizagem dos alunos, promovem a reflexão, sintetizam, reformulam, criticam e avaliam, atuando como mediadores e orientadores, e não apenas como transmissores de conhecimentos e experiências profissionais. 
Esse é o terceiro e principal motivo da escolha da instituição, uma vez que é coerente com a visão dos saberes pedagógicos proposta nesta pesquisa.

Os docentes são admitidos na IES selecionada de duas formas. Uma é a partir de um processo seletivo divulgado publicamente, que começa com uma triagem de currículos, seguida de redação, entrevista e aula-teste, para concorrer à contratação em regime de trabalho previsto na Consolidação de Leis do Trabalho (CLT). A carga horária de dedicação é definida conforme a necessidade da própria instituição e das disciplinas oferecidas e pode ser por horas semanais (tempo parcial) ou com dedicação exclusiva (tempo integral).

A outra forma é a contratação por tempo determinado, chamada carta-convite, que é específica para determinada disciplina do curso lato sensu, com base no número de horas necessárias para o desenvolvimento do programa dessa disciplina. Nesse caso, o docente é convidado e contratado por tempo determinado, como pessoa física ou jurídica.

Esse vínculo temporário (por carta-convite) é o mais encontrado nos cursos lato sensu na IES, que somam uma média de 360 horas, distribuídas em três semestres, organizados, em média, entre 12 a 15 disciplinas (4 a 5 por semestre), com 16 a 40 horas.

Para a IES selecionada e outras com perfil semelhante, torna-se financeiramente inviável contar com um docente contratado por CLT para cada disciplina de seus cursos lato sensu, além do fato de que muitos desses docentes são especialistas numa área de conhecimento específica, podendo lecionar apenas em um curso de lato sensu oferecido pela IES.

O perfil dos docentes do lato sensu é detalhado no Capítulo 3, a partir da amostra dos cursos lato sensu da IES selecionada: Responsabilidade Social Empresarial e Sustentabilidade, Gestão Estratégica de Pessoas e Marketing de Varejo.

Independentemente da forma de contratação, um critério importante é averiguar se esses docentes têm os saberes necessários a sua atuação e se se 
identificam com a proposta da IES, com seus planos de curso e seus projetos pedagógicos.

Para conhecer o processo de ensino e aprendizagem, foi preciso conhecer também os alunos do lato sensu. São pessoas com perfis diversos (diferentes idades, gêneros, formações escolares e experiências profissionais), o que lança aos docentes um grande desafio pedagógico:

Uma das consequências mais significativas dessa massificação do ensino é a diversidade dos alunos: a variação social, econômica e cultural, a diferenciação no histórico escolar e dos saberes e competências anteriormente desenvolvidos, a divergência de motivações e expectativas profissionais, as diferenças individuais e os traços de personalidade, sejam por suas características, sejam pelas experiências de vida. É nesse mix cultural, nesse contexto cada vez mais heterogêneo, que os alunos e professores transitam e participam do processo de aprendizagem para a formação profissional (Gaeta; Masetto, 2013, p. 35).

Um traço marcante do curso lato sensu (e de todo o ensino superior) é a presença digital, constantemente utilizada pelos alunos de todas as idades. Eles procuram respostas imediatas a seus questionamentos, a partir do fácil acesso a informações pela internet, informações essas nem sempre confiáveis e muitas vezes superficiais e fragmentadas.

Esses alunos têm em comum o objetivo de buscar a atualização de seus próprios saberes para uma melhor atuação no mercado de trabalho. Por isso, devem ser vistos como sujeitos adultos, conscientes das próprias necessidades, com diferentes interesses e projetos. Em sua grande maioria, buscam cursos lato sensu para obter uma especialização em sua profissão e esperam se atualizar mediante a experiência profissional e os conhecimentos específicos dos docentes, sempre com vistas a aplicar essa aprendizagem em seu cotidiano.

Para isso, é fundamental que o docente saiba articular os saberes da disciplina (conhecimento de sua área de estudo), os experienciais (relativos ao seu desenvolvimento profissional) e os pedagógicos (conhecimento e prática educacionais), assunto discutido no Capítulo 2. 


\section{CAPÍTULO 2}

\section{OS SABERES PEDAGÓGICOS DOCENTES}

\subsection{A composição dos saberes docentes}

Situados o cenário atual do ensino superior brasileiro, os cursos lato sensu, a IES selecionada, e o perfil dos docentes e alunos, analisamos agora as expectativas sobre os saberes docentes, para compreender os saberes pedagógicos, que foram investigados na pesquisa de campo.

Consideramos que a profissão docente abrange uma diversidade de significados, já que não é uma atividade simples, que depende apenas de conhecimentos e habilidades técnicas. Além do aspecto profissional, exige um intenso envolvimento pessoal, porquanto se fundamenta essencialmente no relacionamento com pessoas.

Nessa perspectiva, a tentativa de entender a própria identidade profissional se estende por toda a carreira docente, que, por sua vez, passou a ser questionada pelos profissionais do ensino superior, inclusive pelo próprio docente, há aproximadamente duas décadas.

Ser docente no ensino superior não pode ser confundido com "a boa vontade de dar algumas horas de meu tempo para ajudar os alunos de um curso"; não pode ser confundido com "um bico que vou fazer para melhorar meu salário"; não pode ser confundido com a possível capacidade de comunicar algumas experiências profissionais aos alunos (Gaeta; Masetto, 2013, p. 97).

Segundo Tardif (2002), há uma relação instável entre os professores e seus saberes que se constitui como um campo de pesquisa relativamente novo e pouco explorado pelas ciências da educação. Assim, os saberes docentes têm uma posição estratégica entre os saberes sociais, compostos por variadas fontes, inclusive conhecimentos e habilidades mobilizados diariamente nas salas de aulas para a consecução das atividades práticas.

Se chamamos de "saberes sociais" o conjunto de saberes de que dispõe uma sociedade e de "educação" o conjunto dos processos de formação e de aprendizagem elaborados socialmente e destinados a instruir os membros da sociedade com base nesses saberes, então é evidente que os grupos de educadores, os corpos docentes que 
realizam efetivamente esses processos educativos no âmbito do sistema de formação em vigor, são chamados, de uma maneira ou de outra, a definir sua prática em relação aos saberes que possuem e transmitem (Tardif, 2002, p. 23).

Esses saberes são sociais, pois se manifestam a partir da relação do professor com alunos e colegas docentes e são modificados, incorporados e adaptados em função do momento e de determinadas fases da trajetória profissional.

O autor explica que os saberes docentes são temporais, por derivar do contexto da história de vida e da carreira profissional percorrida - antes mesmo de ensinar, o professor terá vivido no ambiente de sala de aula certas crenças e representações acerca do ensino. Essas crenças e representações vivenciadas como aluno são decisivas para o desenvolvimento de sua prática profissional durante os primeiros anos de trabalho.

Os saberes docentes são igualmente plurais, por provir de diversas fontes: de sua cultura escolar anterior, dos conhecimentos disciplinares adquiridos na universidade, das referências pedagógicas compartilhadas e das diversas experiências de trabalho. Além de sociais e plurais, os saberes são heterogêneos não por formar um repertório de conhecimentos unificado, mas por serem ecléticos e sincréticos.

Apesar de buscar identificar os diversos saberes que afetam a prática docente, sabemos que eles são sempre atravessados pela história de vida do docente e variam de acordo com suas emoções, sua personalidade e sua cultura. Portanto, são subjetivos e indissociáveis de sua identidade, de suas experiências e situações de trabalho. O docente constrói e aplica os saberes de acordo com determinada situação presenciada, na qual eles ganham sentido de fato.

Tardif (2002) classifica os saberes docentes em grupos interdependentes: pedagógicos, disciplinares, curriculares e experienciais. Embora sejam interdependentes e se influenciem mutuamente, estudam-se nesta pesquisa os saberes pedagógicos - também chamados por Tardif (2002) de saberes da formação profissional -, compostos pelo conhecimento e pelas habilidades e práticas das ciências da educação e da pedagogia, que deveriam fazer parte da formação inicial de todos os docentes. São os saberes destinados à formação científica da docência 
que, quando incorporados, podem se transformar em metodologias práticas de aprendizagem:

Os saberes pedagógicos apresentam-se como [...] concepções provenientes de reflexões sobre a prática educativa no sentido amplo do termo, reflexões racionais e normativas que conduzem a sistemas mais ou menos coerentes de representação e de orientação da atividade educativa (Tardif, 2002, p. 27).

Sincronicamente, os saberes disciplinares reúnem os saberes sociais definidos e selecionados pela instituição educacional, concernentes aos diversos campos do conhecimento, tais como finanças ou gestão de pessoas. Tardif (2002) afirma que os saberes disciplinares são os que surgem da tradição cultural e são transmitidos em geral nos cursos de graduação em instituições educacionais.

Com base em discursos, objetivos e métodos categorizados pelas instituições escolares, apresentados na forma de programas que os docentes precisam conhecer e aplicar, encontramos os saberes curriculares (Tardif, 2002), tratados-neste estudo em conjunto com os saberes disciplinares.

Segundo Masetto (2014), também é esperado que esses saberes incluam pesquisas no campo específico de conhecimento. A associação entre docência e pesquisa não pode ser esquecida, mas sim estimulada pelas IES e conduzida pelo docente por meio de estudos e de reflexões críticas sobre temas teóricos ou experiências pessoais que reorganizam os conhecimentos, reconstruindo-os e dandoIhes novo significado:

Entendemos por pesquisa os trabalhos específicos preparados pelos professores para serem apresentados em congressos e simpósios, explorando aspectos teóricos ou relatando criticamente suas experiências pessoais na área profissional ou de ensino, ou discutindo novos aspectos de algum assunto mais atual. Entendemos por pesquisa a redação de capítulos de livros, artigos para revistas especializadas etc. Docentes em fase de mestrado ou doutorado também realizam pesquisas, que certamente serão incorporadas a sua docência. [...] Essa produção científica também enriquecerá o domínio de conhecimento que se espera de um docente de ensino superior (Masetto, 2014, p. 19).

Nos programas de pós-graduação stricto sensu, percebemos a valorização da pesquisa, relegando a formação para a docência. Já nos cursos lato sensu, geralmente são apenas os docentes contratados em regime de tempo parcial ou 
integral (que são a minoria) que fazem pesquisa, estimulada pela IES. Nos dois casos, constatamos uma desvalorização da profissão docente.

Entrelaçados aos saberes pedagógicos e disciplinares, encontram-se os saberes experienciais, que são desenvolvidos na prática profissional, incorporados como habilidades à experiência individual e coletiva.

Em suma, o professor ideal é alguém que deve conhecer sua matéria, sua disciplina e seu programa, além de possuir certos conhecimentos relativos às ciências da educação e à pedagogia e desenvolver um saber prático baseado em sua experiência cotidiana com os alunos (Tardif, 2002, p. 29).

Seja em uma área específica do conhecimento ou na própria docência, os saberes experienciais são aqueles desenvolvidos na prática docente. Eles emergem da experiência e são validados no trabalho cotidiano e no conhecimento do meio.

Baseada em sua própria experiência no ensino de didática em cursos de licenciatura e em pesquisas sobre a formação inicial e contínua de professores, Pimenta (2007) propõe a reflexão sobre a identidade docente e a ressignificação dos processos formativos a partir da reconsideração dos saberes necessários à docência, analisando a prática pedagógica e profissional.

A autora caracteriza os saberes docentes de forma similar a Tardif (2002), agrupando-os como saberes pedagógicos, do conhecimento e da experiência. Afirma que os saberes pedagógicos são os relativos à prática educacional e que devem tomar a prática dos formandos como ponto de partida e de chegada, indo além dos esquemas apriorísticos das ciências da educação, pois se produzem na ação. Conhecer educação e pedagogia não leva automaticamente aos saberes pedagógicos, pois estes só se constituem na prática, que os confronta e reelabora.

Os saberes do conhecimento implicam saber discutir os conhecimentos específicos no contexto da contemporaneidade para a formação dos alunos e saber transmitir as informações da disciplina da especialidade dos docentes.

Já os saberes da experiência são os construídos pela vivência do docente como aluno, associados a referências de bons professores que foram significativos 
em sua vida, além da própria atividade docente que exerce no decorrer da carreira, que alimenta um processo constante de reflexão sobre essa prática.

Complementando as propostas de Tardif (2002) e Pimenta (2007), Masetto (2014) não designa as exigências da docência no ensino superior como saberes, mas como competências. O autor entende que o professor deve ser competente em determinada área de conhecimento, o que envolve conhecimentos básicos nessa área e experiência profissional, assim como a constante atualização em cursos de aperfeiçoamento, especializações e congressos e o domínio da área pela pesquisa.

Masetto (2014) afirma que a docência exige do profissional também o domínio da área pedagógica - a seu ver, o aspecto mais frágil dos professores universitários. A competência pedagógica divide-se entre o próprio conceito de processo de ensino e aprendizagem, o professor como criador e gestor do currículo, a compreensão da relação professor-aluno e aluno-aluno no processo e a teoria e a prática da tecnologia educacional. O autor considera que, no ensino superior, é comum os professores lecionarem duas ou três disciplinas num curso sem construir entre elas um nexo explícito, situação ainda mais recorrente no lato sensu.

De acordo com o autor, a terceira competência docente é o exercício da dimensão política, pois, além de ser um cidadão com uma visão da sociedade, o professor pratica a reflexão crítica nas aulas, conciliando os aspectos técnico e ético.

Uma quarta abordagem correlata é a de Vasconcelos (2014), que contempla diferentes aspectos da competência de um educador para que seja considerado um profissional completo e com formação adequada para o exercício da função docente: formação técnico-científica (domínio técnico do conteúdo a ministrar); formação prática (conhecimento da prática profissional para a qual se preparam os alunos); formação política (ver a educação como um ato político e intencional, do qual se exigem ética e competência); e formação pedagógica (voltada e construída no fazer pedagógico cotidiano, em sala de aula, de modo não ocasional, mas desenhado metodologicamente).

As importantes conceituações de Tardif (2002), Pimenta (2007), Masetto (2014) e Vasconcelos (2014) concorrem para uma visão mais completa dos saberes docentes considerados necessários à profissão. 


\subsection{Identidade profissional docente}

Para melhor compreender a origem e o desenvolvimento desses saberes, há que considerar a caracterização da identidade profissional docente, que é um campo subjetivo interligado aos saberes. O docente vive um processo de desenvolvimento dos seus saberes em conjunto com a construção da própria identidade.

A identidade é um sistema de relações e representações articuladas de forma complexa, formado histórica e heterogeneamente e que distingue determinado indivíduo dos demais. Embora essa ideia já fosse elaborada historicamente sob diferentes olhares, sofreu uma ruptura na modernidade, engendrando uma nova forma de individualismo e de concepção do sujeito e da identidade, considerada atualmente como subjetividade (Silva, 2009).

Para Hall (2006), foram os avanços da teoria social e das ciências humanas que impactaram as estruturas e os processos centrais das sociedades modernas e concorreram para a chamada "crise de identidade", ou o deslocamento ou a descentração do sujeito, que suscita dúvida e incerteza sobre seu lugar no mundo social e cultural, antes visto como mais coerente e estável.

O autor relaciona os cinco grandes avanços que levaram à formação de um sujeito pós-moderno inacabado e composto por identidades abertas e contraditórias: as traduções do pensamento marxista, a descoberta do inconsciente por Freud, o trabalho do linguista Ferdinand de Saussure, o estudo do filósofo e historiador francês Michel Foucault e o impacto do feminismo. Hall (2006, p. 13) acredita que:

A identidade torna-se uma "celebração móvel" formada e transformada continuamente em relação às formas pelas quais somos representados ou interpelados nos sistemas culturais que nos rodeiam. É definida historicamente, e não biologicamente. O sujeito assume identidades diferentes em diferentes momentos, identidades que são unificadas ao redor de um "eu" coerente.

A noção de identidade é estudada por diversos campos, especialmente a psicologia, a economia e a sociologia. Ferreira (1996, p. 312) entende que o conceito tem oscilado entre um polo individual e um coletivo e sugere que "a conciliação destes pontos de vista poderá obter resultados fecundos no estudo das identidades". 
Estudos recentes defendem que a identidade não é um dado imutável e externo, mas um processo dinâmico de construção do sujeito historicamente situado. Esses processos identitários resultam de sucessivas interações ao longo da vida entre o sujeito e diversos meios socioculturais (Silva, 2009).

O termo identidade assume diversos significados, porém, para Melucci (2004), sempre inclui três elementos: a existência de um sujeito que se conserva no tempo (sua continuidade); a noção de unidade com limites entre um sujeito e outro (sua delimitação); e a capacidade de reconhecer-se e de ser reconhecido.

Assim, a identidade define nossa capacidade de falar e agir, diferenciando-nos dos outros e nos afirmando a nós mesmos. Portanto, a construção da identidade depende do retorno de informações vindas de outros, embora seja impossível separar rigorosamente os seus aspectos individuais e sociais.

No âmbito individual, ela se apresenta como um processo de aprendizagem que nos conduz à autonomia, que não se encerra com o fim da idade evolutiva, pois nossas diversas vivências nos levam a sempre questionar e reformular nossa identidade. Por outro lado, no âmbito coletivo, a identidade assegura ao grupo ou à sociedade sua continuidade e conservação.

Todavia, hoje vemos nossa identidade como uma ação consciente e resultado da autorreflexão, mais do que como um dado ou uma herança, vivida mais como ação do que como situação. Por esse motivo, Melucci (2004) considera mais adequado o termo identização - por seu caráter processual, autorreflexivo e construído na definição de nós mesmos.

Esse processo de construção comporta a divergência entre a autoidentificação e a identificação fornecida pelo ambiente externo, pois é um sistema de relações e representações sempre em busca de um equilíbrio.

Diante dessa complexidade, relacionam-se os vários polos de identificação, que operam como "eixo fundamental na construção da pessoa ao longo de sua existência". Para analisar esse processo de construção, é necessário considerar a singularidade da história do sujeito e a forma afetiva como ele interage com seus vários contextos (Silva, 2007, p. 236). 
Quanto ao docente, Silva (2009) explica que sua identidade profissional se constrói por meio de suas sucessivas interações com seu meio sociocultural. Ela é heterogênea e composta por diferentes questões inter-relacionadas, como o nível de ensino, a disciplina lecionada, o tempo de serviço, a formação e a experiência profissional docente.

Tais diferenças ganham sentido à medida que consideramos a identidade profissional dos professores como processos identitários que são construídos paulatinamente ao logo da carreira docente, em resultado das diversas reformulações da identidade psicossocial de cada sujeito, para as quais concorrem necessariamente a cultura e o desenvolvimento organizacional de cada escola (Silva, 2009, p. 58).

Consequentemente, a profissão docente como prática social tem um caráter dinâmico. Para Nóvoa (1992, p. 16), "a identidade não é um dado adquirido, não é uma propriedade, não é um produto. A identidade é um lugar de lutas e conflitos, é uma construção de maneiras de ser e de estar na profissão". O autor considera o processo identitário do docente diacrônico e dinâmico, que o leva a sentir-se e a dizerse professor.

A vida familiar e as pessoas significativas também são influências importantes no comportamento do docente com relação ao ensino. Sua experiência escolar anterior e as relações determinantes com professores são importantes modelos para a identidade profissional e os saberes experienciais:

Para atingir fins pedagógicos, o professor também se baseia em juízos provenientes de tradições escolares, pedagógicas e profissionais que ele mesmo assimilou e interiorizou. Ele se baseia, enfim, em sua "experiência vivida" enquanto fonte viva de sentidos a partir da qual o próprio passado the possibilita esclarecer o presente e antecipar o futuro. Valores, normas tradições, experiência vivida são elementos e critérios a partir dos quais o professor emite juízos profissionais (Tardif, 2002, p. 66).

Segundo Esteve (1995), as mudanças sociais e educacionais dos últimos vinte anos tiveram impacto na identidade profissional, especialmente do docente do ensino superior. Algumas dessas mudanças foram: aumento da exigência quanto às atividades dos docentes; inibição de outros agentes de socialização, como a família; surgimento de fontes alternativas de informação; quebra do consenso social do papel da educação; aumento das contradições na atuação docente; mudanças nas expectativas com relação ao sistema educacional; desvalorização social do professor; 
condições de trabalho inadequadas; mudança nas relações professor-aluno e fragmentação do trabalho do professor.

A partir da década de 1980, aliadas à falta de preparação do docente, essas mudanças produziram uma contradição entre o eu real e o eu ideal, ensejando o malestar docente. Esse é um tema recorrente nos depoimentos de professores que vivem no cotidiano a crise de identidade, o que os faz questionar continuamente o verdadeiro significado da profissão.

O docente tem assumido uma posição paradoxal. Muitas vezes, adota um discurso inovador, mas mantém práticas tradicionais, com um ensino ainda centrado em si próprio, a partir de um currículo segmentado em disciplinas e com o processo avaliativo habitual. Todavia, não podemos responsabilizar apenas os docentes pelo modelo adotado pelas IES ou esperado pelos alunos.

O percurso profissional do docente é sujeito a interferências, e sua complexidade apresenta três dimensões: pessoal, afetiva e social-política:

Dimensão pessoal: relaciona-se ao que é a pessoa, aos seus aspectos de personalidade e de temperamento, aos seus talentos e principais dificuldades na vida, às condições de instabilidade e de insegurança que permeiam a sua existência e aos traços dominantes de sua história de vida.

Dimensão afetiva: relaciona-se aos trajetos partilhados com outras pessoas e como foram e são os relacionamentos com a família, com a escola e com os diversos grupos com os quais interage.

Dimensão social-política: relaciona-se aos contextos com os quais já interagiu ou interage, tais como: escolas nas quais trabalha ou trabalhou, profissionais com os quais atuou ou atua, fatores facilitadores da profissão (cooperação, partilha, reflexão coletiva sobre os erros e acertos) e fatores restritivos da profissão (centralização burocrática, falta de estímulo, más condições de trabalho, etc.) (Silva, 2007, p. 247).

Na análise dessas dimensões, constatamos que o contexto e as condições de trabalho dos professores do ensino superior, especialmente do lato sensu, são muito diferentes quanto à forma de ingresso, ao vínculo empregatício e à jornada de trabalho. Esses são fatores críticos que influenciam diretamente essas três dimensões na construção da identidade do docente. Assim, verifica-se uma relação direta entre a identidade docente e os saberes, constatando-se a complexidade do campo de estudo em que se insere esta pesquisa. 
A seguir, analisamos os saberes pedagógicos do docente do ensino superior, para depois investigá-los com os próprios docentes do lato sensu da IES selecionada.

\subsection{Saberes pedagógicos dos docentes do ensino superior}

A partir das conceituações de autores considerados referências na área da educação, agrupamos os saberes dos docentes do ensino superior em três categorias: saberes disciplinares, saberes experienciais e saberes pedagógicos. Esses três tipos se correlacionam na prática docente de forma interdependente e representam os fundamentos do processo de ensino e aprendizagem.

Inicialmente, com base nas considerações e especificidades apresentadas sobre o perfil do docente do ensino superior, constatamos que o saber pedagógico tende a ser o mais frágil, o menos estimulado e desenvolvido na trajetória profissional, em qualquer tipo de formação ou titulação.

Por essa razão, nos dedicamos a investigar esse pressuposto, proceder à pesquisa de campo com docentes de cursos lato sensu, com o objetivo de aprofundar a compreensão sobre seus saberes pedagógicos.

A falta de valorização dos saberes pedagógicos no ensino superior não é recente em nossa história:

Em primeiro lugar, refletir sobre a estrutura organizativa do ensino
superior no Brasil, que desde o seu início (e até hoje...) sempre
privilegiou o domínio de conhecimentos e experiências profissionais
como únicos requisitos para a docência nos cursos superiores.
O embasamento para tal atitude é tanto o modelo de ensino superior
implementado no Brasil (o modelo francês-napoleônico - cursos
profissionalizantes) quanto a crença de que "quem sabe sabe ensinar"
(Masetto, 2003, p. 11).

Com isso, as IES deram prioridade à formação de profissionais a partir de currículos seriados em disciplinas que capacitam à atuação em determinada área. Entretanto, ultimamente, os docentes do ensino superior iniciaram um processo de reflexão sobre a importância dos saberes pedagógicos e seu papel na educação.

Só recentemente os professores universitários começaram a se conscientizar de que seu papel de docente do ensino superior, como 
o exercício de qualquer profissão, exige capacitação própria e específica que não se restringe a ter um diploma de bacharel, ou mesmo de mestre ou doutor, ou ainda apenas o exercício de uma profissão. Exige isso tudo, e competência pedagógica, pois ele é um educador (Masetto, 2003, p. 13).

$\mathrm{Na}$ visão do autor, o ponto mais frágil do professor do ensino superior é o domínio da área pedagógica, desconsiderando-a como elemento essencial de seu trabalho.

E como são caracterizados os saberes pedagógicos dos docentes para o processo de ensino e aprendizagem? Para responder a essa pergunta, organizamos conceitos, estudos e pesquisas sobre o tema nos seguintes tópicos: pedagogia universitária e didática; processo de ensino e aprendizagem de adultos; planejamento pedagógico; prática pedagógica em aula; formação docente; e pesquisas atuais sobre o tema.

\subsubsection{Pedagogia universitária e didática}

É preciso compreender a diferença entre pedagogia universitária e didática, pois ambas são recorrentes na conceituação dos saberes pedagógicos. Enquanto a pedagogia universitária envolve um campo de estudo mais amplo da educação, a didática é uma de suas áreas e aborda uma dimensão concentrada na compreensão do ensino.

Cunha $\left(2003^{5}\right.$ apud Soares, 2009 , p. 321) descreve a pedagogia universitária como "um campo polissêmico de produção e aplicação dos conhecimentos pedagógicos na educação superior". Ela difere da pedagogia pela especificidade do processo de aprendizagem do adulto em sua trajetória formativa.

Para Almeida (2012), a pedagogia é a ciência que tem como objeto os fenômenos educativos e a questão da formação humana, caracterizando uma visão ampla da ciência da educação. Como ciência, comporta os conhecimentos que fundamentam a prática educacional, concebidos pelos saberes pedagógicos

\footnotetext{
${ }^{5}$ CUNHA, M. I. Verbete pedagogia universitária. In: MOROSINI, M. C. Enciclopédia de Pedagogia Universitária. Porto Alegre: RIES/INEP, 2003.
} 
docentes. Já a didática é um campo de estudo que investiga a teoria e a prática do ensino, sendo uma área específica da pedagogia.

Complementares a essas propostas, as contribuições de Pimenta e Anastasiou (2011, p. 86) clarificam essas caracterizações:

Pedagogia tem um significado mais amplo e mais globalizante por ser um campo de conhecimentos sobre a problemática educativa na sua totalidade e historicidade, que tem a sua origem, criação, invenção e renovação na relação teoria-prática da educação como ação educativa. Enquanto a Didática é uma das áreas da Pedagogia que investiga os fundamentos, as condições e os modos de realizar a educação mediante o ensino.

Logo, este estudo sobre os saberes pedagógicos pertence ao campo mais amplo da pedagogia universitária, porque não investiga apenas a dimensão do ensino, mas a complexidade dos saberes pedagógicos dos docentes do lato sensu que influenciam diretamente o processo de ensino e aprendizagem.

Cada vez mais é esperado que esses docentes se tornem profissionais da pedagogia universitária, capazes de lidar com os inúmeros desafios da educação. Masetto (2014) entende que o processo de ensino e aprendizagem no ensino superior está diretamente relacionado à pedagogia, embora se manifeste frequentemente sem a reflexão pedagógica ou então a partir de um modelo pedagógico tradicional de universidade, que ainda não teve sua lógica rompida, mantendo o formato de "aula magistral" (Bireaud, 1995).

Essa questão é reiterada por Pimenta (2007, p. 36):

$\mathrm{Na}$ maioria das instituições de ensino superior, incluindo as universidades, embora seus professores possuam experiência significativa e mesmo anos de estudos em suas áreas específicas, predominam o despreparo e até um desconhecimento científico do que seja o processo de ensino e de aprendizagem, pelo qual passam a ser responsáveis a partir do instante em que ingressam na sala de aula.

Soares (2009) também defende a importância da pedagogia universitária para o docente do ensino superior. As evidências encontradas em seus estudos revelam que muitos docentes são profissionais especialistas em sua área de conhecimento, mas não têm formação pedagógica. 
A responsabilidade do docente é ensinar o conteúdo da disciplina, considerando a interdisciplinaridade do curso e as condições que favoreçam a aprendizagem dos alunos. Certamente, os saberes disciplinares são essenciais, mas, sozinhos, não são suficientes para garantir a aprendizagem dos alunos do ensino superior.

Os saberes pedagógicos caminham interligados e precisam ser articulados na prática docente. Abrangem a teoria e a prática necessárias à atuação de um docente, especialmente do ensino superior:

Os saberes pedagógicos podem colaborar com a prática. Sobretudo se forem mobilizados em decorrência dos problemas que a prática representa, entendendo, assim, a dependência da teoria em relação à prática, pois esta lhe é anterior. Essa anterioridade, no entanto, longe de implicar uma contraposição absoluta à teoria, pressupõe íntima vinculação com ela. Disso decorre um primeiro aspecto por parte dos educadores sobre a sua própria prática, com a contribuição da teoria pedagógica (Pimenta; Anastasiou, 2011, p. 86).

\subsubsection{Processo de ensino e aprendizagem de adultos}

A preocupação do docente do lato sensu com o ensino não se pode restringir à transmissão de informações e experiências, mas deve estender-se ao processo de ensino e aprendizagem dos alunos. É importante compreender que esse é um processo integrado, em que ensino e aprendizagem são complementares.

Para Masetto (2003, p. 20), a missão do docente com o aluno também é a "de aperfeiçoar sua capacidade de pensar; de dar um significado para aquilo que era estudado, de perceber a relação entre o que o professor tratava em aula e sua atividade profissional". Assim, a ênfase passa à aprendizagem ativa dos alunos, que, em geral, se deve à motivação e ao interesse pelo tema, incentivados pelo professor. É preciso compreender como aprende o aluno adulto, diferentemente do modo de aprendizagem das crianças.

$\mathrm{Na}$ pesquisa de Chamlian (2006, p. 87), encontramos uma proposta dos princípios da aprendizagem do adulto: 
1) O adulto aprende quando: a identidade é reforçada; busca a alteridade (definição na posição familiar ou em relação ao parceiro); encontra prazer no aprender; tem demandas internas que são satisfeitas.

2) Fatores internos e externos aos sujeitos influenciam a aprendizagem, tais como: a experiência de vida; o projeto de vida; o reconhecimento de suas qualidades e competências; o gerenciamento do tempo e da energia; as condições mínimas de estabilidade econômica, emocional e física; as condições institucionais de exercício do trabalho.

3) A concepção sobre o conhecimento e sua aquisição influenciam a aprendizagem: processos que criam espaços para a construção de conhecimento compartilhado são facilitadores da aprendizagem; avaliação resultante do processo de autorreflexão é componente importante da aprendizagem.

4) A humanização, as possibilidades de trocas afetivas e espaços de escuta facilitam a aprendizagem. Desse modo: processos que facilitam a apropriação da própria experiência e da experiência dos outros são implicadores e provocam mudanças; a criação de vínculos aluno-aluno e aluno-professor são componentes importantes da aprendizagem do adulto.

5) A figura do professor continua a desempenhar papel importante para o adulto.

De maneira complementar, Aquino (2007) afirma que a aprendizagem se refere à aquisição cognitiva, física e emocional e ao processamento de habilidades e conhecimentos em variadas profundidades. A aprendizagem, portanto, está relacionada ao nível de engajamento com que refletimos sobre o que estamos aprendendo. O autor destaca que, na aprendizagem reflexiva, procuramos entender os porquês e a aplicabilidade de determinado conhecimento para lhe acrescentarmos um significado pessoal.

Assim como Aquino (2007), muitos autores e educadores do ensino superior usam hoje o termo andragogia para designar o estudo da educação voltada para adultos. É uma discussão recente sobre a terminologia, que requer uma análise de conceituação. Nesse sentido, Knowles (1980) foi um dos primeiros a definir a andragogia como a educação centrada no aprendiz, com a responsabilidade da aprendizagem compartilhada entre o professor e o aluno, dando mais independência ao adulto, capaz de julgar o que é importante ou não aprender.

Ainda segundo esse autor, o modelo andragógico estaria fundamentado em suposições básicas ligadas ao modo de aprendizagem de um adulto. 
O primeiro princípio é a necessidade de saber do aprendiz. O adulto precisa entender o porquê do aprendizado e seu ganho no processo. Por isso, é essencial que ele entenda a ação educacional e a aplicabilidade do conhecimento adquirido.

O autoconceito do aprendiz é o segundo princípio afirmado por Knowles (1980). O posicionamento do aluno perante a aprendizagem é de independência ou de autodirecionamento. Isto é, os adultos são responsáveis pelas próprias ações e querem ser vistos dessa forma. Portanto, uma relação professor-aluno que os coloque numa posição passiva pode criar um desconforto. $O$ educador deve criar experiências que ajudem o adulto a passar de aluno dependente a auto-orientado.

O terceiro princípio é considerar a experiência anterior do aprendiz. Os adultos partem de um repertório de experiências mais amplo como base para construir sua aprendizagem. Necessariamente, chegam à aula com muito mais experiência do que uma criança. $\mathrm{O}$ aprendizado será muito mais rico e intenso se cada participante sentir a oportunidade de contribuir na condução do processo.

É importante considerar que a diversidade de experiências enriquece as discussões, mas pode dificultar o planejamento da ação educacional, por se tratar de grupos mais heterogêneos. Também se deve ter em conta que pessoas mais experientes tendem a ser mais fechadas ao novo e mais resistentes a mudanças.

O quarto princípio é a prontidão para aprender. O adulto é mais disposto a aprender o que for necessário para alcançar resultados positivos em situações reais do cotidiano, ou seja, a necessidade engendra prontidão.

A orientação da aprendizagem é o quinto princípio da andragogia. As expectativas do aluno adulto em relação a tempo e currículo são de aplicação imediata, e a orientação deve privilegiar seu desempenho. Diferentemente da criança, que é orientada para o processo de aprendizado em si, o adulto tem o foco na vida, em suas tarefas e em seus problemas. Ele tem disposição para aprender o que dá resultado, preferivelmente imediato. Assim, é fundamental mostrar a aplicação e a utilidade de cada conceito apresentado.

E o sexto princípio é a motivação do adulto para aprender. Ele responde a estímulos externos, mas são os aspectos internos que geram uma maior motivação. 
A verdadeira energia mobilizadora está em fatores subjetivos como satisfação própria, reconhecimento ou autorrealização.

Para Knowles (1980), esses são os elementos constituintes do aprendizado dos adultos, conceitos coerentes com a proposta de Chamlian (2006).

Não discutiremos aqui a terminologia do estudo da aprendizagem dos alunos de cursos lato sensu, mas adotamos a nomenclatura da maior parte das publicações científicas sobre o ensino superior: pedagogia universitária e saberes pedagógicos. Esses conceitos confirmam que a ênfase no processo de aprendizagem do aluno é mais eficaz do que o foco apenas no ensino. Mas precisamos saber que existem consequências desse modelo.

Masetto (2003) afirma que, nesse processo, a organização curricular requer flexibilidade e constante atualização com a interdisciplinaridade e o estudo de temas transversais. Portanto, a contratação dos docentes deve exigir competência pedagógica, para que adotem a metodologia participativa de aula, ensejando uma aprendizagem significativa. ${ }^{6}$

$\mathrm{E}$, principalmente, esse modelo exige um planejamento pedagógico completo e assertivo do docente da disciplina a lecionar.

\subsubsection{Planejamento pedagógico}

O planejamento do docente e da disciplina no ensino superior começa com o conhecimento do plano ou projeto pedagógico do curso oferecido pela IES. A partir dele, o docente conhece e se apropria do objetivo do curso, da concepção e da organização curricular, do perfil do aluno egresso, das metodologias de ensino e aprendizagem e da avaliação proposta. Assim, seu trabalho não se limita a lecionar determinada disciplina, mas é responsável pela formação de um profissional.

Nesse momento, o docente analisa as informações usando os saberes pedagógicos para planejar e organizar o plano de ensino de sua disciplina, além de

\footnotetext{
${ }^{6}$ O conceito de aprendizagem significativa, introduzido por Carl Rogers e David Ausubel entre as décadas de 1960 e 1970, implica o envolvimento do aluno como pessoa integral.
} 
pesquisar junto ao coordenador o histórico do curso, a disciplina e os respectivos alunos, com o objetivo de personalizar e aprimorar o plano de ensino e também construir nas aulas um olhar interdisciplinar do curso.

Esse planejamento é baseado nos objetivos de aprendizagem da disciplina, que devem ser alcançados por meio de estratégias educacionais que articulem o conteúdo disciplinar com as metodologias mais adequadas aos alunos.

Para Aquino (2007), que fala em objetivos educacionais, a definição informará sobre a profundidade e o tipo de processamento de aprendizagem que o docente deve alcançar na aula. Para a descrição desses objetivos, cita a Taxonomia de Bloom (Bloom et al., 1956), que os define em diferentes níveis de aprendizagem.

A taxonomia como instrumento é proposta por Bloom et al. (1956) para ajudar na identificação e na declaração dos objetivos ligados ao desenvolvimento cognitivo. Uma definição clara e estruturada dos objetivos instrucionais, considerando a aquisição de competências adequadas ao perfil profissional a ser formado, direcionará o processo de ensino para a escolha adequada de estratégias, metodologias, delimitação do conteúdo específico, instrumentos de avaliação e, consequentemente, para uma aprendizagem efetiva.

Algumas IES apoiam as estratégias educacionais dos cursos na taxonomia de Bloom et al. (1956), o que concorre para uma maior credibilidade e para a eficácia da aprendizagem dos alunos. Para aplicá-la, os docentes dos cursos lato sensu deveriam começar analisando o perfil dos alunos, que são graduados em diferentes cursos, o que implica trabalhar com diferentes linguagens, discursos, representações e expectativas.

Masetto (2010) complementa o entendimento sobre a elaboração das estratégias de aprendizagem:

Podemos dizer que as estratégias para a aprendizagem constituemse numa arte de decidir sobre um conjunto de disposições que favoreçam o alcance dos objetivos educacionais pelo aprendiz, desde a organização do espaço de sala de aula com suas carteiras até a preparação do material a ser usado, por exemplo, recursos audiovisuais, visitas técnicas, internet etc., ou uso de dinâmicas de grupo, ou outras atividades individuais (Masetto, 2010, p. 86). 
Portanto, espera-se que esse docente conheça diversas metodologias, recursos e técnicas de aprendizagem para fazer as melhores escolhas no planejamento da disciplina, adaptá-las a eventuais imprevistos durante as aulas e criar novas metodologias, se for necessário.

Os recursos de apoio à aprendizagem estão cada vez mais integrados à tecnologia, o que é desafiador para o docente. Com o impacto da revolução tecnológica, a produção de conhecimento e a formação de profissionais não são mais exclusivos das IES.

Os espaços ou ambientes virtuais de aprendizagem permitem que professores e alunos acessem rapidamente informações atualizadas e publicações científicas, desenvolvendo a aprendizagem autodirigida e a interaprendizagem. A internet, chats, fóruns de discussão, videoconferências e outros recursos têm tido prioridade na escolha das metodologias, seja como apoio aos encontros presenciais ou em cursos totalmente à distância.

Especialmente nos cursos lato sensu, a tecnologia é um importante recurso que precisa estar integrado aos saberes pedagógicos, sem jamais substituir o papel do docente, mas atuando como facilitadora do processo de ensino e aprendizagem.

O papel do professor como apenas repassador de informações atualizadas está no seu limite, uma vez que diariamente estamos sujeitos a ser surpreendidos com informações novas de que dispõem nossos alunos, as quais nem sempre temos oportunidade de ver nos inúmeros sites existentes na internet (Masetto, 2003, p. 14).

Apesar de os cursos de pós-graduação lato sensu terem duração mínima de 360 horas, cada disciplina dispõe de uma média de 32 horas, ou seja, apenas oito aulas. Por isso, o docente deve ser hábil na gestão do tempo nas aulas para de fato cumprir o planejamento, garantindo a melhor aprendizagem dos alunos.

Logo na primeira aula, prevê-se que essa programação seja comunicada aos alunos, para confirmar e alinhar suas expectativas em relação à disciplina. Em alguns casos, o docente precisa mediar essas expectativas, reiterando o que será ou não tratado na disciplina e oferecendo alternativas como, por exemplo, a indicação de textos complementares. 
O docente dos cursos lato sensu participa da construção e/ou da atualização do currículo da disciplina, que envolve não só a valorização do conhecimento e a atualização com a pesquisa, mas também aspectos éticos do exercício da profissão, valores sociais, culturais, políticos e econômicos e a participação na sociedade. Devido ao caráter formativo profissional, inclui o desenvolvimento de competências como, por exemplo, trabalhar em equipe, comunicar-se assertivamente e lidar com situações adversas.

No decorrer da disciplina, o docente pode precisar rever o planejamento de acordo com o desempenho e a necessidade de aprendizagem dos alunos. Para isso, dispõe de flexibilidade e capacidade de improvisação na mediação dessa aprendizagem, o que só é possível quando ele domina o conteúdo e é capaz de conduzir diferentes metodologias.

As metodologias educacionais podem ser combinadas de várias formas para atender aos objetivos da disciplina, ao perfil dos alunos e ao estilo do docente. Podemos agrupá-las a partir de três prioridades: a atuação do docente, a atuação do aluno e a interação professor-aluno.

Com foco na atuação do docente, encontramos as metodologias mais centradas no professor, sendo a mais comum a expositiva, em que o professor constrói o discurso articulando conceitos e referências bibliográficas relativas a determinada disciplina. Mesmo sendo uma metodologia tradicional, pode ser a mais eficaz para transmitir um conteúdo técnico ou explicar uma nova teoria.

Nesse caso, o docente deve apoiar-se em alguns recursos para que os momentos expositivos sejam mais dinâmicos e sustentem a atenção dos alunos. São exemplos a construção de mapas conceituais, o uso de flip chart ou quadro branco, a projeção de slides ou vídeos e, inclusive, quadros smart board.

Nas metodologias com foco na atuação do aluno, espera-se que ele construa sua aprendizagem com uma menor mediação do professor. As mais aplicadas são a leitura orientada seguida de exercícios, a pesquisa bibliográfica ou de campo e as aulas de ensino a distância (EAD), que também acontecem em cursos híbridos. 
Finalmente, com foco na interação professor-aluno, encontramos seminários em grupo, discussão e resolução de estudos de caso, visitas ou pesquisas de campo mediadas pelo docente, técnica de aprendizagem baseada em problemas (ou problem based learning - PBL), ${ }^{7}$ atividades colaborativas em grupo, simulação de situações desafiadoras da realidade dos alunos e projetos interdisciplinares.

Além de manter o dinamismo da aula, a gestão dessas metodologias educacionais permite alcançar a diversidade dos alunos e ainda contribui para a avaliação progressiva da disciplina.

Para que a avaliação seja contínua e eficaz, deve ser planejada estrategicamente em relação a seus objetivos educacionais e ser articulada a algumas metodologias, permitindo acompanhar a aprendizagem dos alunos e corrigir o planejamento, quando necessário. Para Masetto (2014, p. 14):

Precisamos de um professor com um papel de orientador das atividades que permitirão ao aluno aprender, que seja um elemento motivador e incentivador do desenvolvimento de seus alunos, que esteja atento para mostrar os progressos deles, bem como para corrigi-los quando necessário, mas durante o curso, com tempo para que seus aprendizes aprendam nos próximos encontros ou aulas que tiverem. Um professor que, com seus alunos, forme um grupo de trabalho com objetivos comuns, que incentive a aprendizagem de uns com os outros, estimule o trabalho em equipe, a busca de solução para problemas em parceria, que seja um motivador para o aluno realizar suas pesquisas e seus relatórios, que crie condições contínuas de feedback entre aluno e professor.

Cabe ao docente verificar, no desenvolvimento da disciplina que ministra, o resultado obtido nas avaliações aplicadas progressivamente nas aulas para realizar sucessivos ajustes durante o período letivo e, ao fim, para entender que conceitos e metodologias funcionaram para o alcance dos objetivos educacionais e quais precisarão ser revisados para as turmas seguintes.

Também os alunos devem fazer uma avaliação final da disciplina e do docente que a conduziu. Algumas IES de São Paulo adotam essa avaliação final como padrão em todos os cursos, mas fica a critério do docente aplicá-la para obter um feedback

\footnotetext{
${ }^{7}$ Metodologia de ensino baseada na discussão de problemas relativos ao tema de estudo e que enfatiza o aprendizado autodirigido, centrado no estudante.
} 
sobre o alcance dos objetivos educacionais da disciplina e sobre seu próprio desempenho.

Independentemente de qualquer avaliação proposta pelo docente ou pela IES, o aluno do lato sensu avalia espontaneamente o docente e a disciplina. Essa é uma característica comum desse aluno, que geralmente é quem financia o próprio estudo e quer vislumbrar possibilidades de retorno em curto prazo, seja de titulação para obter um emprego ou uma promoção, seja para aplicar concretamente a aprendizagem em seu trabalho.

\subsubsection{Prática pedagógica em aula}

A mudança do papel docente de transmissor de informações para mediador de aprendizagem ainda está na fase inicial. A sensibilização e conscientização do docente precisa atingir a todos, para que o objetivo do ensino seja de fato a aprendizagem dos alunos. Como afirma Masetto (2003, p. 23):

Essa atitude tem a ver com a compreensão mais abrangente do processo de aprendizagem e com a sua valorização no ensino superior, com a ênfase dada ao aprendiz como sujeito do processo. [...] A docência existe para que o aluno aprenda.

Portanto, o cenário da aprendizagem com o ensino centrado no docente passa a ser focado no aluno, já que ambos se tornam coparticipantes do mesmo processo. Esse docente precisa orientar as atividades com vistas à aprendizagem dos alunos, empenhando atenção constante no progresso alcançado.

Uma dimensão importante dos saberes pedagógicos do docente do ensino superior é a relação interpessoal que ele constrói com os alunos, que estimula entre eles e, ao mesmo tempo, desenvolve com colegas docentes, coordenadores e a própria IES.

As relações se constroem por meio da escuta ativa e compreensiva, que enseja vínculos com abertura para a reflexão e para o diálogo. O docente estimula a liberdade que permite questionamentos para a investigação dos alunos com autonomia e a 
sensibilidade numa relação de confiança, conquistando, assim, um papel de facilitador da aprendizagem.

Uma atitude de parceria e corresponsabilidade é extremamente importante para a formação dos alunos, sobretudo no lato sensu, que visa a prática profissional. De acordo com Masetto (2003), essa relação entre professores e alunos pode ser vista como um trabalho em equipe voltado para o alcance dos objetivos educacionais propostos.

Para Rogers (1985), a relação que se estabelece no contexto pedagógico é composta pelas atitudes do professor para com o aluno, as quais não só determinam o nível de qualidade da aprendizagem como contribuem decisivamente para o desenvolvimento pessoal do aluno. $\mathrm{O}$ autor defende a aceitação positiva incondicional da pessoa tal como ela é, sem juízos de valor ou críticas, e a capacidade empática de imergir no mundo subjetivo do outro e de participar de sua experiência, fatores que têm impacto direto na qualidade das relações interpessoais em aula.

De acordo com Tardif (2002), o ensino é uma atividade humana baseada em interações entre pessoas. Ao entrar em sala de aula, o professor está num ambiente de trabalho constituído de interações humanas que não representam um aspecto secundário ou periférico, mas constituem o núcleo que determina a própria natureza da pedagogia.

Para que o processo de ensino e aprendizagem aconteça, o docente precisa mediar a aprendizagem apoiado na relação de confiança estabelecida com os alunos. Essa mediação acontece com a parceria entre alunos e docente para atender às expectativas e necessidades do grupo, com a troca de experiências e a abertura para reflexões.

A aula acontece num tempo e num espaço, e esse ambiente também influencia a mediação da aprendizagem. O espaço físico de aprendizagem, combinado com o virtual, é uma opção que amplia a experiência do aluno. Ambientes alternativos na IES ou externos a ela também podem motivá-lo a aprender.

Nos cursos lato sensu, o papel do professor é o de facilitador não só do saber construído, mas também das condições que concorrem para a eficácia da 
aprendizagem dos alunos. Para tanto, ele precisa estar preparado e conhecer os saberes pedagógicos, adquiridos sobretudo por meio de uma formação adequada.

\subsubsection{Formação docente}

Constatada a importância dos saberes pedagógicos para a atuação docente no ensino superior, colocam-se as perguntas: como é a formação desse profissional? E como deveria ser?

A partir das orientações do MEC quanto à preparação do docente do ensino superior, salientamos:

Se fará em nível de pós-graduação, prioritariamente em programa de mestrado e doutorado, conforme o artigo 66 da Lei de Diretrizes e Bases da Educação Nacional. Portanto, cabe à instituição, desde que atendido o ato normativo acima citado, definir a qualificação de seus docentes (Brasil, [s.d.]).

A primeira questão é sobre a definição da preparação em nível de mestrado ou doutorado, que prioriza à formação de pesquisadores bem mais do que à de professores para o ensino superior, o que compromete a construção dos saberes pedagógicos. Chamlian (2006, p. 75) explica que essa preocupação é recente:

No Brasil, os cursos de pós-graduação têm sido considerados o locus "natural" da formação do professor universitário. A ênfase desses cursos, porém, sempre esteve centrada na formação do pesquisador. Nos anos oitenta, uma das poucas medidas legais que indicavam alguma preocupação com a docência traduziram-se na recomendação para introduzir uma disciplina intitulada "Metodologia do Ensino Superior" nos cursos de pós-graduação da área médica.

Outra preocupação é a afirmação de que cabe à instituição definir a qualificação dos docentes, sem apresentar uma orientação clara ou um sistema definido de padronização mínima de formação ou qualificação dos docentes.

Finalmente, devemos considerar que a maior parte dos docentes do lato sensu são contratados para atuar apenas num certo número de horas semanais (por cartaconvite), o que dificulta qualquer ação pedagógica formativa adicional a sua atuação em sala de aula. 
Nos cursos lato sensu, encontramos docentes com título de mestre, doutor ou especialista. Em nenhum dos três casos são obrigatórias disciplinas voltadas para a formação para a docência, como a metodologia do ensino superior ou a prática de ensino, que ocorre principalmente em estágios supervisionados.

Logo, seja qual for a titulação do professor, dificilmente ele terá os saberes pedagógicos devidamente desenvolvidos e, por essa razão, pode não estar totalmente qualificado para exercer a função docente. Embora tenha os saberes disciplinares e experienciais necessários, na maioria das vezes faltam-lhe conhecimentos pedagógicos.

Mesmo que o MEC (Brasil, [s.d.]) afirme que o regime de trabalho e a qualificação do docente influenciam diretamente a avaliação do Sistema Nacional de Avaliação da Educação Superior (Sinaes), não encontramos uma regulamentação com critérios e acompanhamento consistentes que garantam a formação pedagógica desses docentes do lato sensu. Na maior parte das vezes, essa preparação fica a cargo do próprio docente ou de sua instituição de ensino.

Como já foi mencionado, nos cursos lato sensu, por sua natureza e pelo perfil dos docentes, há um número considerável de especialistas e professores contratados como horistas ou temporariamente (por carta-convite). Assim, quando a IES oferece ações de formação contínua, elas ficam sujeitas à disponibilidade de horários e ao investimento do tempo pessoal dos docentes, o que não assegura o desenvolvimento dos saberes pedagógicos ou a qualificação adequada do corpo docente. Nesses termos, a formação desse docente para o ensino superior depende de iniciativas individuais e institucionais circunstanciais, desatrelada de um projeto mais amplo e da própria categoria docente.

Entretanto, para entender e melhor discutir a formação pedagógica dos docentes, é importante verificar a contribuição de alguns autores sobre a formação inicial de novos professores, assim como a formação contínua dos que já lecionam.

De acordo com Soares (2009, p. 103), o desenvolvimento dos saberes pedagógicos é "um processo complexo que acredito exigir uma formação 'inicial', mas atravessa toda a trajetória profissional dos professores". Assim, não é suficiente acentuar apenas a importância da prévia formação pedagógica do docente. Como em 
qualquer outra profissão, é preciso que ele seja protagonista da própria formação continuada durante toda a sua carreira profissional.

Esteve (1995) aponta dois aspectos importantes na formação inicial dos docentes: a substituição de abordagens normativas (professor ideal) por abordagens descritivas (condicionantes da relação professor-aluno) e a adequação dos conteúdos à realidade dos alunos. Para o autor, a parte prática da formação inicial precisa estimular o futuro docente a se identificar como professor e com os estilos de ensino que é capaz de adotar, considerando seus efeitos nos alunos. Concomitantemente, deve desenvolver a capacidade de identificar problemas que surjam em sala de aula.

Ao buscar uma visão ampla da formação docente, encontramos uma pesquisa de Chamlian (2006) sobre a formação do professor universitário em 1998, que resultou na postulação dos seguintes princípios:

O que seria importante promover:

1) Apropriação de seu patrimônio vivencial;

2) Transformação individual da tríplice dimensão: saber, saber-fazer, saber-ser. Para tanto: implicação, participação, interação, cooperação.

3) Autonomização e independência intelectual (formação-ação, formação-investigação, formação-inovação).

4) Busca/definição de um projeto (de curto, médio e longo prazo) (Chamlian, 2006, p. 87).

Para Zabalza (2004), a formação de professores universitários deve ser vista da perspectiva da profissionalização de uma atividade complexa, que carece de uma formação específica e contínua para atender às constantes atualizações do mundo de trabalho, em contínua transformação. Essa formação se constrói nos dilemas e questionamentos sobre seu sentido e sua relevância, o conteúdo, o público e os atores, assim como os modelos e as metodologias.

Para que a docência seja de fato considerada uma profissão, não pode estar vinculada apenas ao aprendizado obtido da prática em aula. Almeida (2012, p. 73) entende que essa formação precisa estar baseada em quatro grandes eixos:

(a) Concepções a respeito de si e do próprio papel social que dão sustentação à identidade profissional; (b) componentes que integram os processos formativos, como teorias e práticas, conteúdos da área específica de atuação, conhecimentos didático-pedagógicos; (c) 
contextos de formação e de trabalho; (d) processos de construção do conhecimento e de desenvolvimento profissional.

A formação contínua precisa basear-se na profissionalidade docente, e não se restringir ao ensino de conteúdos ou destrezas. Sacristán (1995) defende que a mudança pedagógica e o aperfeiçoamento dos professores devem ser entendidos no quadro do desenvolvimento pessoal e profissional como parte da cultura institucional, questão desafiadora para o docente do lato sensu:

A prática profissional depende de decisões individuais, mas rege-se por normas colectivas adoptadas por outros professores e por regulações organizacionais. A cultura da instituição é muito importante, mas é preciso não se esquecer das determinações burocráticas da organização escolar (Sacristán, 1995, p. 71).

Nesse sentido, Nóvoa (1992) questiona os modelos atuais de formação de professores. Afirma que os modelos acadêmicos baseados em conhecimentos científicos separam a teoria da prática e propõe um modelo que as unifique e concorra para a construção de identidades docentes mais efetivas e relacionais. Para o autor, a formação do profissional docente deve se desenvolver em três dimensões: pessoal (referente à vida do professor), profissional (referente à profissão docente) e organizacional (referente à instituição educacional):

A formação deve estimular uma perspectiva crítico-reflexiva, que forneça aos professores os meios de um pensamento autônomo e que facilite as dinâmicas de autoformação participada. Estar em formação implica um investimento pessoal, um trabalho livre e criativo sobre os percursos e os projetos próprios, com vista à construção de uma identidade, que é também uma identidade profissional (Nóvoa, 1992, p. 25).

Essa visão nos leva a considerar que o docente é, antes de tudo, um ser humano integral, com sua história de vida, formação, identidade, desenvolvimento e saberes. Essa perspectiva crítico-reflexiva deve atravessar toda esta pesquisa, sobretudo na análise dos saberes pedagógicos do docente do lato sensu.

Assim, mesmo tendo um título de mestre, doutor ou especialista, o docente do lato sensu, ao deparar, na prática profissional, a necessidade de formação e preparação pedagógicas, procura complementar seus saberes pedagógicos em cursos de pós-graduação de docência para o ensino superior ou em outros cursos livres correlatos. 
Essa busca se confirma pelo aumento da oferta desses cursos por diversas instituições de ensino nos últimos anos. O Centro Universitário Senac, a Universidade Metodista de São Paulo, a Universidade Paulista (UNIP), a Faculdades Metropolitanas Unidas (FMU), a Universidade Cidade de São Paulo (UNICID), a FGV, a Universidade Presbiteriana Mackenzie, a Universidade Anhembi Morumbi e a Pontifícia Universidade Católica de São Paulo (PUC) são apenas algumas das IES que hoje oferecem cursos de docência para o ensino superior na cidade de São Paulo. ${ }^{8}$

Diante das conceituações e propostas apresentadas sobre o universo do docente do lato sensu, percebemos que existe uma carência na formação para a docência e para o desenvolvimento dos saberes pedagógicos desses professores, o que é investigado por esta pesquisa.

Devido às restrições de dedicação à docência, as formações autodirecionadas são as que mais acontecem em conjunto com outras iniciativas pontuais das IES em que atuam. Esse docente não pode ser o único agente consciente dessa importância formativa, pois essa é uma responsabilidade compartilhada com as IES e o governo. Nesse sentido:

O certo é que existe, no discurso pedagógico dominante, uma hiperresponsabilização dos professores em relação à prática pedagógica e à qualidade do ensino, situação que reflete a realidade de um sistema escolar centrado na figura do professor como condutor visível dos processos institucionalizados de educação. A prática tem que ver com os professores, mas não depende unicamente deles. (Sacristán, 1995, p. 64).

Portanto, consideramos que a formação do docente do lato sensu deveria ser inicial e contínua, baseada em conceitos ligados às práticas docentes, que the permitam refletir sobre o significado da atuação pedagógica e educacional, bem como sobre a construção de sua identidade profissional.

\subsubsection{Pesquisas recentes sobre o tema}

\footnotetext{
${ }^{8}$ Cursos encontrados nos respectivos websites das instituições, acessados em 10 de dezembro de 2016.
} 
Apesar de não havermos encontrado um vasto conjunto de informações sobre a realidade dos saberes pedagógicos de docentes de cursos lato sensu, foi possível conhecer alguns dados importantes a partir de pesquisas publicadas.

Soares (2009) revela que são poucas as pesquisas em programas de pósgraduação sobre a formação do professor do ensino superior e que, assim como os indicadores de qualidade, os processos de avaliação externa correntes nas universidades brasileiras parecem valorizar mais o papel do professor como pesquisador.

A visão tradicional do professor responsável pela transmissão do conhecimento sistematizado na forma magistral e erudita é ainda muito presente. Ao mesmo tempo, as IES não estimulam financeiramente o investimento na formação pedagógica de docentes, como fazem para a formação de pesquisadores.

Algumas iniciativas importantes concorrem para valorizar a docência - por exemplo, a obrigatoriedade do estágio supervisionado na docência para bolsistas da Comissão de Aperfeiçoamento de Pessoal do Nível Superior (CAPES) ${ }^{9}$ em mestrado e doutorado -, mas elas não são suficientes para modificar a carência do cenário atual.

Ainda para Soares (2009), a ampliação da consistência teórica e a afirmação social e prática do estudo e da pesquisa da pedagogia universitária pode sensibilizar os órgãos governamentais que deveriam elaborar políticas para regulamentar, oferecer formação específica e rever o recrutamento e o plano de carreira contemplando a importância dos saberes da docência. Assim, favoreceriam a melhor qualidade e a valorização da pedagogia universitária.

Soares (2009) também afirma que, desde 1980, vem aumentando o interesse nesse tema e em pesquisas nessa linha, o que pode ser verificado na criação de redes de pesquisa e na realização de simpósios e fóruns internacionais e nacionais.

\footnotetext{
${ }^{9}$ Órgão do Ministério da Educação responsável pelo reconhecimento e pela avaliação de cursos de pós-graduação stricto sensu (mestrado profissional, mestrado acadêmico e doutorado) em âmbito nacional.
} 
De acordo com Pimenta e Anastasiou (2011), uma das formas de contato dos professores com as questões pedagógicas seria a introdução da disciplina de Metodologia do Ensino Superior nos cursos lato sensu, mas, mesmo assim, sua carga horária não ultrapassaria 60 horas, o que é insuficiente para uma formação de qualidade.

Outra forma de capacitação pedagógica são os cursos de especialização em docência para o ensino superior, como já mencionado, mas geralmente são realizados devido ao interesse ou à necessidade do próprio docente, depois de se haver especializado em sua área de ensino ou mesmo de ter concluído uma pós-graduação stricto sensu.

Chamlian (2003) corrobora essa visão com sua pesquisa com professores da USP considerados inovadores, conduzida de novembro de 1994 a junho de 1995, que visava subsidiar a formação do professor universitário. A autora entrevistou os docentes inovadores considerando como questão teórica central compreender a relação ensino e pesquisa e os efeitos desse processo na atuação docente.

O grupo pesquisado era de professores participantes do Seminário sobre Experiências Inovadoras do Ensino, realizado na FEUSP em 1991. A amostra compunha-se de 18 professores, com 53 experiências relatadas. Eram 10 mulheres e oito homens, com uma média de 45 a 50 anos, de formações diversas, sendo a maior parte nas áreas de ciências humanas ou saúde, com nível de doutorado e com 15 a 25 anos de experiência.

Os resultados da pesquisa apontaram a necessidade de diversas ações de caráter inovador, tais como reformulação curricular e dos estágios, criação de disciplina optativa para a formação de docente, criação de laboratórios, desenvolvimento de cursos com enfoque profissional, reformulação das atividades de laboratório, criação de oficinas, adoção de novos recursos didáticos e tecnológicos e substituição da prova final por exercícios.

Os professores pesquisados também apontaram o exercício da criatividade, o aprendizado e a mudança do rumo das práticas docentes e das investigações. A autora conclui que a questão principal a reforçar é a sensibilização para a dificuldade 
pedagógica e a valorização do ensino ligado à pesquisa por parte não só dos docentes, mas também das instituições universitárias.

A proposição de questões sobre a sua própria preparação para a atividade docente e sobre a maneira pela qual encaravam a formação de novos professores, baseados em sua própria experiência, pretendia estabelecer uma interlocução que permitisse pensar de forma mais plural sobre o tema. Não ficou evidente a necessidade de uma formação pedagógica estrita, mas a de valorização da tarefa de ensino na universidade conjugada à atividade de pesquisa (Chamlian, 2009, p. 217).

$\mathrm{Na}$ mesma linha, Vasconcelos (2014) relata estudos e pesquisas com professores universitários realizados a partir da experiência como docente, desde 1990, da disciplina Metodologia do Ensino Superior em cursos de pós-graduação stricto sensu.

A autora explica que esses cursos foram desenvolvidos com um caráter particular, porque reúnem um elenco obrigatório de disciplinas pedagógicas voltadas à adequada formação para o exercício do magistério de todos os futuros mestres e doutores, mesmo não havendo exigência legal nesse sentido.

Ao longo da sua prática, considerada bastante instigante e inovadora, Vasconcelos (2014) desenvolveu sua tese de doutorado, orientada para compreender o perfil do professor universitário, especialmente o que não tem formação pedagógica.

Baseada em observações, notas, aplicação de questionários e entrevistas não estruturadas, a autora buscou:

[...] a elucidação de pontos ainda pouco claros, como as razões que levavam profissionais de outras áreas ao exercício do magistério, o real comprometimento no desempenho do papel de professor por parte dessas pessoas e a condição de necessidade de um trabalho voltado para a formação pedagógica desses profissionais. Buscaram, ainda, justificar a necessidade de uma formação pedagógica para a real "profissionalização" docente (Vasconcelos, 2014, p. 80).

Os resultados foram esclarecedores e fundamentais para conhecer melhor 0 perfil do professor universitário. A autora relata que, dos 280 questionários distribuídos em quatro IES da Grande São Paulo, apenas 48 foram devolvidos, ou seja, $17,1 \%$ dos professores atenderam à solicitação e responderam à pesquisa. Complementa que, por si só, esse pequeno número de respostas obtidas já demonstra pouco 
envolvimento com a vida acadêmica por parte desses professores. Essa foi uma dificuldade também encontrada nesta pesquisa.

Vasconcelos (2014) compartilha alguns depoimentos dos professores entrevistados, que revelam visões e percepções sobre a valorização dos saberes experienciais por parte dos alunos:

O que vale é a realidade do mercado de trabalho com o qual convivo. Eu sei o que é mais importante e meus alunos confiam em minha experiência (Administrador de empresas).

O aluno não aguenta mais tanta teoria. O meu recado é real, concreto. Há 25 anos exerço essa função e posso dizer que sei tudo o que se pede aí fora. Na universidade, há uma preocupação excessiva com a teoria, quando o aluno quer é aprender o seu ofício (Administrador de recursos humanos) (Vasconcelos, 2014, p. 83).

A pesquisa também mostra que a grande maioria dos respondentes $(68,7 \%)$ começou no magistério a convite de um conhecido, quase por acaso:

$\mathrm{E}$, de repente, eu me vi diante das feras sem ter a menor ideia do que fazer para ministrar uma aula que fosse ao menos decente!

No início, tudo era muito complicado: o relacionamento, a manutenção da disciplina, a avaliação. [...] Com o tempo, entre um erro e um acerto, fui aprendendo a dar aulas.

[...] Até que, um dia, parei e resolvi começar do zero. Ouvi colegas, li muita bibliografia pedagógica e mudei tudo na minha aula. Hoje, acho que sou uma boa professora, mas no início, coitados dos meus alunos! (Vasconcelos, 2014, p. 85).

A autora ressalta que $72 \%$ dos professores não tiveram nenhuma formação pedagógica e que, nas observações e entrevistas, constatou uma forte resistência a frequentar esse tipo de curso. Segundo sua percepção, mesmo quando há preocupação com a formação pedagógica, sobretudo em discussões sobre os cursos de pós-graduação stricto e lato sensu, o enfoque principal é a pesquisa ou a competência técnica relativa ao conteúdo disciplinar específico.

Essa pesquisa reitera que a formação pedagógica de mestres e doutores (dos diversos cursos de pós-graduação do país) ainda não é prioridade nem para os próprios docentes. 
Buscando dados para esta, encontramos também a pesquisa de Gonçalves (2013), sobre saberes e práticas docentes de cursos lato sensu na mesma IES selecionada aqui. Em suas próprias palavras:

A análise dos dados confirmou a hipótese de que os professores que atuam no lato sensu resgatam seus saberes e práticas de experiências vivenciadas quando eram alunos, tomando como modelo referências que tiveram ao longo de sua trajetória formativa e profissional. Foi constatado que, na maioria das vezes, o professor só procura a formação pedagógica após já estar inserido no contexto da atuação no lato sensu, dependendo quase exclusivamente, de uma busca por iniciativa própria, uma vez que a legislação não predetermina qual o perfil deste professor para atuação no lato sensu. Constituem-se docentes de maneira gradual e a formação pedagógica é mais uma possibilidade para a atuação, uma vez que em primeiro lugar vem a experiência da prática profissional de sua área de formação de origem (Gonçalves, 2013, p. 5).

A autora confirma que o apoio dos saberes pedagógicos à prática docente ainda é precário, levando a que os docentes do lato sensu atuem de acordo com suas convicções pessoais ou por meio de estratégias aprendidas na própria experiência.

É nesse sentido que Nóvoa (1995) afirma que a possibilidade de a teoria fecundar a prática é limitada e que é preciso incentivar a aquisição progressiva de uma consciência sobre a prática sem desvalorizar a teoria. Entretanto, apesar dos resultados relatados e das afirmações dos autores, pesquisas sobre os saberes pedagógicos têm crescido nos últimos anos, desenvolvendo estudos e projetos conduzidos por grupos, associações e redes de pesquisadores.

Na USP, duas equipes dedicam-se a esses estudos, o Grupo de Estudos e Pesquisas sobre Formação de Educador (GEPEFE), coordenado pelas professoras doutoras Maria Isabel de Almeida e Selma Garrido Pimenta, e o projeto de pesquisa Profissão Docente - Desafios Contemporâneos, conduzido pela professora doutora Helena Coharik Chamlian.

Essa questão é também pesquisada por associações e redes como a Rede Sul-Brasileira de Investigadores de Educação Superior (RIES) e a Asociación Internacional de Pedagogía Universitária (AIPU).

Verificamos, ao longo deste capítulo, que, para analisar os saberes pedagógicos docentes, é necessário sempre considerar seu contexto e sua identidade 
em construção, nunca apenas o saber isolado. O compromisso e o desenvolvimento dos saberes pedagógicos deveriam preceder a prática profissional docente, mas, muitas vezes, o próprio professor só reconhece a importância dessa formação nos primeiros anos em sala de aula e a partir de reflexões sobre sua prática.

Assim, para entender, confirmar e ampliar o conhecimento sobre esses saberes pedagógicos, foi efetuada a pesquisa de campo com os próprios docentes de cursos de pós-graduação lato sensu. 


\section{CAPÍTULO 3}

\section{SABERES PEDAGÓGICOS DE DOCENTES DO LATO SENSU DE UMA IES EM SÃO PAULO}

\subsection{A pesquisa de campo}

A revisão de literatura desenvolvida nos Capítulos 1 e 2 permitiu compreender melhor o histórico e o cenário atual do ensino superior e dos cursos de pós-graduação lato sensu, assim como os saberes pedagógicos dos docentes que participaram da pesquisa de campo.

Apesar de haver localizado algumas pesquisas que articulam alguns desses aspectos, consideramos importante verificar entre os próprios docentes do lato sensu de uma IES da cidade de São Paulo como eles percebem seus saberes pedagógicos e seu papel num processo de ensino e aprendizagem. Acreditamos que, assim, podem-se comparar os estudos encontrados - e apresentados nesta dissertação com a realidade atual desses sujeitos.

Em função do tema e da área estudados, optamos por aplicar a pesquisa qualitativa, cujas características atendem à natureza desta pesquisa. Alves (1991) aponta dois aspectos essenciais: sua visão holística (só se pode compreender o significado de um comportamento ou evento verificando as inter-relações que emergem de dado contexto) e sua abordagem indutiva (o pesquisador parte de observações mais livres, permitindo que as categorias de interesse surjam progressivamente durante o processo de coleta e análise de dados). Assim, a investigação tem caráter naturalístico, reduzindo ao mínimo a intervenção do pesquisador no contexto observado:

[...] Não se pode, no processo de investigação, deixar de valorizar a imersão do pesquisador no contexto, em interação com os participantes, procurando apreender o significado por eles atribuído aos fenômenos estudados. É também compreensível que o foco do estudo vá sendo progressivamente ajustado durante a investigação e que os dados dela resultantes sejam predominantemente descritivos e expressos através de palavras (Alves, 1991, p. 55).

A visão holística do estudo surgiu já na revisão de literatura apresentada nos Capítulos 1 e 2, bem como na pesquisa sobre a IES em São Paulo, seus docentes e 
alunos da pós-graduação lato sensu e, principalmente, pelo fato de eu também ser uma docente convidada nessa IES há sete anos, ministrando disciplinas em diferentes cursos.

A pesquisa qualitativa em educação demanda imenso cuidado, desde o planejamento até as conclusões. André (2001) explica que esse tipo de pesquisa passou a se tornar mais complexa e com temas e referenciais diversificados nos anos 1980-90, ampliando o espaço dos estudos ditos qualitativos, que:

Englobam um conjunto heterogêneo de perspectivas, de métodos, de técnicas e de análises, compreendendo desde estudos do tipo etnográfico, pesquisa participante, estudos de caso, pesquisa-ação até análises de discurso e de narrativas, estudos de memória, histórias de vida e história oral (André, 2001, p. 54).

Mudaram também as preocupações do pesquisador em educação, que passou a questionar mais as situações reais do cotidiano escolar e da sala de aula. Outra mudança foi o desenvolvimento de pesquisas com a colaboração dos participantes. Tudo isso levou ao questionamento dos instrumentos teórico-metodológicos e dos parâmetros do julgamento da qualidade do trabalho científico.

A autora acredita que o ponto de origem de uma investigação científica é a formulação da pergunta adequada e complementa:

As questões a serem perseguidas na área de educação são ainda tantas e de tamanha variedade que não podemos nos perder em polêmicas que só nos deixarão cada vez mais distantes da realidade. São tantas as perguntas relevantes que ainda não foram formuladas, tantas as problemáticas que ainda precisamos conhecer, que sobram espaços para todo tipo de investigação, desde que se cuide da sistematização e controle dos dados. Que o trabalho de pesquisa seja devidamente planejado, que os dados sejam coletados mediante procedimentos rigorosos, que a análise seja densa e fundamentada e que o relatório descreva claramente o processo seguido e os resultados alcançados (André, 2001, p. 57).

Entre esses critérios, destaca-se a relevância científica e social dos trabalhos, que se devem inserir num quadro teórico em que fiquem evidentes a contribuição ao conhecimento já disponível e a opção por temas engajados na prática social. 
Baseada nesses requisitos, esta pesquisa de campo foi planejada inicialmente com o objetivo de compreender como são compostos os saberes pedagógicos dos docentes de cursos de pós-graduação lato sensu na IES selecionada.

Para chegar a esse entendimento, era preciso conhecer o perfil completo desses docentes: sua formação e sua experiência profissional, o tempo de docência, as horas de dedicação semanal à docência e o tipo de contratação, para depois ouvir suas próprias reflexões e afirmações sobre o tema pesquisado.

Sendo assim, foram elaborados dois instrumentos de pesquisa: o questionário on-line e o roteiro semiestruturado de entrevista. Mais uma vez, a escolha desses instrumentos deveu-se a algumas especificações.

A pesquisa dos saberes pedagógicos dos docentes exigiu um contato individual e presencial não só para colher informações, mas também para perceber mensagens subliminares e interpretar suas expressões não verbais.

Pela própria natureza dos cursos e pelo pouco tempo extraclasse, a maior parte dos docentes do lato sensu não costuma ter contato frequente com seus pares. Consequentemente, o melhor instrumento era mesmo a entrevista semiestruturada, que permite esse contato pessoal e a flexibilidade de sua condução para melhor entendimento das informações.

Como vimos, a disponibilidade da maioria desses docentes para participar de pesquisas e atividades extraordinárias é restrita, pois não são todos contratados em regime de dedicação exclusiva e com vínculo empregatício com a IES. Portanto, as entrevistas deveriam ser o mais produtivas possível, durando, em média, uma hora, com pequenas variações de acordo com a disponibilidade e participação dos entrevistados. Nesses termos, a aplicação de um questionário prévio forneceria dados iniciais sobre o perfil desses docentes, além de informações relevantes para a preparação das entrevistas. E a solução de aplicá-lo virtualmente permitiria que o docente o preenchesse à distância, conforme sua disponibilidade.

Essa composição de instrumentos complementares aprimorou a qualidade e a quantidade das informações coletadas sobre o tema e o perfil dos sujeitos pesquisados, que são apresentados a seguir. 


\subsection{Perfil dos docentes entrevistados}

A IES selecionada é privada, fica na cidade de São Paulo e foi escolhida por ser considerada referência nacional de qualidade em educação profissional, por seu posicionamento pedagógico com ênfase na aprendizagem, por defender o papel do docente como mediador e orientador e por ser uma instituição na qual também sou docente dos cursos lato sensu, o que facilita a compreensão do cenário e dos sujeitos da pesquisa.

Depois de a pesquisa ter sido aprovada pela IES, foram indicados quatro coordenadores dos cursos lato sensu de mesma natureza, que compartilharam os contatos de seus respectivos docentes que gostariam participar da amostra.

A receptividade desses coordenadores foi satisfatória; eles se dispuseram também a participar da pesquisa e indicaram o grupo de docentes de cada curso, sinalizando que seria mais fácil entrevistar os contratados pela CLT do que os que trabalhavam por tempo determinado (por carta-convite), pois estes não têm vínculo formal com a IES.

No momento da realização da pesquisa, no primeiro semestre de 2016, pedimos à IES informações sobre o cenário dos cursos lato sensu e o perfil de seus docentes. Fomos informados de que existiam dez cursos, conduzidos por 42 docentes, sendo $23 \%$ deles contratados pela CLT e $77 \%$ como convidados por tempo determinado (por carta-convite). Quanto à titulação, 50\% eram mestres, 31\% especialistas e $19 \%$ doutores.

Os docentes que afinal participaram desta pesquisa lecionavam nos cursos lato sensu indicados, quais sejam, os de Responsabilidade Social Empresarial e Sustentabilidade, de Controladoria e Finanças, de Marketing de Varejo e de Gestão Estratégica de Pessoas. Em janeiro de 2016, esses cursos tinham um total de 39 docentes, o que representava $93 \%$ do lato sensu na unidade, ou seja, uma parte definitivamente representativa do total.

Todavia, apenas 16 docentes $(41,03 \%$ da amostra) responderam à pesquisa on-line, um fato preocupante e que mereceu atenção, mas que não surpreendeu, em face das pesquisas já realizadas com esse público. Ao mesmo tempo, a amostra pode 
ser considerada significativa, pois a pesquisa qualitativa que exige profunda análise das informações coletadas e a reincidência dos dados refletiriam as múltiplas dimensões do objeto de estudo.

Formalizado o Termo de Consentimento da Entrevista (Anexo), desenvolvido a partir das diretrizes do Código de Ética da USP, aplicou-se o questionário on-line (Apêndice A), elaborado por uma ferramenta virtual e composto pelas seguintes perguntas:

1. Por favor, informe seus dados: idade, gênero, tempo de docência.

2. Qual é sua formação acadêmica (graduação e pós-graduação)?

3. Que disciplinas você está conduzindo como docente atualmente?

4. Quantas horas semanais você dedica apenas à docência (incluindo condução das aulas e atividades extraclasse)?

5. Como é caracterizado seu tipo de contratação com a instituição de ensino na qual estamos realizando a pesquisa?

6. Relate brevemente sua experiência profissional como docente.

7. Você também atua em outra profissão, além da docência?

8. Em caso positivo, qual seria essa outra profissão?

Os 16 respondentes foram convidados a participar da segunda fase da pesquisa: entrevistas individuais com o apoio de um roteiro semiestruturado (Apêndice B). Todavia, apesar de diversas tentativas, apenas oito docentes concordaram em ser entrevistados acerca de seus saberes pedagógicos. Do restante da amostra de 16 professores, um havia mudado de estado e, portanto, não poderia mais participar, e outros sete deixaram de responder a nossos contatos.

No Quadro a seguir, é apresentado o perfil dos 16 docentes respondentes do questionário on-line prévio, denominados como Grupo $A$. Como Grupo $B$, os oito entrevistados para efeito de análise, considerando que o grupo B também pertence ao grupo $A$.

Organizamos as informações levantadas nas categorias: gênero, idade, titulação, tipo de contratação, formação acadêmica, tempo de docência, horas de dedicação semanal à docência, cursos de atuação na IES, tipo de contratação e a atual dedicação exclusiva à docência. 
Quadro - Perfil dos docentes do lato sensu da IES

\begin{tabular}{|c|c|c|}
\hline Categoria & $\begin{array}{c}\text { Grupo } A \\
\text { perfil dos } 16 \text { docentes entrevistados }{ }^{10}\end{array}$ & $\begin{array}{c}\text { Grupo B } \\
\text { perfil dos } 8 \text { docentes entrevistados }\end{array}$ \\
\hline Gênero & $\begin{array}{l}10 \text { homens }(62,5 \%) \\
6 \text { mulheres }(37,5 \%)\end{array}$ & $\begin{array}{l}6 \text { homens }(66,66 \%) \\
2 \text { mulheres }(33,33 \%)\end{array}$ \\
\hline Idade & $\begin{array}{l}\text { média geral: } 44 \text { anos } \\
30 \text { a } 39 \text { anos: } 7 \text { docentes }(43,75 \%) \\
40 \text { a } 49 \text { anos: } 4 \text { docentes }(25 \%) \\
50 \text { a } 59 \text { anos: } 3 \text { docentes }(18,75 \%) \\
\text { mais de } 60 \text { anos: } 2 \text { docentes }(12,5 \%)\end{array}$ & $\begin{array}{l}\text { média geral: } 45 \text { anos } \\
30 \text { a } 39 \text { anos: } 3 \text { docentes }(37,5 \%) \\
40 \text { a } 49 \text { anos: } 2 \text { docentes }(25 \%) \\
50 \text { a } 59 \text { anos: } 2 \text { docentes }(25 \%) \\
\text { mais de } 60 \text { anos: } 1 \text { docente }(12,5 \%)\end{array}$ \\
\hline \multirow{2}{*}{ Titulação } & $\begin{array}{l}\text { especialistas: } 6(37,5 \%) \\
\text { mestres: } 6(37,5 \%) \\
\text { doutores: } 4(25 \%)\end{array}$ & $\begin{array}{l}\text { especialistas: } 3(37,5 \%) \\
\text { mestres: } 3(37,5 \%) \\
\text { doutores: } 2(25 \%)\end{array}$ \\
\hline & $\begin{array}{l}\text { Do total de docentes do lato sensu da } \\
\text { IES, } 31 \% \text { são especialistas, } 50 \% \text { são } \\
\text { mestres e } 19 \% \text { são doutores }\end{array}$ & $\begin{array}{l}\text { Do total de docentes do lato sensu da } \\
\text { IES, } 31 \% \text { são especialistas, } 50 \% \text { são } \\
\text { mestres e } 19 \% \text { são doutores }\end{array}$ \\
\hline \multirow[b]{2}{*}{$\begin{array}{l}\text { Tipo de } \\
\text { contrato }\end{array}$} & $\begin{array}{l}\text { CLT: } 5 \text { docentes }(31,25 \%) \\
\text { carta-convite: } 11 \text { docentes }(68,75 \%)\end{array}$ & $\begin{array}{l}\text { CLT: } 3 \text { docentes (38\%) } \\
\text { carta-convite: } 5 \text { docentes (62\%) }\end{array}$ \\
\hline & $\begin{array}{l}\text { Do total de docentes do lato sensu da } \\
\text { IES, } 23 \% \text { são contratados pela CLT e } \\
77 \% \text {, por carta-convite por tempo } \\
\text { determinado }\end{array}$ & $\begin{array}{l}\text { Do total de docentes do lato sensu da } \\
\text { IES, } 23 \% \text { são contratados pela CLT e } \\
77 \% \text {, por carta-convite por tempo } \\
\text { determinado }\end{array}$ \\
\hline $\begin{array}{l}\text { Formação } \\
\text { acadêmica }\end{array}$ & $\begin{array}{l}\text { graduação: } 9 \text { áreas } \\
\text { - } \text { administração de empresas } \\
\text { - ciências da computação } \\
\text { - ciências contábeis } \\
\text { - ciências jurídicas } \\
\text { - comunicação } \\
\text { - economia } \\
\text { - jornalismo } \\
\text { - pedagogia } \\
\text { pós-graduação lato sensu: } 8 \text { áreas } \\
\text { - administração de recursos humanos } \\
\text { - jornalismo } \\
\text { - sociologia ambiental } \\
\text { - gestão de marketing } \\
\text { - gestão de negócios } \\
\text { - finanças em empresas } \\
\text { - qualidade e produtividade } \\
\text { - mamresarial }\end{array}$ & $\begin{array}{l}\text { graduação: } 3 \text { áreas } \\
\text { - administração de empresas } \\
\text { - } \text { economia } \\
\text { - jornalismo } \\
\text { pós-graduação lato sensu: } 5 \text { áreas } \\
\text { - } \text { administração de recursos } \\
\text { - } \text { gumanos } \\
\text { - gestão de marketing } \\
\text { - } \text { finanças em empresas } \\
\text { - qualidade e produtividade } \\
\text { empresarial }\end{array}$ \\
\hline
\end{tabular}

\footnotetext{
${ }^{10}$ Os docentes do grupo A responderam apenas à pesquisa on-line, pois não tinham disponibilidade para ser entrevistados, como os do grupo B.
} 
[continuação]

\begin{tabular}{|c|c|c|}
\hline Categoria & $\begin{array}{c}\text { Grupo A } \\
\text { perfil dos } 16 \text { docentes entrevistados }\end{array}$ & $\begin{array}{c}\text { Grupo B } \\
\text { perfil dos } 8 \text { docentes entrevistados }\end{array}$ \\
\hline Formação & $\begin{array}{l}\text { pós-graduação stricto sensu: } 9 \text { áreas } \\
\text { - } \text { administração } \\
\text { - } \text { antropologia } \\
\text { - ciências da comunicação } \\
\text { - ciência ambiental } \\
\text { - } \text { comunicação social } \\
\text { - } \text { gestão e pessoas } \\
\text { - } \text { marketing } \\
\text { - } \text { serviço social }\end{array}$ & $\begin{array}{l}\text { pós-graduação stricto sensu: } 4 \text { áreas } \\
\text { - administração } \\
\text { - gestão e pessoas } \\
\text { - marketing } \\
\text { - serviço social }\end{array}$ \\
\hline $\begin{array}{l}\text { Tempo de } \\
\text { docência }\end{array}$ & $\begin{array}{l}\text { média total: } 11 \text { anos } \\
0 \text { a } 5 \text { anos: } 3(18,75 \%) \\
6 \text { a } 10 \text { anos: } 9(56,25 \%) \\
11 \text { a } 20 \text { anos: } 2(12,5 \%) \\
20 \text { a } 30 \text { anos: } 1(6,25 \%) \\
\text { mais de } 30 \text { anos: } 1(6,25 \%)\end{array}$ & $\begin{array}{l}\text { média total: } 13 \text { anos } \\
0 \text { a } 5 \text { anos: } 2(25 \%) \\
6 \text { a } 10 \text { anos: } 3(37,5 \%) \\
11 \text { a } 20 \text { anos: } 1(12,5 \%) \\
20 \text { a } 30 \text { anos: } 1(12,5 \%) \\
\text { mais de } 30 \text { anos: } 1(12,5 \%)\end{array}$ \\
\hline $\begin{array}{l}\text { Horas } \\
\text { semanais } \\
\text { dedicadas } \\
\text { à docência }\end{array}$ & $\begin{array}{l}\text { média total: } 14 \text { horas } \\
0 \text { a } 8 \text { horas: } 6(37,5 \%) \\
9 \text { a } 16 \text { horas: } 4(25 \%) \\
17 \text { a } 24 \text { horas: } 4(25 \%) \\
24 \text { a } 32 \text { horas: } 2(12,5 \%)^{11}\end{array}$ & $\begin{array}{l}\text { média total: } 18 \text { horas } \\
0 \text { a } 8 \text { horas: } 1(12,5 \%) \\
9 \text { a } 16 \text { horas: } 2(25 \%) \\
17 \text { a } 24 \text { horas: } 3(37,5 \%) \\
24 \text { a } 32 \text { horas: } 2(25 \%)^{12}\end{array}$ \\
\hline $\begin{array}{l}\text { Cursos de } \\
\text { atuação } \\
\text { na IES }\end{array}$ & $\begin{array}{l}\text { Controladoria e Finanças: } \\
1 \text { docente }(6,25 \%) \\
\text { Gestão Estratégica de Pessoas: } \\
4 \text { docentes }(25 \%) \\
\text { Marketing de Varejo: } \\
3 \text { docentes }(18,75 \%) \\
\text { Responsabilidade Social Empresarial e } \\
\text { Sustentabilidade: } \\
8 \text { docentes ( } 50 \%) \\
\text { Foram oferecidos } 10 \text { cursos de pós- } \\
\text { graduação lato sensu no semestre da } \\
\text { pesquisa pela IES }\end{array}$ & $\begin{array}{l}\text { Gestão Estratégica de Pessoas: } \\
3 \text { docentes }(37,5 \%) \\
\text { Marketing de Varejo: } \\
2 \text { docentes }(25 \%) \\
\text { Responsabilidade Social Empresarial e } \\
\text { Sustentabilidade: } \\
3 \text { docentes }(37,5 \%) \\
\text { Foram oferecidos } 10 \text { cursos de pós- } \\
\text { graduação lato sensu no semestre da } \\
\text { pesquisa pela IES }\end{array}$ \\
\hline $\begin{array}{l}\text { Dedicação } \\
\text { exclusiva } \\
\text { à docência }\end{array}$ & $\begin{array}{l}\text { sim: } 3 \text { docentes }(18,75 \%) \\
\text { não: } 13 \text { docentes }(81,25 \%) \text {, sendo } 7 \\
\text { consultores }\end{array}$ & $\begin{array}{l}\text { não: } 6 \text { docentes }(75 \%) \text {, sendo } 4 \\
\text { consultores }\end{array}$ \\
\hline
\end{tabular}

Fonte: Dados da pesquisa on-line desta dissertação, coletados em 2016.

\footnotetext{
${ }^{11}$ Um dos docentes dedica 40 horas semanais à IES, sendo 20 em sala de aula.

${ }^{12}$ Igualmente, um dos docentes trabalha 40 horas semanais na IES, 20 das quais em sala de aula.
} 
Esses resultados são coerentes entre si: os dados do total de docentes do lato sensu da IES, com os do Grupo A, de 16 docentes respondentes da pesquisa prévia on-line, e também com os do Grupo B, de oito docentes entrevistados, confirmando a recorrência de informações das múltiplas dimensões do objeto de estudo.

As categorias que apresentaram certas diferenças foram a formação acadêmica - mais diversificada no Grupo A - e as horas de dedicação semanal à docência: apesar das médias próximas (14 horas no Grupo A e 18 horas no Grupo B), a maior parte dos docentes do Grupo A dedicava até oito horas semanais, enquanto, no Grupo B, a maioria dedicava de 17 a 24 horas, o que talvez explique sua maior disposição para participação na pesquisa.

A análise dos dados mostra que 37,5\% do Grupo A e 33,5\% do Grupo B eram mulheres, que em ambos os grupos 12,5\% tinham mais de 60 anos, $25 \%$ eram doutores, 31,25\% do Grupo A e 38\% do Grupo B eram contratados pela CLT e 18,75\% do Grupo A e $25 \%$ do Grupo B dedicavam-se exclusivamente à docência. Esses são os dados que representam a minoria em cada um dos dois grupos de amostras de docentes.

Por outro lado, a maioria dos participantes eram homens (62,5\% do Grupo A e $66,7 \%$ do Grupo B), com idade entre 30 e 39 anos (43,75\% do Grupo A e $37,5 \%$ do Grupo B), com titulação de mestre ou de especialista (37,5\% de cada grupo), contratados como convidados por tempo determinado ou carta-convite $(68,75 \%$ do Grupo A e $62 \%$ do Grupo B) e exercem outra atividade profissional além da docência (81,25\% do Grupo A e $75 \%$ do Grupo B), sobretudo como consultores corporativos. Esses dados são coerentes com o último Censo da Educação Superior 2014, realizado pelo INEP (2016) e respondem às orientações de titulação do MEC ([s.d.]b), conforme apresentado no Capítulo 1.

Observamos que os pontos críticos dessa maioria são o tipo de contratação por tempo determinado (por carta-convite) e a atuação em outras atividades além da docência. Ambos podem comprometer a dedicação do docente em questões relevantes, tanto educacionais como acadêmicas, como a pesquisa e a formação continuada. A contratação obedece ao número de horas-aula, isto é, qualquer ação 
extra é feita por investimento próprio, apesar da já restrita disponibilidade, normalmente comprometida pela outra atividade.

No Grupo B da amostra de oito docentes entrevistados, apesar de a média geral de idade de ser 45 anos, a maior parte (37,5\%) tem de 30 a 39 anos. Mesmo a maioria sendo convidada por tempo determinado (carta-convite) e tenha outra profissão, 37,5\% dedicam de 17 a 24 horas semanais à docência, e a média geral do grupo é de 18 horas. Isso mostra um compromisso considerável para cursos lato sensu ou que muitos lecionam em mais de um curso.

O tempo médio de docência dos sujeitos é de 13 anos, observando que $62,5 \%$ têm até 10 anos de trabalho. Mas esse foi o aspecto mais heterogêneo do grupo, porque $25 \%$ têm até 5 anos, $37,5 \%$ de 6 a 10 anos, $12,5 \%$ de 11 a 20 anos, $12,5 \%$ de 20 a 30 anos e 12,5\% mais de 30 anos. Esse resultado pode subsidiar a reflexão sobra heterogeneidade dos saberes experienciais desses docentes.

Outro aspecto interessante é que $75 \%$ dos docentes são graduados em Administração de Empresas e $50 \%$ são mestres ou doutores também em Administração. Já as especializações (lato sensu) são coerentes com o curso e a

disciplina que os docentes lecionam: Responsabilidade Social Empresarial e Sustentabilidade (37,5\%), Gestão Estratégica de Pessoas $(37,5 \%)$ e Marketing de Varejo (25\%).

A partir dos dados colhidos na pesquisa, traçamos um breve resumo do perfil profissional dos oito docentes entrevistados, que traz informações relevantes sobre a identidade docente para a análise posterior dos saberes pedagógicos. Os docentes foram numerados de 1 a 8 e organizados de acordo com o tempo de docência.

\section{Docente 1 (D1) - 40 anos}

Leciona há três anos, é graduado e mestre em Administração e está cursando o doutorado. Até 2012, trabalhava como executivo de empresa; a partir daí, ingressou no mestrado e, paralelamente, foi convidado a ser docente. 
Ministra cursos de MBA desde 2013, como docente contratado pela CLT em outra IES de São Paulo. Atualmente, é professor convidado da IES selecionada, assim como consultor e facilitador de treinamentos para executivos.

Docente 2 (D2) - 32 anos

Leciona há cinco anos, é graduado em Administração e especialista em Finanças. Pretende cursar o mestrado para aprimorar o "olhar sobre a educação", pois iniciou a docência baseado em habilidades na condução de treinamentos corporativos.

Toda a sua atuação como docente foi na pós-graduação lato sensu da IES selecionada, lecionando em duas a três turmas por ano. É também gestor em uma empresa.

Docente 3 (D3) - 36 anos

Leciona há seis anos, é graduada em Administração, especialista em Qualidade e tem MBA em Gestão de Pessoas. Desenvolve a docência presencialmente e a distância (EAD), em pós-graduação lato sensu em três unidades da IES.

É contratada como horista pela CLT na IES selecionada, ou seja, trabalha entre uma e 19 horas semanais, de acordo com a necessidade da instituição. Trabalha também como consultora em gestão empresarial.

\section{Docente 4 (D4) - 42 anos}

Leciona há oito anos, é graduado em Jornalismo e mestre em Marketing. Iniciou sua atividade em 2008, dando aulas na graduação, e em 2013, no lato sensu, ambos em outra IES de São Paulo. 
Atualmente, está cursando o doutorado, é professor contratado pela CLT na graduação e pós-graduação em de outra IES de São Paulo, além de atuar no lato sensu da IES selecionada como convidado e ser consultor de empresas.

Docente 5 (D5) - 32 anos

Leciona há nove anos e foi convidado devido à experiência profissional na área de especialização. É graduado em Economia, especialista em Gestão de Marketing e Gestão de Negócios e pretende iniciar, em breve, o mestrado.

Todas as experiências como docente foram em cursos lato sensu como professor convidado. Além de docente convidado na IES selecionada, é diretor de uma empresa.

Docente 6 (D6) - 56 anos

Leciona há 14 anos, é graduada em Administração e Pedagogia, especialista em Docência no Ensino Superior e mestre em Administração.

Começou a docência paralelamente à carreira corporativa, trabalhando em cursos de graduação e de pós-graduação em diferentes IES da cidade de São Paulo. Hoje, é docente contratada pela CLT da IES selecionada, consultora educacional e profissional.

Docente 7 (D7) - 57 anos

Leciona há 29 anos, é graduado em Administração, especialista em Administração de Recursos Humanos, mestre em Administração e doutor em Serviço Social. Durante parte da carreira, atuou em treinamento e desenvolvimento humano em empresas e foi consultor corporativo. 
Trabalhou durante anos na IES selecionada como professor convidado, tendo sido contratado pela CLT em regime de tempo integral. Atualmente, é docente e coordenador de cursos lato sensu, além de conduzir projetos na IES.

\section{Docente 8 (D8) - 64 anos}

Leciona há 34 anos, é graduado e mestre em Administração e doutor em Semiótica. Sua atuação empresarial foi apenas no começo da carreira.

Hoje, é professor aposentado por uma IES pública e, há sete anos, leciona como convidado em várias IES privadas, incluindo a que estudamos aqui.

Baseados nessas informações, observamos como aspectos convergentes: a forte presença da área de administração de empresas na formação dos docentes, a experiência prévia em organizações que impulsionou o início na docência e a carreira atual dividida entre a docência e a atuação empresarial.

Um ponto que se destaca é a dedicação exclusiva à docência, encontrada apenas nos relatos do D7 e do D8, justamente os que têm mais experiência como professores e ambos doutores.

Esses dados são importantes para analisarmos os saberes pedagógicos discutidos a seguir, subsídios para a análise e a reflexão dos docentes e da IES.

\subsection{Saberes pedagógicos dos docentes do lato sensu da IES selecionada}

A partir do perfil dos docentes do lato sensu obtido pelas respostas ao questionário on-line, foi desenvolvido o roteiro semiestruturado (Apêndice B) para as entrevistas.

A maioria das pesquisas qualitativas dão prioridade a entrevistas semiestruturadas, tornando-as um procedimento de coleta de dados amplamente 
adotado na área da educação. Nesse caso, são necessários cuidados com a linguagem, e o roteiro deve ser previamente preparado (Manzini, 2012). A entrevista é um procedimento de coleta que explora um tipo específico de dado, que é a versão sobre fatos - exatamente a busca desta pesquisa.

Para Triviños (1987), a entrevista semiestruturada é caracterizada por questionamentos básicos apoiados em teorias e hipóteses relativas ao tema da pesquisa, com o foco principal no investigador-entrevistador. $O$ autor complementa que "[...] favorece não só a descrição dos fenômenos sociais, mas também a explicação e a compreensão da totalidade [...]", além de manter a presença consciente e atuante do pesquisador no processo de coleta de informações (Triviños, 1987, p. 152).

Consequentemente, a coleta de informações foi planejada por meio de um roteiro com perguntas abertas e uma flexibilidade que permitisse a interação entre pesquisador e entrevistado e também perguntas complementares de acordo com a necessidade.

Com o consentimento dos participantes (Anexo), as entrevistas foram gravadas e depois transcritas para análise e categorização, o que faculta verificar a autenticidade e resgatar detalhes das falas, além de conferir credibilidade científica à análise dos dados.

O tempo das entrevistas, assim como o volume e qualidade das informações coletadas variaram segundo a disponibilidade e experiência de cada docente. Com duração média de uma hora, a entrevista mais breve levou 33 minutos e a mais longa, uma hora e 32 minutos.

Os resultados obtidos com os docentes do lato sensu da IES na investigação de seus saberes pedagógicos foram cuidadosamente examinados e organizados nas seguintes categorias de análise:

3.3.1 Cursos lato sensu e identidade docente

3.3.2 Formação e desenvolvimento docente

3.3.3 Saberes pedagógicos e prática docente

3.3.4 Papel dos saberes pedagógicos e autorreflexão docente 
As informações relevantes para este estudo são apresentadas a seguir, conforme essas quatro categorias.

\subsubsection{Cursos lato sensu e identidade docente}

Durante as entrevistas individuais, os docentes foram perguntados sobre como percebem os cursos lato sensu, as expectativas dos alunos e o seu próprio papel como docente, antes de iniciar a reflexão sobre os saberes pedagógicos.

A visão sobre o objetivo dos cursos lato sensu foi explicada claramente por três docentes. O D7 resgatou a criação e a natureza desses cursos como resposta à demanda de mercado, e observou que eles ainda mantêm o propósito da capacitação voltada para a prática profissional de suas respectivas áreas de conhecimento, como afirmaram também a D3 e o D5. Aliás, esses são três docentes de um mesmo curso da IES selecionada, aspecto que pode ter facilitado essa percepção comum.

Tem uma questão histórica aqui no programa do lato sensu, que é como ele foi criado, para que ele foi criado. Então, [...] ele responde a uma demanda bastante localizada do mundo do trabalho, no atendimento às necessidades do mundo do trabalho, à necessidade de formação continuada. A gente não pode perder isso de vista (Docente 7, 57 anos).

O lato sensu é um curso preparado, desenvolvido para um aluno [...] que quer saber quais são as ferramentas que ele pode usar para resolver os problemas dele do trabalho (Docente 3, 36 anos).

No lato sensu, você quer alguma coisa prática para que você possa implementar seu dia a dia. Ou pelo menos que te ajude a tomar uma decisão estratégica na sua rotina profissional (Docente 5, 32 anos).

Como vimos, para Bosi (2007) e Chaves (2010), o processo de mercantilização do ensino superior brasileiro e, consequentemente, sua massificação, gerou um questionamento sobre a qualidade dos cursos e o ensino dos docentes de lato sensu, mencionado pelo D2 e pela D6.

Vejo isso até como uma exigência do mercado. O mercado exige muito do aluno, que você tenha a formação, que você tenha o papel [certificado]. Infelizmente, com isso, talvez não tenha aumentado a qualidade. As universidades disponibilizando cursos com conteúdos muito superficiais, mas muito com a questão comercial, ponto de equilíbrio receita e despesa, "preciso de receita para pagar minhas despesas...". [...] Oferecendo cursos que, em alguns momentos, você 
não tem professores totalmente qualificados. Isso eu vi na experiência e até por relatos de alunos também (Docente 2, 32 anos).

Mas aquilo me entristeceu tanto [...] que cheguei a pensar assim: "Onde eu estou entrando?" [...] A instituição (não a selecionada para esta pesquisa) queria ganho de eficiência com redução de custos de infra e custos de pessoas, efetivamente hora/professor. Aí, a gente chegou a um consenso de que iríamos fazer uma análise [...] Nesse momento, a instituição começa a "patinar", porque, no entender dela, aquilo ali já era suficiente, e eu, com aquela preocupação com a qualidade, falei: "Gente, nós temos cuidado com os conteúdos para que eles sejam atemporais, mas a gente está lidando com algo muito dinâmico. Logo mais, os alunos estão acessando estudo em celular. A mesma velocidade, a mesma atualização eles vão querer nas suas maquininhas de mão. Não dá para a gente pensar só em custo". E a instituição tinha uma resistência muito grande com relação a isso. Aí, a qualidade do produto começou a cair (Docente 6, 56 anos).

Nesse cenário, os mesmos docentes (D2 e D6) argumentaram que a duração de cada disciplina dos cursos lato sensu é curta, com seis a oito aulas distribuídas em torno de um mês e meio. Esse é um aspecto desafiador para garantir a aprendizagem prevista dos alunos. Apesar de representarem 25\% do grupo, essas preocupações precisariam ser melhor exploradas.

Como essas pessoas vão se aprofundar em seis aulas para que elas possam entender a matéria? (Docente 2, 32 anos).

Eu tenho disciplinas com seis aulas ou com oito aulas, então, um mês e meio para cumprir desde a apresentação do conteúdo, a avaliação etc. É um tempo muito curto (Docente 6, 56 anos).

Segundo o D5, os cursos lato sensu favorecem o networking ${ }^{13}$ entre os alunos, o que é considerado um diferencial num ambiente com foco profissionalizante. Já para o D7, o pragmatismo esperado no lato sensu apresenta um cenário com variáveis críticas que devem ser analisadas cuidadosamente. Por exemplo, a informalidade do processo avaliativo dos alunos (citada pelo D5) e a remuneração salarial abaixo do esperado (relatada pelo D8), esta questionada desde a década de 1970, devido ao barateamento da mão de obra (Bosi, 2007). Por isso, o D8 sugeriu a mobilização dos docentes para a reversão desse quadro. Porém, antes disso, seria necessário existirem situações que promovessem a construção de relações entre os docentes do lato sensu na IES, que hoje são apenas pontuais e facultativas.

\footnotetext{
${ }^{13}$ Networking: termo em inglês que designa a capacidade de estabelecer uma rede de contatos ou uma conexão com alguém com o objetivo de criar novos relacionamentos profissionais.
} 
Então, a pós [lato sensu] acaba te ajudando muito a dar um direcionamento a sua carreira. E acaba criando um networking entre os alunos. Na última turma, tinha só uns três com nível maior e uma grande parte que a gente chama de coordenador, analistas sênior, pleno e júnior. Diferente do MBA, que são cargos mais altos (Docente 5,32 anos).

Uma expectativa real da sociedade, quando contrata ou quando se tenta sentar na cadeira do lato sensu, é certamente porque ele quer ouvir daquele professor que está lá na frente como é que se resolve um problema. [...] No lato sensu, isso é constante. Dentro da sala de aula, a gente joga o mundo do trabalho para lá, tenta elevar o nível de compreensão e consciência sobre a dada realidade, aí o mundo do trabalho retorna para a gente como uma demanda. Esse jogo dentro da sala de aula é algo que eu acho, talvez, esteja muito presente, e, tendo trilhado o caminho do stricto sensu no mestrado e no doutorado, eu acho que tem uma diferença, mesmo. Por isso o lato sensu é tão crítico, e é uma pena que ele seja tão pouco olhado (Docente 7, 57 anos).

Eu gosto bastante do lato sensu, eu acho que é uma maneira menos formal, talvez, de você ter aproximação do conhecimento mesmo. [...] Até porque não te exige tanto como fazer uma prova final ou um trabalho de conclusão de curso muito profundo, dependendo da IES (Docente 5, 32 anos).

No lato sensu, era $\mathrm{R} \$ 110,00$ a hora. Isso é uma injustiça. Veja quanto tempo demorou para eu chegar a uma sala de aula e falar sobre o tema, olha para trás e vê o que tem. Por isso, tem que ser regiamente pago. Os colegas precisavam ser mais unidos. Tudo isso, quando você entra na sala de aula em uma IES, querem te pagar uma merreca, querem te pagar um valor baixo, de modo geral. Por amor, você aguenta determinado tempo, mas depois você precisa comer (Docente 8, 64 anos).

Em relação à IES selecionada, os docentes entendem que ela visa o desenvolvimento profissional do aluno e que isso é coerente com a demanda dos alunos que esperam um aprendizado pragmático imediatamente aplicável ao mercado profissional, e com o posicionamento institucional da própria IES.

Eu vejo que a IES tem uma direção para a "ferramenta". Amanhã, o aluno vai sair da empresa dele e vai fazer isso (Docente 1, 40 anos).

A pós-graduação [lato sensu] na IES é como um "quintal da empresa", [...] em que eles buscam o certificado para, em princípio, poder ter alguma promoção ou poder colocar o papel [certificado] dele dentro da empresa. Basicamente, é isso (Docente 2, 32 anos).

O aluno quer chegar aqui na IES, olhar para mim: "como eu faço?" Eu até brinco com eles que "assim, é receita de bolo que vocês vieram buscar. Tudo bem, a gente pode até dar uma receita, mas, não é a proposta". [...] Mas eles veem com essa expectativa do aprender a fazer (Docente 6, 56 anos).

Esta IES tem claramente a sua vocação direcionada para o mundo de trabalho, para o mundo do empreendedorismo. [...] Seja quem for esse 
aluno, ele vem buscar uma solução pragmática, olhando para aquele professor na frente dele (Docente 7, 57 anos).

O D1 foi quem demonstrou a percepção mais positiva sobre a IES. Falou sobre sua satisfação de lecionar na instituição, que valoriza o papel do docente e promove sua autonomia com responsabilidade. Alinhada a essa visão, a D6 afirmou que a IES possui uma boa reputação do mercado.

Acho que o papel do professor na IES é valorizado. Eu me sinto responsável pelo desenvolvimento daqueles meninos [alunos]. A IES [...] dá bastante liberdade ao docente. Então, basicamente, a coordenadora me deu o nome da disciplina, me passou a ementa e me pediu para montar o programa. E aí teve algumas idas e vindas. Tem faculdade que não dá responsabilidade, ela larga tudo e aceita qualquer coisa. A IES é um dos lugares em que eu gosto de dar aula (Docente 1, 40 anos).

Bom, eu vou falar especificamente do meu curso. Eu acredito, e consigo comprovar isso no cotidiano da sala de aula, que o nome da IES tem um peso. Então, o pedigree, a marca [...] é reconhecida como uma marca boa, e a pessoa que a procura ou quem recomenda, na verdade, tem uma preocupação de aprender a fazer (Docente 6, 56 anos).

O papel do coordenador do curso foi reconhecido pelo D1 pela importância de seu acompanhamento e por sua disponibilidade, que, no seu caso, apoiou seu desejo de desenvolver o pensamento crítico dos alunos a partir da experimentação de metodologias ativas. O D5 destacou a orientação prévia da coordenação, que contribuiu com a preparação da disciplina, reputando a IES melhor do que as demais em que trabalhou. Poucos docentes comentaram experiências com os seus coordenadores, situação que mereceria ser verificada pela IES.

Não sei quanto é da IES ou da coordenadora, porque só tenho contato com ela, mas achei que ela me deu muita liberdade, me deu apoio. E, até um pouco pela característica do aluno da instituição, eu propus algumas metodologias ativas que ela [coordenadora] disse que não eram usuais na IES, mas ela "comprou". Ela me questionou sobre quanto eu estaria à vontade, quanto estaria preparado, falou "vai e me conta como foi". Achei muito legal! Aí, como professor, se eu tenho mais autonomia, também tenho muito mais responsabilidade, porque estou propondo e fazendo do meu jeito. Também me sinto acompanhado de um jeito muito legal. Um coordenador disponível, interessado - e não é cobrança, é acompanhamento. É parceria [...]. Me sinto bem acolhido (Docente 1, 40 anos).

A conversa com o coordenador foi mais madura, em termos do que ele gostaria como módulo. Ele tinha muito um norte do que seria esse módulo. As outras instituições dão muita liberdade. Não que ele me desse para fazer do jeito que quisesse, mas ele tinha uma demanda. 
Nas outras IES, pode falar o que você quiser sobre o tema (Docente 5,32 anos).

Como sugestões de melhoria à IES, o D4 comentou que a remuneração do docente é inferior à das demais da cidade, e a D6 mencionou a organização curricular dos cursos lato sensu, em que a sequência das disciplinas fica sujeita à disponibilidade dos docentes, e não necessariamente em função do interesse pedagógico, como recomenda Masetto (2003).

Quanto ao conteúdo, eu já tive oportunidade de ver o curso na totalidade, e algumas sugestões eu cheguei a fazer até para mudar a ordem das disciplinas. Mas, ainda assim, ele tem que ter uma lógica toda própria e defensável. Então, a gente fez alguns "ajustezinhos", mas ainda há coisas a ajustar. Tem algumas disciplinas que são oferecidas no final e que seriam prioritariamente de início ou de meio de módulo. É mais uma questão de calendário dos professores do que de didática (Docente 6, 56 anos).

A maioria dos docentes afirmou que os alunos desses cursos têm perfis muito diferentes, sobretudo no tange à formação acadêmica. Segundo o D1 e o D2, na IES pesquisada, a formação dos alunos é defasada. Para o D4, o D5, a D6 e o D7, essa diversidade enseja o grande desafio de estruturar um ensino que resulte em aprendizagem. E o D4 e o D5 afirmam que essa variedade se estende à experiência dos alunos, o que pode mudar de acordo com a turma, segundo o D7.

Mas o pior de tudo é que tem só a embalagem, o recheio não existe. [...] A maioria das pessoas em nosso país tem um gap que vem lá de trás. [...] Talvez isso seja até uma questão cultural do país: as pessoas se preocupam muito mais com o status, com o papel, do que com o recheio (Docente 2, 32 anos).

É heterogênea. Às vezes, pra mim, isso "pega" um pouquinho no lato sensu. Tem gente entrando no mercado de trabalho, ou que nem está no mercado de trabalho (não que está desempregado, mas que nem entrou mesmo, mal terminou a faculdade e agora vai especializar) e tem pessoas com uma bagagem e até um conhecimento sobre o tema acima da média. Além de terem formações muito diferentes (Docente 5,32 anos).

Nossas salas são extremamente heterogêneas. Eu tenho diversas formações, e compatibilizar isso nem sempre é fácil, porque, embora você tenha um plano de ensino, você tem até material pronto, mas cada turma é uma aventura, porque você tem que retomar aquilo tudo... (Docente 6, 56 anos).

A formação da turma do curso é heterogênea. [...] Cada turma é diferente da outra. A gente vai trabalhando com os alunos, senta com eles sempre no primeiro dia, explica o plano de ensino, como é que a gente está pensando. [...] Então, uma vez, tive uma sessão boa de 
debate com os alunos e falei "na própria formação da turma, a gente privilegiou a heterogeneidade, porque a gente quer o plural em sala de aula e a gente tem que lidar com esse plural." (Docente 7, 57 anos).

A percepção do D8 é de que esses alunos têm uma média de 25 anos, o que não representa a realidade observada em todos os cursos. Sabemos que, na IES selecionada, profissionalmente, eles ocupam cargos mais técnicos do que de liderança e procuram crescer na carreira, o que é confirmado pelo D2, pela D3, pelo D5 e pelo D8.

Tanto no lato sensu como no MBA tem essa disparidade. Qualquer curso, independentemente [...] tem pessoas com diferença de perfil. Com relação à idade, como eu venho ministrando aulas na pósgraduação [lato sensu], o que eu tenho observado? Esses alunos do lato sensu vêm cada vez mais jovens para o curso. [...] Hoje, você vê o pessoal na faixa de 25 , quer dizer, praticamente termina a graduação e já emenda (Docente 8,64 anos).

Eu vejo muito o lato sensu para esse pessoal, que está [numa empresa] de analista para cima, que já está num nível mais técnico, querendo subir para cargos de coordenação e supervisão (Docente 3, 36 anos).

Você tem os sonhadores, aqueles que estão mudando a carreira e que a enxergam como ideal. Outros que já trabalham com o tema de alguma forma, e se interessaram até para entender o que essa carreira proporciona, quer se aprofundar no tema. Vejo muito isso na pós lato sensu. [...] Inclusive, aconteceu comigo. Aconteceu isso de mudar a carreira (Docente 5, 32 anos).

Para a 75\% dos entrevistados (D1, D3, D4, D6, D7 e D8), as expectativas dos alunos são relativas aos saberes disciplinares e experienciais dos docentes, para obterem a aprendizagem pragmática. O D7 explica que desejam inspirar-se no docente, que pode inclusive apoiá-los com aconselhamento.

Os alunos, todos eles, têm algumas coisas em comum e, entre elas, é essa questão de querer saber se você, professor, já fez na prática. "Então, se você já fez na prática, me conta quais foram as dificuldades, me conta quais foram os caminhos que você utilizou". Eles querem exemplos de quais projetos você já teve, como foi esse projeto, como foi conversar com a diretoria, como foi engajar os funcionários. São sempre essas as principais dúvidas (Docente 3, 36 anos).

Frequentemente, ainda prevalece no ensino, especialmente na formação dos profissionais que estão ligadas ao mundo empresarial, ainda prevalece muito a questão técnica, pragmática, o reducionismo do conhecimento ainda infelizmente ocorre. [...] Diferente do stricto sensu, o mundo prático do trabalho é trazido pelo aluno o tempo todo [...] Quando eles vêm, eles vêm buscar um pouco dessa informação. Olham para o professor como uma área de conhecimento rica o 
suficiente até para dar uma certa consultoria, um certo coaching (Docente 7, 57 anos).

É um pessoal pragmático, eles têm interesse em absorver, porque precisam apresentar resultados no trabalho, além de ter o diploma para melhorar o currículo (Docente 8, 64 anos).

Um depoimento que merece atenção a esse respeito é o da D6, para quem alguns alunos nem sempre sabem o que esperam. Além disso, ela questiona os critérios do processo seletivo da IES. Esse é um ponto crítico nos cursos lato sensu, que não são objeto desta pesquisa, mas que mereceriam uma investigação acurada.

Alguns vêm buscar o certificado por exigência do trabalho. Alguns falam: "Olha, eu preciso me preparar melhor". Mas ele não sabe bem o que veio fazer. Eu tenho de tudo um pouco, mas, como eu tenho que acolher todo mundo, uma das coisas que eu sinto é assim: não há um processo seletivo que promova uma homogeneidade da turma, e creio até que isso tenha as razões institucionais. Mas, não sei se é esse o critério, eu não posso afirmar (Docente 6, 56 anos).

Em nenhum momento foi mencionada a preocupação com o cumprimento de regras ou padrões da IES, nem quanto a regulamentos ou à avaliação do MEC ou de outra instituição quanto à disciplina, ao curso ou à atuação docente. Segundo a IES, existe uma comissão própria de avaliação, mas, além de os entrevistados não a haverem citado, eu mesma, docente convidada há sete anos na IES, nunca presenciei a sua aplicação, o que pode confirmar a fragilidade regulamentar desses cursos lato sensu em relação à atuação docente.

A percepção sobre a identidade docente do lato sensu é de que a maioria são convidados temporariamente (carta-convite), e não contratados por CLT, segundo o depoimento de três entrevistados (D1, D5 e D8), o que é coerente com o dado informado pela IES pesquisada, de que são no lato sensu $68,75 \%$. Porém, para o D7, existe uma combinação entre os dois tipos de contratação (CLT e convidado).

Acho que, na graduação [...] normalmente os professores são contratados. Na pós [lato sensu], tem muito professor que trabalha como convidado, porque ele trabalha em outras empresas (Docente 1, 40 anos).

O docente tem de ser responsável e saber o que está fazendo, pra não virar "charlatão". Esse é um risco que vejo em alguns lato sensu ou na maioria deles, principalmente nessa área de conhecimento. Porque você não vai ter vários celetistas no mesmo curso na instituição. Então, você chama muito no mercado os especialistas (Docente 5, 32 anos). 
Tem muita coisa em comum e que se repete nos cursos lato sensu, principalmente nas IES privadas. Dou aula e fiz pós em uma e também tenho alguns colegas que dão aula, e a gente vê que, na pósgraduação lato sensu, [...] a gente tem uma porcentagem bem pequena de celetistas contratados: a maioria é temporário, com cartaconvite (Docente 8, 64 anos).

A formação da turma e dos docentes do curso é heterogênea. [...] Existe uma mescla de docentes contratados e convidados (Docente 7 , 57 anos).

Esse cenário confirma a flexibilização dos contratos trabalhistas, que é reflexo de um sistema educacional produtivista, segundo Bosi (2007). Sem dúvida, o tipo de contratação influi em questões relevantes para a qualidade do trabalho docente.

O D1, o D5, o D7 e o D8 (50\% dos docentes) concordaram que são os saberes disciplinares e experienciais relativos à área de atuação empresarial que levam os docentes a serem convidados a lecionar no lato sensu, motivo que levou o D1 a questionar o nosso sistema educacional.

Então, eu entendo muito sobre a área profissional e eu conheço os autores de referência. Eu acho que muita gente vai pra frente só com isso. Tem alguma coisa errada no nosso sistema (Docente 1, 40 anos). Acaba ficando muito a cargo dos especialistas ou de quem está nessa área para ajudar os alunos a compreenderem um pouco sobre o tema. Enfim, sempre fui convidado a lecionar por conta disso (Docente 5, 32 anos).

Quem são os docentes do lato sensu? A partir da minha própria experiência, quer dizer, eu sou convidado a ser docente num momento em que eu sou executivo. Se você tem muito docente convidado, que você está convidando pela especialidade dele, certamente ele não passeou nessa praia, então, ele vai entrar na sala e vai ser aquela aula de que agora há pouco a gente falava, que era voltada para a prática (Docente 7, 57 anos).

O D1, que é convidado pela IES estudada e contratado pela CLT em outra IES de São Paulo, complementou que esse vínculo temporário compromete a participação em ações educacionais e pedagógicas que, por serem realizadas fora do horário de aula e por não serem obrigatórias, dependem do investimento pessoal do docente convidado. Inclusive, essa percepção faz o D1 questionar a identidade docente nesse contexto. Muito oportunamente, o D8 lembrou que esse tipo de contratação exige um intervalo entre as turmas, para não envolver a IES em questões trabalhistas, o que leva o docente convidado a lecionar em mais de uma instituição simultaneamente, comprometendo a seu trabalho. 
Então, a IES não pode obrigar o professor a participar de ações [de formação]. Ele está lá como professor, mas nem sempre ele é tão professor (Docente 1, 40 anos).

Terminou, inclusive, há duas semanas, e agora não posso mais dar curso porque tenho que esperar. Por isso, o ideal é você ficar em duas ou três escolas. [...] Mas é "puxado". Você pega segunda e quarta, e o outro terça e quinta - foi o que o já aconteceu comigo -, logo em seguida. O que não pode é caracterizar você voltar no semestre seguinte - senão, falam que você tem vínculo (Docente 8, 64 anos).

Do ponto de vista da D6, que é contratada por CLT na IES, lecionar em poucos cursos simultaneamente é essencial para que se tenha tempo de revisar e atualizar a disciplina, garantindo a melhor preparação da aula.

Eu estou só em um curso, até porque eu entendi que, na pósgraduação [lato sensu], [...] você precisa ter uns intervalos de tempo para se refazer, para remontar as coisas. [...] Aí, eu mesma optei por segurar um pouco. Não vou me "afundar" (Docente 6, 56 anos).

A heterogeneidade não caracteriza apenas as turmas de alunos, mas também o conjunto dos docentes do lato sensu. O D7 apontou uma diversidade de formações acadêmicas entre os professores e considera isso um aspecto positivo. Essa ideia é confirmada pela pesquisa on-line realizada antes das entrevistas, que revelou, sobre a amostra de oito docentes: três áreas de graduação, cinco áreas de especialização e quatro áreas de formação stricto sensu.

Devido às expectativas dos alunos e o propósito da IES, consideram responsabilidade dos docentes mostrar aos alunos a aplicabilidade de sua aprendizagem no mercado de trabalho. O D2 explicou que antes precisa conseguir despertar o interesse deles para depois estimulá-los a tomar decisões empresariais. E, para a D3, os alunos devem primeiro entender os conceitos e os processos para depois saberem "escolher a ferramenta" mediante a situação.

O meu papel é disseminar, de certa forma, que o que a gente está explicando ali seja lembrado no mundo profissional. [...] Como vou fazer para trazer assuntos que não são inerentes à atividade profissional dessas pessoas, sem que também fique algo muito técnico? Acho que a missão do docente, a expectativa é nesse sentido. Criar aquela "sementinha" lá, fazer com que o aluno em algum momento tenha interesse por aquilo que ele está te dizendo ou para que se lembre [do que aprendeu] na tomada de decisão na empresa (Docente 2, 32 anos).

Eu acho que as minhas cobranças são [...] um bom embasamento teórico, uma boa contextualização dos temas, das disciplinas que eu 
abordo, o "ferramental" que eu sei que para eles é importante. Mas, sem antes passar por essa contextualização (porque eles são bem ansiosos com o ferramental e sempre dedicam muito tempo das aulas a isso) [...] sem entender o processo, sem entender a contextualização, não adianta ter uma caixa forrada de ferramentas, porque eles não vão saber em cada situação qual a melhor ferramenta (Docente 3, 36 anos).

O desenvolvimento dos seus saberes disciplinares e experienciais é priorizado pela D3 e pelo D5, devido ao objetivo dos cursos lato sensu em que atuam.

As perguntas são sempre essas: se você tem domínio do assunto e se você já fez isso na prática. A gente acaba servindo de referência para eles cada vez que precisam de alguma coisa ou quando eles têm alguma dúvida (Docente 3, 36 anos).

Quando você procura o lato sensu, você quer alguém que saiba mais que você. Esse é um ponto em que eu me frustrei como aluno. Então, sempre que vou dar aula, procuro autores fora do comum, casos de outros setores e de várias empresas (Docente 5, 32 anos).

Um aspecto relevante nos depoimentos dos entrevistados é que todos relacionaram seu papel e suas responsabilidades à aprendizagem do aluno. O D4 e a D6 apontaram a necessidade de entender seu conhecimento prévio e suas expectativas.

Eu levo umas duas aulas para tentar entender "em que pé" a turma está, e essa na verdade é uma das minhas principais preocupações: nem avançar demais, para que uma parte da turma definitivamente não entenda do que estou falando, e nem levar um conteúdo raso, para todo mundo olhar e falar "poxa, isso estou cansado de ver" (Docente 4, 42 anos).

Então, eu acho que o meu papel é esse mesmo, de tentar identificar as expectativas deles [alunos] e tentar atender à medida do possível o que eu posso, o que eu entendo (Docente 6, 56 anos).

Segundo o D4, seu esforço é para garantir que todos acompanhem os conceitos, mesmo com diferentes formações e conhecimentos. O D5 percebe a aula como um espaço de troca de conhecimento e incentivo à autonomia do aluno. Finalmente, a D6 entende seu papel como o de facilitadora da aprendizagem, independentemente do progresso e do número de alunos envolvidos, o que é confirmado pelo "brilho no olhar".

Devido à heterogeneidade, é o ponto mais delicado, perceber até onde eu posso avançar sem deixar muita gente para trás, mas também levar a galera um passo adiante daquilo que eles esperam. Porque também, se eles não se surpreendem nada. Percebo que o aluno de pós, 
especificamente lá da IES estudada, parece que eles querem saber se a gente sabe mesmo (Docente 4, 42 anos).

O grande papel do professor é conectar saberes. Você pega o livro [...] com um monte de artigos que estavam na bibliografia - eu acho que o grande papel do professor é unir essa técnica e chegar a uma lógica. O professor, ele não está ali só pra ganhar ou, enfim, ter uma remuneração. Ele está ali pra compartilhar conhecimento e quer fazer diferença para os alunos (Docente 5, 32 anos).

Por isso eu sempre falo que o meu papel com os alunos é tentar fazer com que eles avancem esse "um metro". Se for só $2 \%$, já terá valido. A interiorização do aprendizado se expressa no olhar do aluno. É aquele momento em que [...] brilha o olho dele numa frase, numa imagem, numa situação em que você vê que, naquele momento ali, ele saltou. Você diria que houve um momento do potencial para o realizado. Então, minha obrigação é um pouco isso, um pouco conduzi-los para além. [...] Minha função com eles é incentivar, desafiar, acompanhar nas realizações, nas dificuldades (Docente 6, 56 anos).

O compromisso de desenvolver no aluno uma forma de pensar mais crítica e complexa foi citado por 62,5\% dos docentes (D1, D3, D6, D7 e D8). Eles alegaram que não ficam restritos ao puro pragmatismo esperado pelos alunos, portanto, esforçam-se para que aprendam o significado dos conceitos e as formas de aplicá-los em sua profissão.

O que eu tento desenvolver na turma é o senso crítico. [...] Não é decorar o conceito, mas entender a criação do conceito, porque, se ele entende isso, entende a aplicação, entende a coerência das coisas. Amanhã, muda a ferramenta: ele para de pé porque ele entendeu a raiz. Se ele entendeu a essência, ele aprendeu a criticar (Docente 1, 40 anos).

Eles têm que ter essa visão mais crítica. É uma coisa que eu me cobro bastante. Então, na forma de abordá-los ou nos exercícios que eu passo, eu sempre peço para que eles se posicionem: "eu estou te dando um contexto e quero ver como você se posiciona". Você está desenvolvendo a pessoa para ser líder, para ter visão estratégica, para ter visão de todo, que eu acho que é uma outra preocupação que eu tenho. Também uma visão mais integrada deles como profissionais. É essa a visão de desenvolvimento de competências (Docente 3, 36 anos).

Pelo menos nas minhas disciplinas, o objetivo maior é o aluno de pósgraduação ser conduzido a uma reflexão e a um questionamento maior, a um pensamento crítico para aprofundar um pouco mais aqueles conhecimentos (Docente 6, 56 anos).

Qual é a minha visão do lato sensu? Tenho que aumentar o repertório crítico dos alunos. Não adianta, o docente tem que dominar uma determinada área, tem que ter uma expertise numa determinada área, senão, na segunda pergunta um pouco mais densa e direta, ele não vai saber responder. $\mathrm{E}$ o aluno que questiona e tem o pensamento mais crítico é o que faz o professor avançar (Docente 8, 64 anos). 
Os dois docentes mais experientes (D7, com 29 anos, e D8, com 34 anos) reforçaram a importância da relação com os alunos, valorizando o aspecto humano e o vínculo pelo contato visual (D7) e reconhecendo a empatia e a flexibilidade como características fundamentais do docente do lato sensu (D8).

Bom, eu vou falar de uma questão que é um valor para mim. Eu não consigo pensar no trabalho docente, se não der atenção ao meu discente. Acho que o nosso primeiro papel é dar atenção a esse ser humano que está diante de nós, desejoso de fazer algo diferente. [...] Por isso, a primeira coisa é estabelecer "olho no olho" com esse discente e [...] entrar nessa compreensão antes do conteúdo. Antes da instituição, tem um ser humano ali na frente. E essa dimensão de colocar o ser humano como ele é me dá a responsabilidade de me perguntar também quem sou. [...] Ser melhor no que faço e estar inteiro na atuação. Eu preciso me questionar sempre... (Docente 7, 57 anos).

O mais importante é ter consciência do que está preparando. Ele [o docente] tem que ministrar uma aula que ele gostaria de receber. Imagino sempre a minha filha sentada ali. Os pais confiaram naquela instituição para quê? Para que você faça o melhor possível, dadas as condições que você tem. Isso implica você conseguir despertar o interesse deles a partir dos interesses que eles têm. [...] E, a partir daí, ministrar uma aula que é a que você gostaria de ter. Como você gostaria de aprender, se colocando no lugar deles, discutir aquele tema. Tem que saber administrar, ser flexível, sem ser muito rígido com o aluno (Docente 8, 64 anos).

Mostrando-se reflexivos, coerente com as colocações de Nóvoa (1995), o D2 afirmou que pretende cursar o mestrado para melhorar suas habilidades de ensino, mas, infelizmente, isso pode não acontecer, porque, como vimos, nem sempre a pósgraduação stricto sensu dá prioridade à formação para a docência. O D7 se questiona constantemente sobre sua atuação e procura se desenvolver. E o D8 afirmou que tem consciência de sua responsabilidade como docente e, por isso, procura fazer o melhor possível, independentemente das condições que encontra.

Constata-se que os docentes entrevistados têm identidades profissionais distintas e que estão em permanente construção, independentemente de sua formação, experiência, tempo de docência e dedicação à profissão. Como afirma Silva (2009), a identidade profissional é um processo dinâmico, que resulta de diversas interações ao longo da vida. 


\title{
3.3.2 Formação e desenvolvimento docente
}

Ao analisar os depoimentos sobre a formação pedagógica dos docentes, constatamos que apenas um deles iniciou a profissão com uma preparação prévia: a D6, que cursara o antigo normal e um período da graduação em pedagogia antes de começar o mestrado e lecionar no ensino superior. Entretanto, posteriormente, sentiu a necessidade de estudar docência no ensino superior (pós-graduação lato sensu).

\begin{abstract}
A docência, na verdade, entrou na minha vida bem no início mesmo, porque eu fiz o curso normal. Sou normalista da década de 1970. Quando, concluí o curso normal [...] eu já dava aula no ensino infantil. [...] Prestei vestibular para pedagogia [...] $\mathrm{Na}$ verdade, a especialização em formação para professores do ensino superior [...] apareceu concomitante com o meu mestrado, porque foi uma oferta da própria IES onde eu dava aula, para dar aos professores as ferramentas [...] uma orientação, instruindo os professores a serem docentes. Eu lembro que tinha uma colega professora que falou: "Para que você está fazendo isso? Você já está fazendo mestrado..." [...] Eu tinha que aprender a ensinar (Docente 6, 56 anos).
\end{abstract}

Apesar de 62,5\% dos entrevistados terem a titulação do stricto sensu (adquirida no decurso da carreira docente), só a D6 teve certa uma formação pedagógica anterior ao trabalho docente, mas não dirigida ao ensino superior ou ao lato sensu, corroborando as afirmações de Pimenta e Anastasiou (2011), de que na maioria das IES predominam o despreparo e o desconhecimento científico do que seja o processo de ensino e aprendizagem de adultos.

Comecei com palestra de uma hora, em aulas de colegas. Então, acho que eu falava mais da minha experiência como executivo do que de conteúdo, mas acho que eu sempre tive uma preocupação de fazer a conexão da minha experiência com algum referencial, pra não ficar solto. Eu fui executivo até o final de 2012 e comecei a dar aula (Docente 1, 40 anos).

Não tive nada especifico em relação a isso [formação pedagógica]. É percepção mesmo de mercado, do dia a dia, e de tentar (Docente 2, 32 anos).

$\mathrm{Na}$ faculdade, eu tive mais contato: dei monitoria. Na verdade, a primeira vez que dei aula foi pra minha irmã. Depois, essas outras experiências de aula foram todas informais. Desde quando eu era aluno, tinha aqueles professores muito bons. [...] Mas esses saberes, como cheguei a eles? Não sei (Docente 5, 32 anos).

Foi pela minha história profissional. Eu tinha lá um saber, digamos assim, [...] tinha um conhecimento técnico especializado e de gestão, [...] dominava algumas áreas da minha profissão e estava fazendo o meio do curso de pós-graduação [...], e meus professores me fazem 
um convite para entrar para o mundo da docência (Docente 7, 57 anos).

Ao iniciar na carreira docente, todos os professores entrevistados tinham já uma carreira empresarial (como gestores ou consultores) e formação na respectiva área. Além disso, 50\% (D2, D3, D5 e D6) mencionaram que foram convidados por essa razão, confirmando que os saberes disciplinares e os experienciais têm prioridade perante os pedagógicos para a atuação docente em cursos lato sensu.

Conheço o coordenador do curso há alguns anos, mas de projetos profissionais. Dentro desse trabalho, ele percebeu que eu tinha algum jeito para dar aula, por conta da minha especialização e porque eu sou gestor há alguns anos também (Docente 2, 32 anos).

Inicialmente, eu fui chamada para dar aula na IES por conta da minha experiência no tema do curso. [...] Tinha um projeto grande, num cliente e conheci uma pessoa que era coordenadora da IES. Aí, ela me disse: "Olha, eu sei que você já tem experiência em entrar em sala, em dar palestra para grandes públicos ou para menores, fazer implantação, ensinar o cliente como fazer a implantação, e eu estou com uma dificuldade de encontrar profissionais que saibam falar sobre isso em sala de aula" Eu acho interessante porque sempre gostei desse lado acadêmico. [...] Mas não tive formação pedagógica (Docente 3, 36 anos).

Aí, eu estava com recrutamento e seleção, [...] treinamento técnico e gerencial. [...] Eu estava assim, numa posição boa, confortável, com vinte e tantos anos de empresa, mas muito cansada. [...] Na verdade, conheci algumas pessoas e aí: "Olha, você tem um jeito, você não quer voltar para a sala de aula?" Eu fui. Fui na informalidade. Uma colega minha falou: "Olha, eu vou precisar palestrar em um congresso - vai para mim?" Começou assim (Docente 6, 56 anos).

Os relatos dos D1, D4 e D7 mostram sua preocupação no início da atuação. Os três docentes contaram que conduziram sua primeira aula sem se sentir devidamente preparados.

A minha primeira aula, a minha primeira turma, que peguei cinco encontros [...] estava muito nervoso e eu acho que eu tentei colocar uma melancia dentro de uma lancheira, porque eu preparei, acho, 10 horas de aula e dei em três horas. Acho que os alunos saíram massacrados, mas era o referencial que eu tinha: dar uma aula expositiva. [...] Os executivos são convidados para dar aula, mas não são preparados para isso. Ele sabe falar sobre o que fez e deu certo, [sobre] a experiência dele. [...] executivo não dá aula, executivo trabalha. É diferente. Executivo é pago para tomar decisão. Ele não sabe dar aula, ele sabe falar do que ele fez e deu certo (Docente 1, 40 anos).

A primeira vez em que eu pisei numa sala de aula, que tinha 105 pessoas, foi um choque. Era uma multidão. Eu dava treinamento na 
empresa. Eles tinham como se fosse uma educação continuada. Nós passávamos por treinamento quase o tempo todo. [...] Cada um de nós, gerentes, era responsável pelas formações. Aplicávamos os treinamentos, mas também cada um de nós era responsável por treinar e desenvolver mais uma pessoa para que essa pessoa desse um treinamento (Docente 4, 42 anos).

Então, dentro do lato sensu, o primeiro desafio foi assim, "ok, eu vou entrar na sala de aula; tenho lá 80 alunos na minha frente, não é? $E$ aí eu vou contar as minhas histórias, e eles vão ficar felizes." Eu pensei "joia". E foi isso mesmo que aconteceu, de fato: "nossa, professor, que maravilha, que legal etc." E aí a gente se encanta. Agora, quando a gente chega lá, na hora de avaliar, na hora de mensurar o conhecimento aprendido, na hora de perguntar "essa foi a melhor maneira de falar sobre isso?", quer dizer, quando a gente começa a entrar no papel e no trabalho da educação do ensino superior, a gente começa a se defrontar com coisas para as quais a gente não foi preparado. [...] Eu sei, tenho esta facilidade, esse conforto natural para lidar com grupos, me orientar em sala e falar com grupos. Mas eu deparei a dificuldade no sentido da docência propriamente dita. Aí, já me obrigou a uma outra dimensão de desafios: recuperar conhecimentos que estavam esquecidos na minha própria formação e alcançar outros com os quais eu não tinha tido contato ainda (Docente 7, 57 anos).

Como constatou Gonçalves (2013), o docente do lato sensu procura formação pedagógica depois de começar a lecionar e, na maior parte dos casos, por iniciativa própria. E foi exatamente o que ocorreu com alguns dos docentes. O D1 procurou suprir essa carência participando da criação de um laboratório sobre didática na IES onde fazia mestrado - pois não havia disciplinas específicas - e o D7, cursando disciplinas sobre didática e educação no stricto sensu, mesmo não sendo obrigatórias. Mas, mesmo assim, para o D7, talvez não exista uma formação ideal.

Tem uma iniciativa que era menos estruturada, mas me ajudou bastante, que foi [...] quando eu estava pensando em dar aula... Até então, na IES em que estudava, não tinha aula de didática. [...] eu conversava com os outros mestrandos, todo mundo meio desolado, "como a gente vai fazer?" Então, a gente formou um grupo [...] que era um laboratório de boas aulas. A gente se encontrava [...] para discutir o que a gente estava fazendo, o que a gente estava vendo em sala de aula que dava certo para compartilhar com os amigos. Isso ajudou bastante (Docente 1, 40 anos).

Objetivamente, sim, eu tive aulas de didática de ensino superior etc. Estudei educação, foi um dos créditos que eu quis fazer, não só no mestrado, mas no doutorado também. Então, tentei buscar exatamente no campo da educação. [...] A gente faz um trabalho de gerar possibilidades no mundo do conhecimento para o qual nunca fomos preparados. $E$ acho que também não tem preparação pronta (Docente 7, 57 anos). 
Outro aspecto relevante é que $75 \%$ dos docentes tinham experiência em conduzir treinamentos corporativos antes de dar aula (D2, D3, D4, D5, D6 e D7). Talvez se pudesse investigar o quanto essa habilidade corporativa concorre para a atuação docente, pois $62,5 \%$ dos entrevistados relataram que a principal referência para começar a lecionar foi essa experiência anterior. Apenas o D7 não quis fazer essa relação direta, afirmando que, no seu caso, os fatores que o ajudaram eram já pertencentes às características pessoais. Isso pode ser questionado à luz das contribuições de Silva (2009), para quem a identidade profissional se constrói por meio de sucessivas interações entre o indivíduo e seu meio sociocultural por toda a sua trajetória.

Acredito que ele [o coordenador do curso que o convidou a lecionar] tenha visto essa habilidade nos treinamentos (Docente 2, 32 anos).

Foi pelas experiências que eu tive já desde cedo, quando eu comecei a dar treinamento (Docente 3, 36 anos).

$\mathrm{Na}$ verdade, como consultor, você acaba dando palestra [...] para o público em geral. Então, [...] você acaba criando aquela experiência, mesmo (Docente 5, 32 anos).

Sim, a minha história, desde o início, se assemelha muito à sua, nesse sentido. Eu nasci profissionalmente na área de treinamento. [...] Sua pergunta é complexa, eu não faria uma associação assim tão imediata entre essa mesma competência requerida para treinamento e para um ensino superior. São duas coisas distintas. Você se julga mais confortável na oratória, por isso você vai ser um bom professor? [...] Não dá para fazer uma associação direta. Não, não faria isso, porque lá o desafio é de uma outra ordem (Docente 7, 57 anos).

Como o D1 e o D8, o D5 também mencionou como referência para a sua atuação docente professores que os inspiram. O D1 falou especificamente de um professor de mestrado que marcou suas lembranças. Essas declarações confirmam o que diz Tardif (2002), que o professor se baseia nas tradições escolares e em sua própria experiência como aluno para alcançar seus objetivos pedagógicos.

A minha referência [...] é um professor no mestrado que foi excelente. Ele usava muito bem diferentes estratégias, e comecei a me inspirar nele. Era uma estrutura de aula que misturava uma expositiva dialogada com discussão [em plenária] [...] e depois ele fazia um seminário grande, cada turma apresentava. Eu falei "meu, que coisa legal, que aula dinâmica. Eu preciso fazer alguma coisa assim" (Docente 1, 40 anos).

Eu tive professores que faziam isso [prática pedagógica], mas não tive uma disciplina especifica. Nunca tive metodologia, [mas] tive uns caras bacanas. Você estudar numa escola bacana, de primeira linha, a grande vantagem é essa, que cada professor é uma inspiração. Daí, 
procurei fazer isso. Você ministra a aula do jeito que gostaria de receber. E como eu gostava de receber? Dos professores que eu tinha na graduação que eram uns caras muito bons. Então, a própria atitude deles não era falar de pedagogia, eles praticavam pedagogia (Docente 8, 64 anos).

Sempre brincava com eles [alunos] com um quiz ${ }^{14}$ antes da aula, com perguntas de curiosidade, que foi uma estratégia que um professor de inovação aplicou comigo uma vez, e achei muito legal. Eu tive alguns bons professores, mesmo. Então, você aprende um pouquinho como esses caras conseguem dar uma boa aula (Docente 5, 32 anos).

Todos os entrevistados fizeram reflexões interessantes sobre os saberes pedagógicos. O D1 revelou que está sempre aprendendo para não se restringir a ensinar apenas expondo informações, conforme fez em sua primeira experiência como docente. Em função disso, considerou como dois grandes marcos de mudança em sua atuação docente a formação em aprendizagem baseada em problemas (problem based learning - PBL), quando conheceu as metodologias ativas de aprendizagem, e a disciplina sobre didática que cursou no doutorado.

Formalmente, ouvi falar de metodologias ativas na academia dos professores com práticas pedagógicas da outra IES [onde é CLT]. Estão com esse projeto muito forte. E, quando eu vi o negócio, falei "é disso que eu preciso". Parece que estava vestindo uma blusa que não era minha, fazendo um negócio que me não cabia direito. De repente, eu ouvi e "poxa, é essa proposta que eu quero fazer". E aí eu avancei. [...] Na pós, eu virei a referência de PBL. Eu fiz há um ano o treino de PBL. Me apaixonei tanto pelo método, estudei tanto, que hoje sou um multiplicador. No começo deste semestre [...] entrei no doutorado e fiz a disciplina de didática aplicada à administração. Foi um outro divisor de águas. Também várias coisas que eu fazia meio "de orelhada" começaram a ganhar mais sentido (Docente 1, 40 anos).

Sobre a formação pedagógica, houve algumas percepções e posturas críticas. O D8, que relacionou como uma ciência destinada para crianças, questionou a falta da prática nos cursos de pedagogia, que não preparam de fato o docente, e o D4 admitiu que nunca participou das semanas de capacitação docente, promovidas pela outra IES, mesmo sendo contratado pela CLT.

Na IES pública onde trabalhei, tem o curso de pedagogia, mas eles ficam discutindo Piaget, e o que a gente precisa é de um cara que entre na sala de aula e encante as crianças, que as crianças fiquem doidas pra aprender. E os caras ficam discutindo o que é importante, mas a gente deveria formar na pedagogia de forma mais prática, e não sou só eu que estou falando isso. O Cristovam Buarque, por exemplo,

\footnotetext{
${ }^{14}$ Quiz é um conjunto de perguntas cujo objetivo é avaliar conhecimentos sobre determinado assunto.
} 
senador da república, disse que é assim que tem de ser. [...] não ficar só discutindo Paulo Freire - você tem de discutir esses caras -, mas tem de aplicar isso no mundo concreto, real, com as crianças. Temos muita evasão na escola, e o professor não sabe ensinar (Docente 8, 64 anos).

Aqui (na outra IES que é docente pela CLT), aparece um curso [...] que todo semestre tem alguma coisa a respeito de práticas pedagógicas. Estou devendo todos, nunca fiz, desde que entrei. Eles chamam de semana de capacitação docente. São quatro ou cinco cursos, normalmente 10 dias antes do começo das aulas, de que você pode escolher alguns módulos gratuitos e fazer (Docente 4, 42 anos).

Para a D6, um ponto crítico relevante é o alto custo do ensino privado, que a levou a interromper o curso de pedagogia. Já o D7 criticou a falta de incentivo à formação para a docência no stricto sensu, questão também levantada pelo D1. Essas críticas convergem com a afirmação de Chamlian (2006), de que a ênfase dos cursos de pós-graduação no Brasil sempre se centrou na formação de pesquisadores.

Prestei vestibular para pedagogia, só que minha mãe não tinha condições de bancar o curso; não consegui prestar em públicas [IES]. É um curso caro. Aliás, os cursos são caros na educação privada, é tudo diferente. Eu fiz o primeiro semestre, mas tive que mudar de curso para ganhar mais, porque, com o que eu ganhava, não podia me manter. Aí, pedi transferência para administração [...] e aproveitei as disciplinas básicas [...]. Em três meses, eu consegui um novo trabalho e consegui pagar minha faculdade (Docente 6, 56 anos).

A natureza do mestrado e doutorado é voltada para a pesquisa, para o pensamento crítico e para o trabalho intelectual muito isolado. Mas depois existe a cobrança de que ele [docente] seja democrático e participativo em sala de aula, o que gera uma incoerência. Isso traz dificuldades, a alguns professores que ficam presos a essas "amarras" aprendidas. [...] Não tem tanto incentivo, não é tão estimulada a questão da docência quanto a da pesquisa. Depois, ficamos sedentos por tecnologias sociais $e$ instrumentos que nos possibilitem horizontalizar o conhecimento em sala de aula, como a sala de aula invertida, ou tornar a aula menos penosa para o professor e o aluno (Docente 7, 57 anos).

Tem mesmo alguma coisa errada no nosso sistema. Formamos pesquisadores que dão aula. Na formação do mestrado e do doutorado, o que é mais estimulado é o saber técnico (Docente 1, 40 anos).

A fragilidade da qualificação pedagógica desses docentes condiz com a constatação de Pimenta e Anastasiou (2011, p. 23):

A formação de docentes para o ensino superior no Brasil não está regulamentada sob a forma de um curso específico, como em outros níveis. De modo geral, a LDB admite que esse docente seja preparado 
nos cursos de pós-graduação tanto stricto como lato sensu, não se configurando estes como obrigatórios.

A análise do conjunto de respostas confirma a não obrigatoriedade da formação pedagógica para a docência nos cursos lato sensu e a hipótese de que muitos docentes são profissionais especialistas em sua área de conhecimento, mas não têm a necessária formação para conduzir processos de ensino e aprendizagem, coerente com as constatações de Soares (2009), baseadas em evidências de seus estudos. Ficou explícita a falta de acesso, incentivo e sensibilização à formação pedagógica, seja por parte dos docentes, seja por parte do nosso sistema educacional.

\subsubsection{Saberes pedagógicos e prática docente}

Os depoimentos dos entrevistados revelaram, primeiramente, a falta de clareza sobre o que seriam os saberes pedagógicos de docentes do lato sensu. Na maior parte dos casos, foi necessária uma explicação sobre o tema, especialmente na pergunta sobre a composição desses saberes.

Dois exemplos ilustraram bem essa situação. Para o D8, conforme citado, a pedagogia é mais relacionada ao ensino infantil, e sua referência sobre o tema foi construída a partir do compartilhamento de experiências com colegas da mesma área e de sua própria prática docente. Apesar de ser o entrevistado com mais tempo de docência desenvolvida principalmente em universidade pública (34 anos), afirma que nunca participou de ações pedagógicas formativas, nem mesmo no mestrado ou no doutorado. Portanto, os seus saberes pedagógicos foram desenvolvidos durante a prática docente.

Isso vem com a experiência na sala de aula, a convivência, você conversando com seus colegas de pedagogia (Docente 8, 64 anos).

E o D1 referiu-se ao saber pedagógico como didática, pois o compreende como saber transmitir o conteúdo e fazer-se entender pelo aluno. Essa é uma visão restrita à dimensão do ensino, uma vez que a pedagogia universitária consiste em uma abordagem mais ampla da educação sobre os conhecimentos que fundamentam a prática educacional, concebidos pelos saberes pedagógicos docentes (Almeida, 2012). 
Então, acho que tem um saber que é o saber técnico, tem um saber que é o saber pedagógico, não sei se é mais pedagógico ou didático, mas vamos falar que é didático: eu sei como me fazer entender, sei como transmitir esse conteúdo (Docente 1, 40 anos).

Apenas dois docentes mencionaram de maneira sucinta conceitos educacionais relativos à prática do docente do lato sensu, um número baixo que demonstra a carência dos saberes pedagógicos. A D3 comentou a importância da andragogia (aprendizagem de adultos) para o processo construtivo da aula. E o D1 citou o ciclo de aprendizagem de $\mathrm{Kolb}^{15}$ sobre o entendimento dos estilos de aprendizagem dos alunos, além de Paulo Freire e Malcolm Knowles. Segundo ele, foram conhecimentos aprendidos recentemente, na formação pedagógica da outra IES (não a selecionada para esta pesquisa), onde é contratado pela CLT, e na disciplina de didática que escolheu cursar no doutorado. Ambas as iniciativas revelam seu interesse em desenvolver seus saberes pedagógicos.

Uma coisa que eu sempre olho, e isso sempre me preocupa, é saber se está todo mundo acompanhando e participando igualmente. Se o curso está sendo bom para todo mundo. Dar abertura para eles construírem junto comigo, que eu acho que é uma coisa de andragogia, que a gente tem que se preocupar com a construção do conhecimento, com o aprendiz adulto. $\mathrm{E}$ aí um pouco do código de conduta de como vão funcionar as nossas interações e eu, no papel de professora, o que posso e o que não posso. Às vezes, até em TCC eu percebo isso, o grupo chega feliz da vida, e você tem que dar uma notícia que não é tão boa assim. Então, eu procuro ouvir primeiro... "O que vocês acharam dessa parte que vocês construíram? Me contem como foi" (Docente 3, 36 anos).

Eu tive contato com Paulo Freire, acho "animal". Achei o [Knowles], ${ }^{16}$ da andragogia, obsoleto. Poxa, cada dia aprendo uma coisa nova. Então, falta muita coisa para eu aprender ainda [...] mas estou sempre aprendendo coisas novas. Acho que um dos desafios - aula expositiva é fácil - é conseguir casar a profundidade de conteúdo com o entendimento. Conseguir adequar pensando em Kolb, quando vou para o mais crítico, quando vou para o reflexivo, quando vou para o ativo, quando vou para o teórico... Como uso a ferramenta certa para o que eu preciso construir naquele momento? $\mathrm{E}$ isso, às vezes, eu sinto que... Acho que me falta experiência como docente. Me falta experiência. Fui apresentado ao Kolb há dois meses, e agora é que comecei a pensar. Em algumas disciplinas, estou usando projetos PBL, estudos de caso, expositivas dialogadas, estou combinando tudo, porque cada uma precisa explorar uma coisa. Acho que um dos meus desafios é esse. Como eu desenvolvo uma "caixa de ferramentas", aprendo a sacar de acordo com o meu objetivo. E aí

\footnotetext{
${ }^{15}$ Referência ao Ciclo de Aprendizagem de Kolb (KOLB, D. A. Experimental learning: experience as the source of learning and development. New Jersey: Prentice-Hall, Englewood Cliffs, 1984).

${ }^{16}$ Referência às propostas da andragogia (Knowles, 1980).
} 
passa por um nível de profundidade muito maior no meu planejamento de aula. Preciso revisar o programa, revisar a aula para usar a estratégia certa para cumprir o objetivo (Docente 1, 40 anos).

Sobre a participação em ações de formação, o D1 reconheceu a importância do trabalho do núcleo de práticas pedagógicas da outra IES em que trabalha, onde pesquisa a atuação docente e conduz a formação pedagógica (conhecida como academia de professores) para mudar o processo de ensino e aprendizagem: deslocar o foco dos docentes para a formação de um aluno com senso crítico, e não apenas na transmissão de conhecimento. Percebemos que a criação e a atuação de núcleos de desenvolvimento pedagógico docente, como este citado, está crescendo nas IES de São Paulo, porém ainda precisam se consolidar para alcançar um número maior de docentes do lato sensu de maneira continuada.

Eles têm um núcleo de práticas pedagógicas [...] com um time que
trabalha muito pesquisando o que os professores fazem. Por volta de
uns três anos atrás, a IES fez uma revisão do plano pedagógico que
fala em formar um aluno capaz de transformação, não um aluno
conteudista. Para conseguir desenvolver esse aluno, faltava a gente
desenvolver senso crítico nele. Para desenvolver senso crítico,
precisa de um professor. Então, ao invés de trocar todos os
professores, eles começaram a desenvolver os professores. Mas teve
uma grande resistência. [...] Aí, você vê muito professor que - e não é
só professor velho; todo mundo fala "professor velho", mas não é, é
professor que tem pensamento antigo. Tem muito professor que acha
que a metodologia expositiva empodera o professor porque é o dono
da verdade, porque é mais seguro, você sabe tudo o que vai ser
discutido porque é você quem comanda. Para você dar voz ao aluno,
você não sabe o que vem. E [...] para trabalhar com metodologia ativa,
você tem que trabalhar com a visão de professor falível, que, para a
gente, para alguns professores e alunos, é inaceitável. [...] Então, acho
que tem essa mudança de paradigma (Docente 1,40 anos).

A D3 é contratada pela CLT na IES estudada, que oferece ações educacionais aos professores. Mas não são obrigatórias e ocorrem geralmente em horários em que ela não está na instituição, razões pelas quais ela só participa eventualmente. Portanto, entendemos que, mesmo quando a IES faculta formação a seus docentes, não necessariamente todos os contratados CLT conseguem participar. Para tanto, deveria ser obrigatória e dentro do horário de trabalho do docente. Assim como relatou o D7, a D3 arrolou como forma de desenvolvimento o compartilhamento de ideias com outros professores e com o coordenador do curso, que acontece pontual e informalmente. 
Acho que tem muita coisa disponível, eu uso poucas, por conta do trabalho de consultoria. Acabo vindo à IES muito mais só para as aulas, especificamente. Então eu acho que no meu caso acontece mais pela troca com os coordenadores e com os outros professores (na própria sala de professores). Eu acho que essas trocas elas são importantes, mas tem muita ação na IES, eles fazem muitos eventos. Outro dia tinha um grupo de professores fazendo um curso de mediação cognitiva, então tem bastante ferramenta. Não é obrigatório, mas está disponível (Docente 3, 36 anos).

Como visto no relato do D1 e da D3, os docentes reconhecem a necessidade de se desenvolverem saberes pedagógicos, mas acreditam que, no caso dos docentes do lato sensu, é o tempo de experiência na própria docência que pode concorrer para essa evolução.

Então, a parte técnica é fácil, mas, nessa outra parte aí [pedagógica], eu precisava de mais bagagem também para fazer bem feito: como é que a gente vai apresentar o plano, como é que a gente vai fazer com que eles conheçam os temas, comecem a utilizar isso no dia a dia, trazê-los para as próximas experiências que forem necessárias (Docente 3, 36 anos).

A aprendizagem autodirecionada é outro meio de desenvolvimento citado. $O$ D2 e o D7 afirmaram que participam de eventos ou grupos que renovam seu conhecimento, a partir de suas próprias iniciativas. O Para o D2, envolver-se em encontros de seu campo de atuação contribui tanto para sua preparação como docente como para o trabalho empresarial, e ele ainda procura ler livros sobre outras áreas para expandir seu conhecimento. Já o D7 participa de eventos de sua área e de grupos que geram aprendizagem a partir de experiências inovadoras com novas metodologias, não exclusivamente da área da educação.

Eu participo de alguns workshops, de alguns eventos da [minha] área especifica, não só por conta da academia, mas por conta do meu trabalho. Tem até a música do Milton Nascimento, "o artista vai aonde o povo está". Você precisa ir aonde seus colegas estão, aonde você pode trocar conhecimento, figurinha, experiências. Esse é um outro ponto de partida na minha preparação. Para a especialização, obviamente você precisa ter uma literatura. Em casa, eu tenho em torno de 300 livros, tenho uma minibiblioteca. Entendo que, apesar de a minha formação, eu preciso também ler algumas coisas que fogem ao meu cotidiano. Então, eu leio Jorge Amado, leio João Ubaldo Ribeiro, que são autores brasileiros, leio literatura estrangeira. Muito mais do que falar sobre a questão especifica, sua questão profissional, é entender também como funciona a questão social, ler outras coisas em relação ao saber, mesmo, outros assuntos que ampliem seu 
repertório. Esse, para mim, é o principal ponto de vista. Esse é um ponto primordial para mim (Docente 2, 32 anos).

Foco na atualização, quer dizer, eu faço um esforço. A palavra esforço aqui não sentido duro, pesado, mas no sentido de esforço cotidiano. Então, uma das minhas frentes de trabalho é a minha própria atualização, e aí, entre elas, atualizar-me na literatura do pensamento e na minha área de concentração, mas também atualizar-me no meu mundo das atividades dos cursos lato sensu, que são as áreas que eu ministro. Tenho lido um pouco, mas tenho vivido não só pela área em que eu trabalho, [...] eu sempre acabo participando de situações de sala, de grupos inovadores, de situações inovadoras como metodologias. Essas experiências inovadoras, nada veio do mestrado, nem do doutorado (Docente 7, 57 anos).

\section{O D7 compartilhou um exemplo de uma ação o qual participou de uma}

atividade, que posteriormente aplicou em aula no lato sensu e que reconhece como metodologia de aprendizagem.

Perfeito. Então, eu estou participando de uma atividade de planejamento estratégico com 120 pessoas, e o facilitador estabelece uma rotina de trabalho. Nós estamos em 10 mesas, mais ou menos, [...] com seis pessoas em cada uma. E tem quatro horas para trabalhar com 120 pessoas - consegue chegar a bom termo. Ele usa uma ferramenta que a gente faz em sala de aula, quando a gente quer aprofundar um determinado tema, e que tem o nome em inglês, chama-se open space ou então world café. [...] O que eu fiz recentemente foi aplicar. [...] Em aula, pedi a eles [alunos] uma reflexão, deixei eles entregarem no dia, e fomos debater. Eles estavam imaginando que a gente ia fazer um grande círculo e todo mundo ia debater. Eu falei: "Não, vamos lá, vamos fazer diferente! Vamos dividir em grupos e trazer essa questão para o centro do grupo". Então, estão lá sete grupos de seis pessoas cada um: "elejam agora um guardião. Quem será, do grupo de vocês, o guardião?" O guardião é a pessoa que vai sistematizar isso, que fica fixo nas rodadas. E aí "o que nós vamos fazer? Vocês vão discutir cinco minutos qual é esse papel, eu vou dar um sinal. Quando eu der um sinal, o guardião fica, e os demais rodam para outros grupos, e aí vamos fazendo". Ou seja, aquele mesmo tema, todo mundo trabalhou [...], todo mundo compartilhou e teve um aprofundamento, porque, quando o guardião chega, ninguém vai repetir o que já foi falado, e ele vai agregar. Quando a gente tem necessidade de refinar determinado tema, a gente se utiliza então do world café como metodologia. Funciona. Foi criado para grandes grupos, mas, em pequenos grupos, também dá certo. Onde que eu vi isso? Quando estava participando de grupos inovadores, grupos alternativos que estavam discutindo outras coisas, nada de pedagogia, nada de educação, nada, mas sobrou isso. Nossa, o que é isso? Eu chamaria aqui de metodologia. [...] Assim tem sido com tantas outras coisas, e tem sido muito rico (Docente 7, 57 anos).

Identificamos que a maior parte das contribuições dos entrevistados sobre saberes pedagógicos foi relativa à prática docente: preparação da disciplina, 
estratégias e metodologias de aprendizagem, relações interpessoais e processo avaliativo.

O ponto de partida citado por 50\% dos docentes (D4, D5, D6 e D7) foi conhecer previamente o perfil dos alunos para entender suas necessidades e orientar as disciplinas, preocupação que está diretamente ligada à andragogia, que é a educação de adultos (Knowles, 1980). Alguns docentes obtêm essa informação do coordenador do curso (D5 e D8), também para entender melhor a estrutura curricular e as expectativas do próprio coordenador. Para garantir a interdisciplinaridade e complementar seu planejamento, o D5 procura os outros docentes do curso, despendendo para isso seu próprio tempo, já que é um docente contratado temporariamente (carta-convite). Essa iniciativa deveria ser organizada pela IES para todos os cursos lato sensu, não só por sua evidente importância pedagógica, mas também por ter gerado o retorno positivo dos alunos.

Costumo sempre personalizar a aula e a grade do curso com as orientações do coordenador. Primeiro, tenho uma conversa ele para entender o curso, o perfil da turma, que qualificações e disciplinas havia ao longo desse curso. Com base na conversa com 0 coordenador e com outros professores, estudo a ementa e a bibliografia, faço pesquisas. Li os trabalhos dos módulos que os alunos já tinham feito. Daí, tento traçar uma ideia, qual vai ser meu começo, meio e fim. Uma das coisas com que me preocupei bastante foi ver o que os alunos já aprenderam, pra não ficar repetindo conceitos. E, pelo feedback da turma, foi positivo, porque eu trouxe coisas novas (Docente 5, 32 anos).

Na primeira aula, eu não consigo dizer: "Vai fazer exatamente isso daqui". Não dá, porque tem que minimamente reconhecer a sala, definir que nível de profundidade eu vou dar às leituras, que tipo de leitura. [...] Mas, enfim, conhecer a sala, definir que tipo, que estratégia vou usar para avaliação. Eu não costumo, até por essas razões, repetir o conteúdo, os itens que eu usei. Não gosto. Por isso, não consigo me imaginar com três ou quatro turmas: eu não conseguiria fazer isso (Docente 6, 56 anos).

Então, tem uma primeira dimensão que é isso, e eu pergunto se aquele plano de ensino, se as perguntas são as mesmas. Sempre peço à gestão que me dê o perfil da turma; às vezes é possível, às vezes não. Às vezes, eu pego esse perfil da turma e transformo em algo mais "palatável" para passar para os meus professores. Monto os gráficos mostrando quem são as pessoas com as quais eles vão falar... Quando isso é possível, é legal, porque o pessoal já recebe antes a informação (Docente 7, 57 anos).

Mas, [...] não quero ir lá e ficar falando o que tem que ser. Então, eu trabalho alinhado com o que é esperado pelo coordenador (Docente 8, 64 anos). 
A D3, o D4, o D5, a D6, o D7 e o D8 (75\%) relataram que preparam sua disciplina a partir do plano pedagógico do curso ou do plano de aula da própria disciplina. Os elementos considerados - ementa, objetivo, bibliografia, recursos de apoio e avaliação - permitem contextualizá-la e fundamentá-la, além de dar uma visão interdisciplinar que evita sobreposição de conteúdos e imprimir-lhe um desenvolvimento personalizado. Por sua vez, a D6 estrutura suas aulas com início, desenvolvimento e conclusão, a partir de um objetivo claro e articulando estratégias e recursos de aprendizagem. Os docentes não se aprofundaram na conceituação ou no modo de alcançar os objetivos de aprendizagem e a sua complexidade, como prevê, por exemplo, a taxonomia de Bloom et al. (1956), que define diferentes níveis de aprendizagem.

Em geral, são umas sete aulas por disciplina. Para mim, tudo começa no projeto pedagógico do próprio curso, [...] o que é aquela disciplina, sua descrição [...] qual é o objetivo dela, onde ela pretende chegar e qual é a bibliografia. Então, parto dessa bibliografia para fazer a contextualização e o embasamento teórico. E o próprio projeto pedagógico me dá o objetivo da aprendizagem, se eles querem só conhecer aquele conteúdo, se eles vão usar para uma situação específica, se eles vão usar para um plano de intervenção (Docente 3,36 anos).

Umas três ou quatro vezes, disseram "o professor falou isso, o outro professor falou isso". Não atrapalhou a aula, mas aquilo me incomodou. Poxa, estou falando coisa que o outro está falando também. O aluno está pagando pra ver duas vezes a mesma coisa? Eu tive e tenho essa preocupação. Acho que tudo isso compõe o planejamento (Docente 4, 42 anos).

Eu tenho como papel cumprir aquilo que foi determinado no plano de ensino, nos planos de aula, mas também é minha função discutir as coisas que estão lá dentro, propor melhorias, atualizar bibliografia e metodologias. [...] Eu procuro sempre ter uma lógica na preparação da aula, que é [...] uma introdução, um desenvolvimento e uma conclusão ou um fechamento, digamos assim. Sempre procuro estruturar dessa forma, encaixes, recursos e as estratégias, nessa sequência, e deixo claro para eles que os objetivos de aulas são esses, e sempre que possível eu tento amarrar. [...] Às vezes, não há o tempo de fechar, mas normalmente [pergunto] "foi concluído? Isso aqui a gente atingiu ou não? Olha, ficou alguma coisa pendente? Então, isso aqui continua na próxima aula". Eu tenho essa preocupação de estruturar, sim, até porque isso me permite organizar meu trabalho prévio, e eu dou a eles o caminho (Docente 6, 56 anos).

Os docentes são alinhados a partir do projeto pedagógico e ementas, mas eles têm liberdade no exercício da atividade (Docente 7, 57 anos).

Partir do programa é saber exatamente o que você vai fazer. Vou ter oito encontros. O que vou fazer no primeiro, no segundo... O que eu faço? Faço um programa de ensino e a preparação por aula. O que vai ter em cada aula? $1^{a}$ aula: qual é o material? [...] Considerando a 
ementa, os temas, objetivos, metodologia, depois bibliografia básica e bibliografia complementar (Docente 8, 64 anos).

A D3 relatou detalhadamente como determina a partir do plano pedagógico a estratégia educacional, articula as variadas metodologias de aprendizagem e o processo de avaliação. O mais interessante de suas afirmações é a preocupação em realizar uma atividade que será posteriormente trabalhada no TCC, o que demonstra a sua visão de interdisciplinaridade do curso.

A partir daí [do plano pedagógico], eu começo a trabalhar o conteúdo, o embasamento teórico, a fundamentação e aí sim eu parto para as situações de aprendizagem, que é o que eu vou dar. Aqui, eu dou um vídeo, aqui eu vou passar a teoria, aqui eu vou explicar o vídeo, eu vou dar um exemplo, a gente vai trabalhar um determinado questionário, e vou programando de acordo com o que a turma sabe desenvolver. Em geral, eu gosto de trabalhar com diagnóstico, porque é algo que eles vão trabalhar no TCC também. Peço para eles trabalharem [...] com uma resenha crítica, de que eu também consigo ver o outro lado: o quanto eles estão entendendo da matéria, o quanto eles sabem argumentar a partir daquilo que leram [...], se estão entendendo, se estão indo pelo caminho certo. Sempre tem pelo menos um trabalho individual e um trabalho em grupo. Quando há oportunidade, eu uso uma terceira ferramenta [...]. Aí depende muito da disciplina, mas eu dou um estudo de caso, com um exercício que faça com que eles se posicionem no papel de um gestor e como eles vão trabalhar aquela situação específica, e nisso eu vou aumentando a complexidade também. [...] Quando é possível dar três atividades, eu dou duas individuais e uma em grupo [...] Acho que um pouco dessa construção é aquilo que vem dando certo. Porque eu acho que deu certo de encontrar ferramentas para a avaliação do aluno, que são também ferramentas que o aluno gosta de fazer (Docente 3, 36 anos).

Quanto ao conteúdo da disciplina, 50\% dos docentes (D2, D3, D4 e D7) afirmam que o verificam e atualizam previamente e no decorrer das aulas, incluindo relevantes acontecimentos do mercado. Para o D4, mesmo com o planejamento do conteúdo e materiais, prefere montar a aula no próprio dia para ser mais assertivo.

O cuidado de preparar esse material toma um período razoável do meu tempo. Obviamente, você atualiza. O mercado é dinâmico. A gente tenta trazer sempre o que o mercado apresenta para os conceitos acadêmicos. Eu mesmo tenho o hábito de já ir colecionando notícias que trazem para o contexto acadêmico [...] Então, basicamente, a preparação é essa (Docente 2, 32 anos).

Em geral, faço a aula no dia. Eu faço o planejamento e tenho o material que eu separo para cada uma das aulas, mas a aula, a organização dos slides, é no dia. Para não perder nada. Porque às vezes acontece uma coisa muito legal que eu poderia introduzir, mas não vou mexer 
numa aula que está pronta e tal. Então, de certa forma, ela nunca está pronta (Docente 4, 42 anos).

Checo se meus conteúdos estão atuais e se eles [...] ainda correspondem à realidade. Checo fontes, faço uma verificação, faço uma pesquisa de fontes, atualizo se eu estou utilizando documentação ou conteúdo que já são sabidos. Portanto, se eu estou multiplicando, estou novamente transmitindo, estou checando a cada instante. Eu uso muito aspectos digitais quando estou falando da importância de determinada organização na sociedade: trago o site dela. Estou olhando [...] se está correto, se o link que estou colocando especificamente no mundo digital existe de fato, se não estou dando uma informação incorreta (Docente 7, 57 anos).

O D8 entrega o planejamento impresso aos alunos na primeira aula, atitude com a qual ele demonstra respeito por eles e conquista sua confiança desde o início. Também o D7 tem essa mesma preocupação e começa a disciplina propondo à turma uma reflexão inicial para alinhar suas expectativas e discutir conjuntamente o significado do curso, indo além do conteúdo. Notamos que ambos concorrem para conscientizar os alunos da estrutura e da importância da disciplina, construindo desde o início uma relação humana com eles.

Aí, o aluno está folheando isso aqui [material impresso de apoio]. Eu já entrei na sala de aula e distribuí um para cada um: "vamos acompanhar a leitura". [...] Porque aí, inclusive, você dá confiança. Eles pensam assim "o professor está fazendo a parte dele, então..." Desse ponto de vista, é também respeitar os alunos. Eu acho que isso é uma outra coisa importante: você respeitar aqueles caras que vieram ali (Docente 8, 64 anos).

Quando abro meus trabalhos, no começo do curso, frequentemente eu reflito com eles: quando começou a decisão deles de sentarem nessa cadeira? Quer dizer, por que eles estão ali? Há um investimento financeiro evidente, mas "há um investimento de tempo que vocês estão dando", eu costumo dizer. "Quando vocês viram as informações relativas ao curso dessa instituição, em alguma medida, aquilo você julgou que atendia. Criou alguma expectativa. Então, veja, olha só, como nós aqui, olhando para os conteúdos, podemos atender as expectativas humanas de vocês?" Isso me coloca uma dimensão que vai além dos conteúdos (Docente 7, 57 anos).

Como as disciplinas têm, em média, de seis a oito aulas, uma das formas de otimizá-las é pedir leituras prévias. A D3, o D5, a D6 e o D8 disseram que adotam esse recurso, mas cada qual tem uma opinião diferente a respeito. A D3 comentou que tem dificuldade de convencer os alunos a lerem antes das aulas, o que compromete o planejamento e a condução do conteúdo. Para o D5, o aluno deve ter autonomia nessa decisão, por isso, não cria formas de controlar a leitura, e às vezes 
sugere bibliografia complementar. Já a D6 e o D8 citaram maneiras que criaram para garantir que os alunos façam essas leituras.

Eu já tentei de várias formas, "vamos ler, e a gente vai sentar e discutir o texto". Não adianta. [...] Sempre tinha que fazer uma pequena abordagem do texto, porque eu sempre percebia que ninguém lia. Mas aí ocupa muito tempo e acaba caindo na mesma da exposição. Então, uso a plataforma virtual da IES para disponibilizar as aulas, os conteúdos, para passar avisos para os alunos, para deixar lá registrado, para lembrá-los ou prepará-los para a aula seguinte (Docente 3, 36 anos).

Sempre fecho a aula perguntando o que acham do dia e o que querem ver. Dou um teaser ${ }^{17}$ de como vai ser a aula seguinte, de como gostariam mais da abordagem. [...] Procuro, em todo slide meu (80\% deles), trazer a fonte, compartilhar estudos com as referências. "Quer ler pra se preparar pra aula, fique à vontade. Não quer ler (porque também é um direito), tudo bem. Vou dar um breve panorama sobre o assunto". Mas eu acho que é importante para o docente abrir, trazer esses diversos conceitos com que você tem contato, com a fonte (Docente 5, 32 anos).

Funciona, mas eu não sou muito rígida. Já tentei atrelar isso, eu já pensei em atrelar isso a uma nota. Quando amarra com nota, aí eles cumprem mais. Se você deixar solto, um faz, outro não faz, mas eu sempre pergunto papo reto, na real. [...] Na última [turma], tinha [o conteúdo] da ética protestante e o espírito do capitalismo. Eles quase enlouqueceram, mas eu dividi o livro para que eles pudessem ler. [...] Eu sabia que era sem pé nem cabeça, mas dividi. E falei: "Não me apareça na próxima aula sem a leitura, porque senão você não terá o que fazer aqui. Combinado? Não seja cara de pau, porque você não vai me enganar. $E$, se você tentar me enrolar, eu vou fazer duas vezes a pergunta, e vai ficar muito chato para você". Quando chegaram com a leitura, a gente fez um círculo: "Vamos começar? Como foi a leitura?" (Docente 6, 56 anos).

O que eu faço? Uma pergunta sobre o tema que é óbvia: o aluno tem que ter lido o texto, senão, ele não vai responder. Ele tem cinco minutos para responder. Então, eu projeto o slide, o quiz, antes de começar a aula. É a primeira atividade individual. Ele responde e entrega. Ele quer acertar o quiz, ele quer fazer. Se ele não leu o texto, eventualmente fico provocando ao longo do tempo: no início da aula, pergunto onde está tal frase, se está no texto. E você vai checando quem leu e quem não leu. Aí, a participação é dada em função disso, ou seja, você tem que participar e se colocar. Então, você vai trazendo mais gente para a leitura (Docente 8, 64 anos).

No que tange à mediação da aprendizagem com os alunos, o D2, o D5 e o D8 comentaram que dão prioridade à exposição do conteúdo com diálogo e debates sobre exemplos reais do mercado que combinem teoria e prática.

\footnotetext{
${ }^{17}$ Termo que designa peças de comunicação que apresentam algum conceito de forma estimulante.
} 
Costumo geralmente conduzir de forma expositiva, mas obviamente sempre com participação e as pessoas também me relatando casos nas empresas. Uma aluna uma vez disse: "agora estou entendendo por que acontece isso na minha empresa; antes, eu não entendia". Combino muito a questão técnica da disciplina com o que está acontecendo no mercado e faço analogias com as questões do dia a dia da vida pessoal. Vou "costurando", trocando ideias, conversando, pedindo para eles me darem exemplos, inclusive nos seminários (Docente 2, 32 anos).

Primeira coisa que faço com eles é uma sensibilização. Quando o pessoal está todo empolgado, você começa com o conteúdo. Quando dava [aula na] sexta à noite e no sábado, podia na sexta à noite esticar um pouquinho mais e, no sábado, retornar ao tema. $E$ sempre colocava no final também uma pesquisa pra fazerem em casa sobre exemplos práticos para abrir a aula seguinte: "tragam uma ideia sobre esse tema, reflitam um pouco sobre o que a gente vai ver na aula que vem". Quando chegava na aula, sempre tinha aquela meia hora: aproveitava pra quem estivesse ali debater, quem não tinha feito, fazia na hora. Você vai entendendo um pouquinho onde estão os pontos de vista dos alunos para, na hora de explicar, reforçar aquilo que você viu que na argumentação estava fraco e trazer exemplos mais próximos do que eles imaginam (Docente 5, 32 anos).

O D8 relatou que a sua estratégia é fazer perguntas provocativas com o apoio de metáforas para manter a atenção dos alunos e facilitar ainda mais essa relação teoria-prática. Enquanto que o D5 mencionou sua capacidade de adaptar rapidamente o planejamento às necessidades dos alunos, em função do dinamismo da disciplina e do tempo restrito de aulas.

Por exemplo, o "All That Jazz" é um texto que fala sobre improvisação, mas ele vai comparar. "Qual a diferença de uma orquestra para uma banda de jazz? Por que uma banda de jazz? Porque as empresas ficaram menores? As empresas são menores, precisam de menos gente, mas precisam de mais gente qualificada. Então, por isso, é a banda de jazz. Não é sempre o mesmo cara que improvisa, não é sempre o mesmo maestro, não é sempre o cara que está na luz. A luz vai mudando. Quem é bom naquela equipe é o cara que vai fazer". Então, vou fazendo esse tipo de ponte entre teoria e prática com metáforas, e eles ficam atentos. Estou mantendo o aluno ligado. E faço conexões entre as aulas. Isso já é o gancho para a aula seguinte, que vai focar mais o assunto X. Essa é a estratégia que uso (Docente 8, 64 anos).

Mesclo aula expositiva com debate e sempre forneço ampla bibliografia para a leitura dos alunos. Depois, tenho a disciplina preparada, vou ajustando de acordo com as demandas dos alunos. Mas tem de ser rápido pra captar aquilo que eles querem e como se aplica no dia a dia. Tem professor que se alonga muito, só temos seis aulas (Docente 5, 32 anos). 
Os entrevistados foram unânimes: um dos saberes pedagógicos mais valorizados foi a relação interpessoal construtiva, especialmente entre professor e aluno. Embora com diferentes intensidades e visões, todos citaram a importância desse vínculo.

O depoimento mais significativo foi o do D7, que procura compreender a dimensão humana dos alunos para além da questão do conteúdo. De acordo com ele, as relações em sala de aula são construídas a partir da confiança que gera vínculo entre as pessoas, o que facilita a aprendizagem. Acredita que ainda que essa importância se estende às relações entre os alunos.

$\mathrm{Na}$ verdade, o que a pessoa quer é vibrar com possibilidades que poderão ser ofertadas em sala de aula não só pelo docente, mas pelo grupo das relações que estão ali. [...] Vínculo é a palavra apropriada para isso. Porque, por trás dela, vem a confiança, e aí vejo igualmente a responsabilidade, porque, se você captura essa confiança, estabelece esse vínculo (Docente 7, 57 anos).

Segundo a D6, a base da relação são a sensibilidade e a flexibilidade, que favorecem a empatia entre professor e aluno, a concentração deles e a personalização do processo de ensino e aprendizagem. Complementarmente, o D4 afirmou que ser verdadeiro com os alunos e compartilhar exemplos reais sobre o tema da disciplina é o que desenvolve a relação entre professor e aluno, construída também com atitudes simples como, por exemplo, chamar os alunos pelo nome e mostrar-se aberto a qualquer tipo de questionamento.

Eu tenho uma sensibilidade para as pessoas, então, por exemplo, costumo "sacar" quando a pessoa diz o que não está pensando. O que hoje eu mais sinto falta no mundo, [...] é a atenção das pessoas, até porque muitos com um celular passam da falta de educação. [...] Eu sou muito flexível. Minhas regras são: "administre seu horário: se você chegou atrasado, entre abaixado que é para ninguém te ver. Se precisar sair... Se alguém te ligar, tem que ser uma coisa muito urgente: se você estiver, sei lá, com o bebê para nascer, me avisa que vai tocar. Então, é mais fácil que a gente compartilhe". Sou mais flexível nessas coisas até para que eles se responsabilizem por essas questões, não deixem nas minhas costas. Agora, a atenção... [...] quando percebo que tem uma "viagem", eu paro. Às vezes, conto uma piada. Eu tenho que resgatar. Faço vários resgates durante a aula, entendeu? (Docente 6, 56 anos).

Minha estratégia é ser franco, mas não é uma estratégia, porque eu sou. Conto histórias reais que aconteceram. Eu falo: "vocês querem entender porque vocês têm que conhecer o cenário econômico? Vou contar uma historinha pra vocês. Eu tinha uma casa, vendi essa casa, 
comprei uma outra na planta, vendi essa casa por $\mathrm{R} \$ 160$ mil em 2007. Peguei o dinheiro, botei na bolsa e, uma parte do dinheiro, botei no imóvel na planta. Eu não analisei o cenário econômico. Vendi a casa em 2008 por $\mathrm{R} \$ 160$ mil e em 2010 ela valia $\mathrm{R} \$ 600$. Perdi o dinheiro na bolsa porque a bolsa despencou e não parou mais de despencar até hoje, e fiquei sem o apartamento que eu tinha comprado na planta. Vocês entenderam por que eu tenho que saber como as coisas funcionam? Legal pra vocês. Vai acontecer pra vocês, se vocês não prestarem atenção no que está acontecendo em volta." Quando eu falo isso, eu "desço", chego até eles (Docente 4, 42 anos).

A D3 procura criar um ambiente participativo, respeitando cada aluno na construção do conhecimento. Explicou que, desde a primeira aula, se preocupa em estabelecer um acordo alinhando suas expectativas sobre a disciplina, que é o começo do acompanhamento que faz durante todas as aulas, inclusive com o apoio da plataforma virtual da IES como recurso auxiliar.

Uma coisa que tem me ajudado bastante é na primeira aula construir
esse código de como é que a gente vai funcionar, pelo menos na
minha aula. [...] Então, eu passo um pouco para eles dois pontos
principais: o que é o plano de ensino (explico rapidamente) e faço a
checagem. "Era isso que vocês imaginavam, que vocês queriam
quando chegassem aqui na aula? Tem alguma coisa que eu não falei
que é expectativa de vocês?". Então, eu já firmo ali, me coloco à
disposição: se aparecer algum tema que eles consideram importante
para a formação deles, que vai fazer diferença quando eles estiverem
atuando, e se tiver tempo, a gente pode trabalhar sim em sala. Se não
houver tempo, a gente monta de uma outra forma de aprender. É como
eu brinco com eles: "Vocês têm os interesses e expectativas, mas
vamos ver até onde isso é legítimo. Porque isso pode se confrontar
com outros interesses e expectativas". Acho que [devo] criar um
ambiente de sala de aula em que todos possam participar, todos
tenham seu espaço, o seu jeito de participar, mas que todos possam
participar (Docente 3,36 anos).

O D1 nomeou como "saber das relações humanas" esse cuidado com os alunos, citando o vínculo construído, a troca de ideias e a escuta ativa como atitudes que conectam os alunos com a aula. Embora tenha certa experiência, percebe que, não tendo formação pedagógica específica, precisa lecionar em diferentes turmas para conseguir lidar com os diferentes perfis, especialmente os mais desafiadores.

Acho que tem um terceiro saber que [...] a gente precisa saber de relações humanas, a gente precisa saber de gente. Essa terceira perna, eu tenho um pouco de vivência, mas não tive formação nisso. Acho que, felizmente, eu nunca tive uma turma muito complicada, mas ouço histórias em que eu não sei se saberia lidar com algumas situações. [...] Com certeza, muito dessa intuição para lidar com improvisos vem com a prática de lecionar em várias turmas diferentes. 
Claro que a gente nunca vai estar pronto $100 \%$, faz parte da nossa profissão, mas acho que o tempo de aula vai te trazendo algumas percepções e macetes. [...] Tem uma coisa que faz parte da questão das relações humanas: cada turma, cada aluno tem dentro uma bagagem, um potencial diferente, uma história diferente, desde limitações e potencialidades. Acho que esse tipo de conexão, de troca, de escuta, é o que traz as pessoas realmente para dentro daquela aula (Docente 1, 40 anos).

O D2, o D5 e o D8 foram mais objetivos em seus comentários sobre a importância das relações em aula. O D2 explicou que procura facilitar o diálogo com os alunos mostrando-se próximo durante a exposição dos conteúdos e disposto a acompanhá-los durante toda a disciplina. O D8 mencionou o respeito desde a primeira aula, que implica confiança, e o D5 se esforça para manter-se conectado com eles. Mesmo brevemente, os três docentes demonstraram valorizar esse aspecto ao longo de seus depoimentos.

Me coloco à disposição: "Se vocês não entenderem", deixo muito claro, "me questionem, me tragam". Daí, eles vão trazendo, mas não tem uma data, um critério, não estipulo (Docente 2, 32 anos).

As metodologias de aprendizagem foram mencionadas como formatos de atividades individuais ou em grupo, quase sempre ligadas a processos de avaliação. Excetuam-se o D5 e o D7, que avaliam os alunos pela participação nas aulas e a partir do trabalho interdisciplinar, que é o modelo específico do curso que lecionam.

Como não tem prova, é difícil medir o conhecimento do aluno. [...] Nesse curso, a nota dos alunos é do trabalho interdisciplinar que fazem nos módulos, e não em disciplinas. No final as aulas, ou de uma aula pra outra, estimulava eles a refletirem para entender o quanto estavam captando de conhecimento. Mas isso muito mais informal, até pra dar algum reforço se surgisse algum conceito (Docente 5, 32 anos).

Ambos explicaram que é um trabalho vinculado ao projeto pedagógico e ao TCC, suficientemente flexível para atualizar de forma permanente o conteúdo e ter um olhar transversal para a aprendizagem do aluno, características dos cursos modulares. Ao ser perguntado sobre a adoção desse modelo em outros cursos, o D7, que é também coordenador, esclareceu que não é um padrão da IES estudada e que tampouco é aplicável a temas de caráter racional ou pragmático.

Tem um vínculo muito grande com o projeto pedagógico. [...] Se nós temos lá o trabalho de conclusão do curso, nos apropriamos de uma 
parcela disso em cada módulo. Então, o aluno já é demandado desde o primeiro dia para a construção desse trabalho, e ele sabe que já está fazendo uma parte disso. [...] Nós não temos disciplina, essa é a questão. A gente não separa o conhecimento de maneira disciplinar. [...] E dentro de um modelo: não tem o nível de detalhamento como tem a disciplina, e o módulo mais genérico me permite ser mais flexível. Mais transversal, mesmo, e mais flexível com a realidade. [...] Então, veja, dentro de um programa modular, eu consigo trazer aquilo não só como uma questão tópica, mas também como uma questão transversal: como isso está sendo trabalhado? Como estão lidando com esse tema aqui dentro? Se eu estivesse por disciplina, seria obrigado a fazer a disciplina e fazer prova no final sobre aqueles conteúdos. Eu não conseguiria garantir que aquele assunto tão importante para a sociedade estivesse sendo tratado lá. [...] Mas esse modelo não é adotado por toda instituição: ele é muito particular da nossa área. [...] Eu não sei se cabe para todo mundo, também, porque em áreas de conhecimento que são também muito racionais e pragmáticas como finanças, por exemplo, de repente isso não funcionaria tanto (Docente 7, 57 anos).

O D1, D2, D3 e o D8 adotam seminários em grupo como atividade e processo avaliativo dos alunos. O D1 relatou que compartilha um guia com orientações e referências que dão suporte aos alunos na elaboração e na apresentação dos seminários, evitando que eles sempre apenas expositivos e se tornem cansativos para os demais alunos da classe. Além disso, o docente relata que procura realizar a combinação de variadas metodologias.

Na IES pesquisada, tenho oito encontros. O que eu faço é usar dois PBL, que têm mais ou menos uma hora e meia de duração, e depois completo a aula com expositiva dialogada. Eu tenho apresentação de seminários: sempre tem uma abertura, apresentação do seminário, fechamento e [...] peço para o pessoal do seminário colocar alguma prática, alguma dinâmica, alguma atividade. Porque uma crítica de seminário [...] é que é bom pra quem está apresentando é ruim para quem está vendo. Então, eu procuro desenvolver uma guia de seminário: "espero que você aborde tais temas", porque o grupo que está apresentando a partir do nada. Dou algumas referências e peço para eles buscarem outras. Peço para eles desenvolverem uma atividade de 10 a 15 minutos com a turma e daí eu ajudo eles na atividade. A primeira turma que eu peguei na IES pesquisada foi burocrática, e as apresentações eram meio chatas, tanto a apresentação quanto a dinâmica. Essa última turma, para mim, foi excepcional - foi um ponto fora da curva. Os caras superaram muito as minhas expectativas na qualidade do seminário e na elaboração das atividades. Acho que, de todos os grupos, teve um que não me procurou para tirar uma dúvida ou para pedir uma orientação. Todos os outros chegaram com dinâmicas [...] de certa forma surpreendentes e divertidas com a turma, de forma que o seminário que era para ter menos de uma hora, às vezes se alongou porque eu aproveitava para começar uma parte de exposição de conceito. De forma que uma aula de três horas e meia, quatro horas, foi composta por dois seminários 
e muita discussão. Então, essa turma, pra mim, foi surpreendente (Docente 1, 40 anos).

A aplicação de metodologias ativas de aprendizagem é bem vista pelos alunos, de acordo com o D1 e o D8. Mas nenhum dos entrevistados citou expressamente a responsabilidade do docente como facilitador do engajamento dos alunos, aspecto crítico integrante dos saberes pedagógicos, conforme afirmado por Masetto (2003) e Rogers (1985).

Eu não quero que ele chegue amanhã e faça: eu quero que ele chegue amanhã e pense. Quero que ele pense diferente, e essa é uma outra coisa que eu acho que a coordenadora do curso superacolheu. Então, quando fui justificar por que usar uma metodologia ativa, eu falei "Porque quero desenvolver neles senso crítico". Talvez eles não cheguem, mas tentam, porque vai ser muito legal se der certo (Docente 1, 40 anos).

No lato sensu, é diferente a atitude e a relação com os alunos. [...] Você trabalha com formatos ativos, trabalha com seminário, com discussão, eles têm que se colocar mais (Docente 8, 64 anos).

A D3, a D6 e o D8 aplicam atividades que combinam trabalho individual e em grupo, utilizadas no processo avaliativo. Segundo o D8, 40\% da nota da disciplina se deve à dedicação individual e 60\%, em grupo, proporção análoga às atividades da realidade empresarial, o que é coerente com o propósito dos cursos lato sensu. Em particular, ele propõe variadas metodologias: quiz, exercícios, seminários e um trabalho final em sua disciplina.

Quando ponho uma estratégia de avaliação, eu explico por que vamos trabalhar isso. Para você ter uma ideia, na disciplina que encerrei ontem, eu faço normalmente duas avaliações, uma individual e uma em grupo, porque [...] eu percebo que o indivíduo se perde muito no grupo, se dilui. Conhecimentos específicos, eu não consigo muito medir o indivíduo no grupo, aí eu crio dois momentos: um é em grupo e um é individual (Docente 6, 56 anos).

Avalio a participação no quiz, seminários, exercícios e trabalho final. Esse exercício final que também é conhecido como prova. Isso é uma questão de nomenclatura. Digo: "vocês repararam que a avaliação individual soma $40 \%$ e a avaliação em grupo soma $60 \%$ ? Porque algumas coisas, $60 \%$ delas, [...] numa organização, você vai fazer junto com outras pessoas. Mas tem até $40 \%$ de coisas que você vai ter de fazer sozinho. Você vai se sentar, olhar para o computador e vai ter de decidir e assinar. Mas a maioria das coisas você vai fazer em conjunto" (Docente 8, 64 anos). 
Ainda sobre as metodologias e recursos, o estudo de caso foi mencionado pela D3 e pelo D4 e, segundo este, permeia todas as aulas, favorecendo a aprendizagem da teoria ligada à prática de trabalho. Já a D6 comentou que apresenta trechos de vídeos e notícias de jornal, que favorecem a compreensão da realidade empresarial e atraem a atenção do aluno.

O que eu costumo fazer é ficar o tempo inteiro resgatando um exercício. Por exemplo, nessa disciplina, dou um DRE para eles que é um demonstrativo de resultados esperados: é uma planilha pra calcular rentabilidade, para fazerem a gestão. Entrego no primeiro dia de aula e aí, quatro ou cinco vezes por aula, eu trago daquele assunto que está sendo abordado no DRE. Esse é um jeito de fazer o aluno usar a planilha e de fazer ele entender que, se ele tiver oito horas a mais de gente, pagar oito horas a mais de um funcionário: durante um ano, isso vai ter um impacto de tantos reais na minha rentabilidade. Assim, eu consigo forçar o aluno a trabalhar a informação que ele está recebendo. Aí, eventualmente, alguém faz uma pergunta, o outro retruca, e eu deixo rolar, porque para mim é uma boa demonstração de que eles estão acompanhando (Docente 4, 42 anos).

A preocupação que eu tenho é assim: tenho um conteúdo formal para cumprir, mas, por serem adultos, [...] alguns até mais maduros, tenho uma preocupação muito grande de encontrar recursos, meios que tornem aquilo o mais próximo possível da realidade deles, para que tenha eco, para que, no mínimo, faça-os questionarem sua prática [...]. Aí, eu recorro a vídeos, recorro a notícias do jornal, da atualidade, tento fazer o máximo link possível com a realidade às vezes até empresarial, quando coincide. Por isso eu digo que nunca consigo fazer o mesmo, igual, do mesmo modo, porque o tempo está diferente, as notícias são outras, outras coisas acontecendo. Tentar vincular, na verdade, com a realidade deles, porque, senão, eu não consigo atenção deles (Docente 6, 56 anos).

A metodologia mais complexa e original citada pelos entrevistados foi a aprendizagem baseada em problemas (PBL), adotada pelo D1. Ele que passou a implementá-la na outra IES em que leciona, para contornar um imprevisto em que se sobrepôs conteúdo com outra disciplina. Por iniciativa própria, pediu o apoio do núcleo pedagógico para adequar a estratégia a sua necessidade. Nesse caso, ressaltamos a importância de um acompanhamento pedagógico disponível na IES e do tempo necessário ao desenvolvimento da metodologia, como acontece quando o docente é contratado pela CLT (o caso do D1, em uma outra IES).

Eu falei "que legal, um dia, quando estiver preparado, eu vou implantar". Então eu fiz uma academia sobre o método PBL. [...] O jeito que ela aplicou, achei muito inteligente. Ela problematizou assim: "você é de uma instituição que está passando por um processo de mudança... E você, como professor, vai ter que discutir a adoção de 
metodologias ativas. E ela contou essa discussão de um [jeito] superlegal. Ela falou assim "isso é um exercício, isso é parênteses, vou falar para vocês como se conduz o exercício". Caiu a ficha, não é tão difícil. Precisa de uma preparação, mas rola. Acho que é disso que eu precisava. Mas ainda fiquei com aquela sensação de "quando eu estiver preparado", "quando eu estudar", "quando eu for um grande professor" [...] vou fazer. A turma seguinte foi uma turma difícil [...] e, na minha segunda aula, os alunos vieram com uma postura de "tem muita sobreposição" - era o mesmo assunto visto de outro ângulo. [...] Falei "cara, isso nunca mais vai acontecer: vou adotar aquele negócio agora". Nessa última turma, em duas semanas, eu desenvolvi um PBL [...]. Fui ao núcleo de práticas pedagógicas, peguei um cara "no laço". Ele falou "não, agora estou meio enrolado". Peguei no laço. Ele se sentou comigo aqui, revisou, foi para o meu coordenador, colocou resistência e falou "meu, essa disciplina... você é maleável?, é uma dor de cabeça". Falei: "Fulano, a gente precisa". Ele: "não, deixa o Beltrano [que é o professor referência dessa disciplina] começar [...] e, depois que estiver arredondado, você usa". Respondi: "não, não vou deixar. Quero fazer agora. Está aqui". Ele falou: "mas vai ter que desenvolver". Respondi: "não, está aqui, está desenvolvido, está alinhado com o núcleo, e vou fazer daqui a uma semana" (Docente 1 , 40 anos).

Esperava-se dos docentes do lato sensu uma combinação maior de metodologias e recursos didáticos, como o uso de mapas conceituais, pesquisa de campo, visitas técnicas e condução de projetos complementares.

Outro fator que deixou a desejar foi a inclusão digital. Ao contrário do que se esperava, apenas dois docentes mencionaram o uso de recursos tecnológicos como apoio às aulas. A D3 e o D7 comentaram que aproveitam a plataforma virtual da IES para compartilhar material, comunicar avisos importantes e interagir com os alunos por meio de mensagens e fóruns de discussão sobre temas relevantes.

A gente utiliza muito o recurso digital, como eu te falei. Então, interajo com eles antes de estarem em sala e continuo interagindo com eles depois de estar em sala. Nosso ambiente virtual de aprendizagem [da IES] permite que eu me prepare. Não faço só postagem, não uso só como repositório de determinadas publicações, mas sim como ferramenta de aviso: eu me apresento coloco o meu currículo, faço uma apresentação prévia para, no primeiro dia eles já terem visto, e a gente ficar evitar ficar falando de mim mesmo. Então, já vou ao ponto, já começo a fazer algumas provocações. [...] Durante [a aula], vou colocando sim material, tudo o que eles recebem. Às vezes, também preparo os encontros futuros e às vezes utilizo de algumas ferramentas que o sistema permite [fóruns, web conferências - que são, digamos, instrumentos adicionais para isso]. [...] Essas coisas precisam ser sempre bem fortalecidas. Gosto, no primeiro dia de encontro com eles (eu já preparei o sistema de avaliação), de falar quais são só critérios, o que vai ser. [...] O primeiro dia é de integração. 
Ele já sabe qual é o plano dele, então, isso às vezes requer um planejamento um pouco maior e aí, demandar da estrutura da instituição respostas para algumas perguntas que poderiam ser traçadas no tempo, mas que você traz, antecipa e já garante articula com a instituição: tal dia, vai precisar disso. E a informação está lá [na plataforma virtual da IES] (Docente 7, 57 anos).

No universo digital em que se encontram os alunos do lato sensu, é uma ferramenta útil de apoio à aprendizagem. No entanto, alguns docentes convidados comentaram que não sabem manuseá-la, diferentemente da D3 e do D7, que são celetistas, o que permite inferir que têm mais tempo para entender o funcionamento da plataforma virtual ou que estão mais próximos das orientações administrativas da IES. Outro recurso que não foi mencionado e que existe em quase todas as salas de aula da IES selecionada foram os quadros smart board, equipamento de apoio que favorece a interação do docente com a exposição na tela.

Como a IES não padroniza um processo avaliativo nos cursos lato sensu, os docentes podem escolher conforme a preferência. O D1 avalia pela participação no grupo na resolução de dois PBL e nos seminários. Já o D2 observa questões técnicas, de conteúdo, e comportamentais na apresentação dos seminários e afirmou que não reprova nenhum aluno, mas dá notas coerentes com o desempenho dos alunos e passa sua mensagem no fim da disciplina: a atuação em sala de aula é um reflexo da carreira profissional, que pode ou não render bons contatos de trabalho.

Na última, aula peço que eles me apresentem, façam um seminário. Por exemplo, na primeira aula, já coloco, trago para eles, não dou prova escrita, não trabalho dessa forma, mas eu exijo um seminário na última aula, com nota, e nesse seminário eu não avalio somente a questão técnica. Avalio postura, o saber falar, saber se expressar. [...] Ali eles podem errar, ali é o momento. A partir do momento em que você se torna um especialista, vai para a empresa, e lá é mais difícil. [...] Eu escolho algumas empresas, formo grupos e seleciono para que façam uma análise e apresentem no seminário com alguns critérios de análise e interpretação. Esse formato tem funcionado, e as pessoas vêm gostando. Tive o feedback de uma aluna. [...] Eu não reprovo as pessoas, pelo menos por nota: eu jogo a nota lá pra baixo... E eu diferencio, obviamente. Isso faz parte. Recebo muitos pedidos de revisão, mas "desculpe, não faço". Na última aula, costumo dizer "parabéns gente, quem sabe a gente se encontre no mercado". Fica como recado (Docente 2, 32 anos).

Para a D3, a avaliação começa já no levantamento do conhecimento prévio dos alunos, com a aplicação de um questionário no início da disciplina, o que mostra uma 
prática da andragogia, citada pela docente. A nota dos alunos é resultado de uma resenha e da análise de um estudo de caso, de que a docente vai exigindo de maneira crescente à medida que avança a complexidade do conteúdo. Mas a D3 afirmou que valoriza antes a construção da aprendizagem dos alunos que a nota. Por isso, esclarece antecipadamente os critérios das entregas, abre possibilidades de execução com flexibilidade de prazos, faz um acompanhamento próximo e formaliza sua avaliação com cada aluno.

Em geral, eu faço um trabalho; se dá para explorar esse trabalho em
sala de aula, eu dou preferência, nem que seja uma parte de "vamos
fazer juntos", porque é uma possibilidade de eles tirarem dúvidas e
adiantarem o trabalho. Outra coisa é "se vocês vão entregar, podem
passar uma prévia": eu faço uma orientação e, sempre que faço
alguma atividade, tem o que eles têm que fazer e os critérios pelos
quais eles vão ser avaliados. [...] A nota deles estará vinculada
àqueles itens. [...] Eu me preocupo em dar alguns caminhos e dizer a
eles: "Esse é um caminho. Você pode me apresentar outros dentro
desses critérios, desse escopo que eu estou te apresentando". Outra
coisa também que eu me cobro é sempre formalizar esse feedback
para eles, porque acho que é uma coisa importante eles saberem...
Como a gente usa muita ferramenta virtual da IES, é por lá. Eu
formalizo por lá e falo dos pontos fortes, falo daquilo que eu entendo
que pode melhorar. Não é a nota, é a construção do conhecimento
deles que importa (Docente 3,36 anos).

Dois docentes apresentaram uma visão mais crítica sobre o processo de avaliação. O D4 discorda da aplicação de prova em cursos de pós-graduação e, por isso, pede a apresentação de um trabalho em forma de estudo de caso com os temas abordados na disciplina.

Normalmente, eles apresentam o trabalho que é a análise de uma empresa. Dentro dos temas que a gente trabalha, ele pode escolher e diz: "esse, vou analisar isso", "esse, vou analisar aquilo", é um case. Eu sou contra prova. Acho que prova não prova nada: prova quem decorou melhor. Acho que, na pós-graduação, não tem sentido (Docente 4, 42 anos).

A D6 se pergunta quais seriam os reais objetivos e os critérios justos que de fato avaliam a aprendizagem desses alunos do lato sensu e pensa que deveria saber mais sobre o assunto para fazer a escolha correta. Portanto, adota formatos diferentes, como o citado diário de bordo com relatos de aprendizagem, e costuma explicar aos alunos a estratégia de avaliação que aplicará com o porquê da escolha. 
Então, eu sentia muita falta de avaliação [na disciplina lecionada], momento avaliativo, estratégia de avaliação... Me perguntava muito por que eu tinha uma preocupação muito grande de ser injusta com o aluno. De repente, vou me prender a uma data? Posso até me prender, mas qual o objetivo, qual o tipo de pergunta para aquela data? É memorização, não pode ser outra coisa. É importante? Se for importante, a gente vai pedir a data, mas, não sendo... Então, [...] notei que eu não sabia fazer avaliação. Não sabia. [...] Eu ia fazer uma avaliação de conhecimento específicos, mas a sala tinha alguns pontos, algumas pessoas que têm o "narizinho torcido"... "O que nós vamos fazer? Gente, vamos trabalhar com diário de bordo?" [...] Aí, eu consegui convencê-los de que o diário de bordo, para eles, seria a melhor avaliação individual. Dei a estrutura, expliquei como funcionava, "não quero que vocês relatem conteúdo para mim: eu quero saber o que foi para a sua cabeça das aulas e das pós-aulas em relação à disciplina. Eu quero saber das suas reflexões, das suas dúvidas, dos seus pensamentos. Conteúdo eu tenho, eu sei, não precisa me ensinar, me falar nada. Mas, se você fez pesquisas adicionais, eu quero conhecer, quero saber. Dúvidas: como você sanou? Se não sanou, por que, em que momento... É isso que eu quero num diário de viagem". [...] O diário de bordo é uma estratégia muito usada na educação infantil, mas funciona muito, com as respectivas adaptações. E funcionou! É um negócio surpreendente (Docente 6, 56 anos).

Em suma, verificamos que cabe ao docente decidir sobre a estratégia educacional, as metodologias de aprendizagem aplicadas e o processo de avaliação da disciplina lecionada. De acordo com os relatos dos entrevistados, eles de fato têm autonomia, e sabemos que não existe um padrão mínimo exigido pela IES ou pelo MEC. Como nem todos parecem seguros de suas escolhas, talvez não estejam bem preparados, e isso pode estar comprometendo o processo de ensino e aprendizagem.

Certas afirmações dos docentes mostraram uma atitude reflexiva sobre seu trabalho, como já exposto. A D3 e o D5 reforçam que a carreira docente contribui para a carreira de consultor empresarial e vice-versa. E, para ambos, sua preparação nas duas profissões concorre para seu desenvolvimento.

É um método também para eu me desenvolver e para eu me manter atualizada. Porque as dúvidas dos alunos também vão me reciclando. É uma forma de eu me reciclar, de eu me manter muito atual, porque eu sabia que tinha que entrar em sala, então, eu ia fazer uma única coisa que era me preparar bastante: estudar para as aulas e, com isso, me manter bem atualizada tanto na parte de consultoria como na parte de docência. Vai muito do feeling [...] o que dá certo e o que não dá certo. Os públicos, eles são diferentes, e eu acho que, em consultoria, a gente tem que desenvolver um feeling de perceber cada ambiente. Eu passo por clientes diferentes, segmentos diferentes, modelos de negócio diferentes. Faço uma leitura boa e rápida, então, acho que 
isso também acaba sendo um diferencial que faz com que essa ponte entre o mercado e à docência ao lato senso funcione muito bem (Docente 3, 36 anos).

O que gosto mais quando dou aula é que me obriga a me sistematizar mesmo. Tudo bem que, num projeto de consultoria, você sistematiza muita coisa, você estuda a empresa, vai mais no negócio e menos na técnica. Mas, quando você tem de dar aula, você precisa juntar tudo isso. Então, isso acho legal também. Por isso, uma das coisas que me chama agora para o mestrado é isso: são momentos que você estuda três ou quatro anos lendo, mas chega um momento em que você precisa organizar e sistematizar, até pra poder somar mais conhecimento (Docente 5, 32 anos).

O D5 acredita que o mestrado melhorará sua capacitação para a docência e seu reconhecimento pela titulação.

Quero "pegar" mais aulas: esse é um dos motivos pelos quais estou procurando mestrado. Além do saber, é estar capaz de dar aula mesmo e eu acho que é importante também ter os estudos. E, pra algumas instituições, faz muita diferença o título (Docente 5, 32 anos).

Como vimos, o D1 e o D7 criticaram o stricto sensu por não preparar devidamente para a docência. Esses docentes (D1 e D7) foram os mais reflexivos dos entrevistados. Para o D1, o professor é apenas um coadjuvante do processo de ensino e aprendizagem, pois o objetivo é ela ter sentido para o aluno. Mas, para isso, reconhece que precisa de mais experiência como docente para desenvolver seus saberes pedagógicos, apesar de considerar-se em constante aprendizagem e nunca totalmente pronto.

\footnotetext{
O meu referencial não significa nada, e eu acho que tenho que partir desse espírito. Acho que, quando você parte desse espírito de forma legítima, ganha jogo de cintura. Tudo bem, vou falar disso e, se as pessoas não souberem, eu me viro na hora. Tem gente que trava, e tem professor que fala coisas do tipo "poxa gente, vocês precisam estudar mais, precisam conhecer referência, precisam conhecer o mundo" - acabou de criar uma muralha entre professor e aluno. Acho que tem um pouco disso, de estar aberto e enxergando pessoas, gente de verdade, com necessidades. Então, conhecer o perfil do aluno, saber de onde ele é, no que ele trabalha, quantos anos tem ajuda. Mas não adianta ter essa ideia e depois se desconectar na hora da aula. $\mathrm{O}$ professor só é coadjuvante, aquilo tem que ter sentido para o aluno (Docente 1, 40 anos).
}

O docente afirmou que, a partir da aplicação de metodologias ativas de aprendizagem em suas aulas, passou a ser mais exigente com os alunos, de quem agora espera uma responsabilidade compartilhada na construção do pensamento 
crítico. Ele espera que o aluno volte a seu trabalho pensando de forma diferente, e não apenas aplicando as ferramentas aprendidas no curso.

Quando falo em metodologia ativa, todo mundo é responsável pelo aprendizado. [...] Eu não quero que o aluno chegue amanhã na empresa e faça: quero que ele chegue amanhã e pense diferente. Estou cobrando muito mais e, ainda assim, eles estão gostando. Então, é porque está funcionando. Estou só arranhando a superfície, tem muita coisa pra fazer. "Agora está legal", de repente eu descubro que... Estou descobrindo coisas que eu nem sei se existem (Docente 1,40 anos).

A postura reflexiva do D7 se revela no caminho que percorre para o autoconhecimento e para seu desenvolvimento continuado, tanto na vida pessoal como na docência. $O$ docente afirmou que ser também coordenador favorece sua visão integrada da construção do conhecimento (que prefere à visão mais pragmática dos alunos) e o ajuda a perceber rapidamente relações entre a teoria e a prática profissional.

A coordenação é importante porque me possibilita o olhar como um todo ao processo de construção do conhecimento e saindo um pouco desse mundo material e pragmático que o lato sensu sempre cobra. Então, preciso responder aqui que, no fim [...] acabou existindo uma identificação maior com essa questão mais intelectual, com o conhecimento como um todo, dessa visão de concepção mais integrada. Quer dizer, daqui [do lato sensu], consigo visualizar melhor o mundo prático. [...] Então, eu hoje estudo mais o mundo teórico, mas me sinto confortável por isso, porque eu faço uma ligação mais rápida com mundo prático. [...] Porque, da leitura dada ao meu percurso profissional, da leitura do conceitual, eu consigo fazer conexões mais rápidas (Docente 7,57 anos).

Os saberes pedagógicos foram valorizados pelo D1 e pelo D5, que questionaram a prática de certos docentes com estilos de ensino ineficientes. Para o $\mathrm{D} 5$, alguns professores procuram ser divertidos e não se preocupam com o ensino ou a aprendizagem, enquanto outros são muito técnicos e não conseguem transmitir seu conhecimento. Acredita que o ideal seria uma combinação dos saberes, conseguindo ensinar de forma que os alunos se mantenham atentos.

Vejo aula como espaço de troca de conhecimento, mesmo. Tem aqueles professores que são gente boa, mas que, pra mim, não adicionam muito. É até divertido, você dá risada na aula. Tem aqueles que são essencialmente técnicos, que você vê que têm um conteúdo profundo, mas não te passam nada. $E$ tem o meio termo: o que conhece a técnica, mas consegue passar o conhecimento para o aluno 
porque está o tempo todo em contato com ele. Contato visual, que na sala o cara começa a perguntar coisas, começa a querer voltar pra aula, e não simplesmente "minha aula é essa, leio, enfim, acabou" (Docente 5, 32 anos).

O D1 criticou a formação tradicional de professores, focada nos saberes disciplinares, e a resistência dos docentes a substituir a exposição de conteúdos pelo uso de metodologias ativas de aprendizagem.

Acho que hoje a formação tradicional preza muito a técnica. Quem tem técnica está habilitado a dar uma aula expositiva chata, porque ele vai querer passar conteúdo. Tem uma hora e meia, três horas para falar daquele conteúdo como está no livro, como está no artigo. E é diferente quando você tem uma visão [pedagógica]. Aí, acho que, ao final do encontro, a pessoa tem que ser capaz de se virar para ela e conseguir fazer aquilo (Docente 1, 40 anos).

Os depoimentos dos entrevistados confirmaram a suposição de que os saberes pedagógicos dos docentes do lato sensu são heterogêneos e necessitam ser desenvolvidos, construídos na prática da sala de aula e de acordo com a necessidade ou interesse do momento, sem o apoio de uma formação pedagógica consistente. 


\subsubsection{Papel dos saberes pedagógicos e autorreflexão docente}

Solicitamos aos docentes entrevistados que refletissem sobre o papel dos saberes pedagógicos no processo de ensino e aprendizagem. Assim como nas outras perguntas sobre saberes pedagógicos, foi preciso extrair informações no decorrer da entrevista, muitas vezes implícitas nas falas.

Todos os docentes mostraram perceber a importância dos saberes pedagógicos, mas com um conhecimento restrito ou parcial sobre o tema. Em alguns casos, constatamos que não os distinguiam dos saberes disciplinares e experienciais. Isso pode ser explicado pela afirmação de Masetto (2003), de que, desde o início, o ensino superior no Brasil privilegiou o domínio de conhecimento e experiências profissionais para a docência.

Apenas o D4 se posicionou claramente e diferentemente dos demais. Afirmou que, em cursos lato sensu, os saberes disciplinares e os experienciais são mais importantes no processo de ensino e aprendizagem do que os saberes pedagógicos. Explicou que isso se deve à especificidade do conteúdo da disciplina que leciona e à expectativa pragmática dos alunos nesses cursos.

A característica das disciplinas com as quais eu trabalho, não que não seja importante a questão pedagógica, mas elas são muito especificas, mercadológicas. Então, vale mais pra ele [aluno] que eu conte a história do meu jeito, que eu conte as minhas experiências, que eu diga "isso aconteceu comigo e a minha reação foi essa. $\mathrm{Na}$ minha carreira, errei aqui, acertei ali". Percebo que, pra eles, isso é importante. Porque eles percebem quando eu trago isso, todos os fatores que você tem que levar em consideração na gestão, mas também tudo o que acontece alheio à tua gestão que vai ter influência no negócio (Docente 4, 42 anos).

Além disso, questionou a utilidade dos saberes pedagógicos considerando suas referências negativas, pois acredita que são saberes desatualizados e que distanciam o professor do aluno.

Eu não sei até que ponto as práticas pedagógicas tradicionais e tal me ajudariam. Talvez, meramente uma suposição. Minha impressão é que afasta do aluno. Eu observo que as próprias pessoas que dão esses treinamentos aqui [formações da outra IES onde atua] são pessoas que não têm um bom relacionamento com os alunos, porque eles estabelecem aquele distanciamento entre professor e aluno. Tenho a impressão de que muitas das práticas pedagógicas não acompanham o momento, embora eu não seja um profundo 
conhecedor, evidentemente, mas sou um observador, porque até que elas sejam validadas, a dinâmica do mundo é outra (Docente 4, 42 anos).

O D7 afirmou que, no processo de ensino e aprendizagem, não poderia atribuir importância apenas aos saberes pedagógicos. Como coordenador, recebe feedbacks dos alunos sobre os docentes, e os positivos não se restringem aos saberes pedagógicos, mas se estendem aos disciplinares e aos experienciais. Complementou que sempre existem diferenças na percepção dos alunos, que valorizam diferentes aspectos, mas acredita que a gestão de sala sempre é um diferencial na docência.

Eu não consigo fazer uma relação tão precisa, não. Porque o que eu recebo como feedback positivo é [...] "o prof. A tinha de fato uma gestão de sala maravilhosa, o prof. B tinha um conhecimento aprofundado de tal magnitude que encantou pelo nível do seu argumento, estando sentadinha lá como se fosse a aula antiga". Claro que varia. Os bem avaliados permanecem bem avaliados, isso é verdade, mas de formas diferentes, em dimensões diferentes. As pessoas também mudam, mas eu poderia estabelecer uma relação de que o sucesso daquele tem a ver com a existência de uma gestão de sala, digamos assim. Mas não usar essa expressão "mais competente do que o outro", não posso afirmar isso (Docente 7, 57 anos).

Com exceção do D4, o próprio D7 e os demais docentes $(87,5 \%)$ reconheceram em seus relatos a importância dos saberes pedagógicos de docentes do lato sensu no processo de ensino e aprendizagem.

O D1, o D2 e a D6 criticaram os docentes que adotam uma postura tradicional de ensino, centrada neles próprios, e não nos alunos. Segundo o D1, esse é um paradigma a ser transformado a partir da ressignificação da identidade docente.

[...] Ouço que minha aula é meio caótica, mas no final os alunos elogiam muito e falam "foi tão bom, é porque você não é professor". Não! Eu sou professor! Precisamos ressignificar esse negócio, porque isso é ser professor (Docente 1, 40 anos).

O D2 observou que os docentes mais acadêmicos e focados na teoria não são bem avaliados pelos alunos. Esse é um desafio para ele, que gostaria de ajuda para desenvolver seus saberes pedagógicos, o que lhe facilitará traduzir o conteúdo técnico de sua disciplina de modo que os alunos o entendam melhor.

A gente tenta fazer com que os alunos não entendam que a nossa matéria, seja um monstro cabeludo. [...] Tento trazer, por exemplo, o DRE, que é o demonstrativo de resultado, fazendo uma analogia com 
o holerite. Mas talvez eu precise melhorar nessas questões mais técnicas, que realmente não são e talvez nunca tenham sido abordados por eles, principalmente os alunos que fazem psicologia. Essas questões mais técnicas que talvez surjam no dia a dia deles são mais complicadas. Isso, que eu preciso [desenvolver], mais uma vez, se puder me ajudar com estratégias, metodologias, agradeço. Porque é difícil (Docente 2, 32 anos).

A D6 questionou a atitude de muitos colegas que detêm saberes disciplinares e experienciais, mas com saberes pedagógicos frágeis.

Uma coisa que eu sinto falta, que eu acho que poderia ser oferecido
pela IES, são essas formações, eu não digo tão extensas, mas mais
spot para os professores do lato sensu. Porque muitos vêm do
mercado de trabalho, eles têm muito conhecimento da prática, muitos
até reúnem conhecimento teórico, mas é diferente. Por exemplo,
quando você vai discutir uma avaliação. Por que avaliar? Como
avaliar? Quando avaliar? Essas perguntas. É nota? É conceito? Qual
a diferença entre um e outro? Você vai avaliar pontualmente uma
questão ou você quer ver o processo? A gente não discute isso e, de
vez em quando, esbarra em alguns professores que tem uma postura
até "terrorista", que usam o nome da avaliação para o terrorismo, que
não tem nada a ver. Daí, eles [alunos] nos odeiam desde
pequenininhos... (Docente 6, 56 anos).

Em conformidade com as propostas de Rogers (1985), Masetto (2003) e Tardif (2002), 62,5\% (D1, D3, D5, D7 e D8) dos docentes mencionaram a importância de centrar o processo de ensino e aprendizagem no aluno, dimensão relevante dos saberes pedagógicos para docentes do lato sensu.

Brevemente, o D5 afirmou que os saberes pedagógicos são fundamentais para dar ao aluno uma visão integrada do conhecimento, a partir do planejamento e da estruturação da disciplina.

É fundamental. Isso é uma coisa com que tenho a maior preocupação, quando vou dar aula como professor convidado (Docente 5, 32 anos).

Para o D7, esses saberes desenvolvem a compreensão do processo de aprendizagem centrado no aluno adulto, além das habilidades de pesquisa, planejamento e avaliação, que imprimem qualidade ao plano de ensino. Ele demonstrou uma percepção ampliada ao declarar que o recurso a diferentes metodologias que levem à aprendizagem de forma assertiva também concorre para uma visão humana e integral do aluno. 
Com os saberes pedagógicos, entendo que as habilidades de pesquisas são favorecidas, na medida em que compreendem demandas do processo de aprendizagem, especialmente de adultos e dos alunos que buscam esses cursos. Assim, se habilita a orientar-se pelas necessidades do aluno, e não apenas por seu modelo de conteúdo. Igualmente, seu plano de ensino ganha qualidade, na medida em que amplia a competência de planejar e avaliar. [...] Amplia as possibilidades de resultado, pois considera o aluno como ser humano integral, dotado de conhecimento, experiência e consciência. [...] Compreende com mais efetividade as diferentes formas de construir vivências assertivas de conhecimento (Docente 7, 57 anos).

Do mesmo modo, a D3 acredita que os saberes pedagógicos capacitam o docente a conduzir o processo de ensino e aprendizagem, pois ele conhecerá o modo como os adultos aprendem e se sentirá preparado e seguro para lecionar com o apoio de métodos pedagógicos.

Para mim, é igual a ter domínio sobre o tema que eu vou abordar em sala de aula. Quando você entra preparado, você sabe como funciona o aprendizado para um adulto, você sabe qual o caminho de planejamento que você tem que percorrer para construir aquela aula ou aquela disciplina, isso te dá um conforto e uma segurança de que você está... Porque, se você está usando o método, aí você tem mais tranquilidade para fazer os ajustes necessários de acordo com cada perfil de turma. Mas, sem método, é muito tentativa e erro, e isso é desgastante tanto para o professor quanto para o aluno. Então, ter esse método, ter o saber pedagógico, acho que ajuda muito nisso. É você ser mais assertivo naquilo que você está querendo propor em sala de aula (Docente 3, 36 anos).

A partir de feedback dos alunos, o D8 destaca, sobre o papel dos saberes pedagógicos, a capacidade de compreender os alunos e de ter com eles um bom relacionamento interpessoal.

Um dos alunos dessa última turma em que lecionei escreveu isso: "Aprendi diversas coisas ao longo desses meses de aula. Primeiramente, estudar, manter a concentração, lembrar como escrever com caneta e papel. Sobre a matéria em si, pude observar os conceitos, analisar as experiências que li, os métodos nas empresas em que trabalho. Um dos objetivos que tenho alcançado com a pós-graduação é me formar profissional e depois lecionar. Primeiro, voluntariamente, pra aprender, e depois pra graduação. Portanto, o que levarei como maior lembrança do módulo é o modo como o professor domina a matéria, a maneira que entende os perfis dos alunos, fazendo com que todos participem das aulas e se sintam à vontade. Pretendo ser um dia um professor que inspira os alunos assim como você inspirou" (Docente 8, 64 anos). 
O reconhecimento da importância dos saberes pedagógicos incluiu a formação continuada dos docentes do lato sensu em ações promovidas pela IES, no stricto sensu e em atividades em que os professores se engajam por iniciativa própria.

Doutorando e docente há 3 anos, o D1 propõe que a formação pedagógica seja obrigatória em todos os programas do stricto sensu. Segundo ele, esses programas oferecem disciplinas mandatórias, mas não formam profissionais completos, especialmente para a docência.

Vejo que, em alguns lugares, na pós stricto [sensu], a parte de
pedagogia de ensino é obrigatória. Acho que isso tinha que ser
condição sine qua non. [...] uma das críticas que eu faço a algumas é
que tem muita coisa obrigatória, mas você forma profissionais pela
metade. Administração, você forma um aluno que é especializado em
"quanti", mas não faz ideia do que é "quali", ou o contrário. Você faz
um professor que nunca viu didática na vida (Docente 1,40 anos).

Mesmo com diferentes idades, formações e tipos de contratação, o D5 e a D6 têm propostas similares sobre ações contínuas que promovam a aprendizagem colaborativa entre pares. Ambos sentem necessidade de uma relação mais próxima entre os docentes do lato sensu para conversarem sobre interdisciplinaridade, trocarem experiências sobre a docência e poderem acompanhar aulas dos colegas para conhecer antes os alunos e aprender com os saberes pedagógicos de outros professores. O D5 defendeu que essa responsabilidade caberia à própria IES pesquisada, que incumbiria o coordenador do curso de organizá-la. Mesmo sendo docente convidado, contou que participa das ações oferecidas, por iniciativa própria, e pretende continuar participando, pois acredita que sejam úteis para seu desenvolvimento.

Seria melhor ainda se a gente tivesse uma reunião com todos os professores do curso. Acho que ter esse momento é muito importante, mas teria que partir da IES. É o que é melhor para o curso é melhor para o aluno. E melhor para o professor também, porque é muito melhor você estar seguro e confortável com o que você está fazendo, além de não repetir o mesmo conteúdo (Docente 5, 32 anos). [...] Fui de graça, mas vi a apresentação do trabalho do pessoal, o feedback do trabalho deles. Me apresentei pra turma, já conheci, assim facilita. [...] Ver a didática do outro professor, como o pessoal está acostumado. [...] Qualquer coordenador de curso tem de ter esse papel, mesmo, de garantir que o professor [...] [esteja] dentro desse time. Sei que também é um desafio, porque, como trabalho muito com projeto e preciso contratar consultor, [...] principalmente agora, neste momento de crise, acaba que o consultor fica fora do contexto. Por 
isso, eu acho que o papel do coordenador é não deixar o professor ficar fora de contexto (Docente 5, 32 anos).

Docente há 14 anos, com dedicação de 30 horas semanais e a única da amostra que começou a lecionar com preparação pedagógica prévia, a D6 demonstrou valorizar os saberes pedagógicos por sua própria trajetória formativa: é pedagoga, mestre e especialista em docência do ensino superior. Ela afirmou que sente falta de formações pontuais oferecidas aos docentes do lato sensu pela IES, onde é contratada pela CLT.

Exatamente. Então, essa daí foi uma oferta que eu gostei [especialização em docência no ensino superior], eu abracei, eu adorei o curso. Depois, fui fazer pedagogia [graduação], porque eu queria entender um pouco lá na origem, na infância, mesmo. [...] Todo mundo gostou. "Precisamos promover mais". Aconteceu? Não aconteceu. Aí, faz um grupo no WhatssApp. Ninguém fez nada. E a gente não se falou mais. E as pessoas comentavam ideias boas [...]. "O que você fez de bom? E o que não funcionou comigo e por quê? Então, tem coisas que eu posso aproveitar de você e você de mim". Só que professor, eu vou te falar, é muito corporativista e ele entende que ele entrou na sala de aula e fechou a porta, ele pode fazer o que quiser dentro, porque ele é o senhor e soberano. É verdade "até o segundo parágrafo", porque o fato de você estar confinado num espaço físico, você estar protegido por paredes, te garante que você faça longe dos olhos públicos naquele momento, mas você tem um monte de responsabilidades que você tem que cumprir ali dentro. Você tem que dar conta daquilo, seu papel, a expectativa do outro. E eu sempre fui favorável [à troca entre professores]... Aqui, na reunião, saiu isso: "Por que você não me convida para assistir uma aula sua?" "Mas não é sua disciplina". Não interessa, eu não quero ver seu conteúdo: quero ver você em sala, quero ver como você é... (Docente 6, 56 anos).

As contribuições dos docentes corroboram a afirmação de Masetto (2003): os saberes pedagógicos e a prioridade a seu desenvolvimento ainda são os pontos mais frágeis do professor do ensino superior. Porém, também percebemos que eles começam a se conscientizar de seu papel de educadores, que exige não apenas saberes disciplinares ou experienciais, mas principalmente a capacitação pedagógica que favorece significativamente a autonomia do aluno com a sua aprendizagem.

Sim, o saber pedagógico tem uma relação direta com a qualidade do ensino e aprendizagem. Porque esse é o foco. No final de tudo, não existe "eu dei uma boa aula", se não teve aprendizagem. Não existe. [...] Acho que o foco de tudo é aumentar a aprendizagem e empoderar o aluno (Docente 1, 40 anos). 
As entrevistas foram concluídas com uma autorreflexão dos docentes sobre os pontos fortes e os pontos a desenvolver de seus saberes pedagógicos. Parte dos entrevistados citaram fatores relativos à docência de forma mais ampla, revelando certa dificuldade de refletir sobre a questão.

Novamente, se destacou a relação com os alunos: $62,5 \%$ dos docentes consideraram como ponto forte a genuína relação (D1), o diálogo e a proximidade (D2), o relacionamento e a percepção (D4), o foco no ser humano e em suas necessidades (D7) e a disponibilidade e a atenção na interação em aula (D3).

O que eu sinto é assim: quando parei de querer ser infalível na sala de aula, acho que a aula teve uma melhoria de qualidade monstruosa, porque acho que o professor que quer ser infalível acaba competindo com o aluno. Aí, um dia, caiu a ficha: "eu não estou competindo, a gente está junto". E acho que começou a ter uma troca muito mais sincera. Teve muito mais participação. Acho que isso [...] foi um negócio que caiu a ficha e fez a diferença pra mim (Docente 1, 40 anos).

Meu ponto forte? Acho que essa questão da exposição com a troca de ideias. Na verdade, me vejo muito não como o professor que está lá falando, falando, expondo, expondo, mas sim como uma troca de ideias. Até porque eu faço link, mais uma vez, da literatura com o dia a dia. Eu percebo que fica fácil que eles entendam, aproxima (Docente 2, 32 anos).

Acho que depende muito da turma, mas, se eu tivesse que escolher, eu diria que é a minha capacidade de ler a turma e me relacionar. Eu consigo mapear a turma, o que vem se tornando cada vez mais difícil, pelo perfil heterogêneo (Docente 4, 42 anos).

A conduta centrada no ser humano e nas suas demandas, o comportamento orientado para a sala de aula democrática, as habilidades de planejamento, a abertura para novas metodologias e flexibilidade para efetivar mudanças. Valorização da multi e da interdisciplinaridade, e facilidade nas conexões teórico-conceituais (Docente 7, 57 anos).

Um ponto que é positivo [...] eu não tenho muito apego àquilo que planejei para minha aula. Então, se por acaso naquela turma específica, naquele dia específico, eu percebo que tem muito mais sentido a gente parar para ter uma conversa ou tirar dúvidas, para mim, isso é muito confortável, não é algo que me deixa ansiosa. Essa preocupação, se está tendo sentido, se está agregando valor para eles, eu acho que isso é uma coisa positiva. $E$ isso eu acho que é uma coisa que eles percebem também, que eu estou lá para eles. Mas eu estou lá para eles para aquilo que tem sentido. Então, enquanto eu não percebo que está todo mundo junto no mesmo ritmo, a gente continua conversando, eu continuo dando atenção (Docente 3,36 anos). 
Também foram reconhecidas as consequências da relação construtiva com o aluno pertencente aos saberes pedagógicos: maior participação dos alunos e melhor qualidade de aula (D1), favorecimento da aprendizagem dos alunos (D2) e capacidade de improvisação para que o conteúdo tenha sentido e agregue valor aos alunos (D3).

Como declarou o D7, a importância se estende à capacidade de planejar a disciplina, fazer conexões conceituais, valorizar a interdisciplinaridade, inovar na introdução de metodologias de aprendizagem e ser aberto a mudanças nas aulas.

De maneira reflexiva, a D3 comentou que sua habilidade de comunicação também seria um ponto forte entre seus saberes pedagógicos, mas, em certos casos, pode precisar melhorar. Explicou que sua paixão pelo tema algumas vezes a faz se prolongar na explicação, passando do tempo previsto no planejamento e não sendo uma experiência interativa de aprendizagem.

Eu acho que a explanação é um ponto forte e um ponto fraco, porque eu gosto muito de falar. Sobre os temas que eu trabalho, eu gosto muito de falar. Então, eu falo bem sobre eles, só que eu fico sempre muito atenta a como a plateia está reagindo, se [...] aquele tema eles já entenderam, se podemos passar para o próximo ou se tenho que reforçar. Tenho esse feeling, mas às vezes eu me apaixono um pouco demais e eu falo. Vai para o lado negativo. A explanação é boa, eu não tenho problema de falar, eu não tenho problema de pensar enquanto estou falando, em observar as pessoas enquanto eu estou falando, mas, quando eu estou apaixonada por aquele tema, tendo a ficar um pouco mais... Meu observador interno tem que ficar um pouco mais atento se eu vir que estou me apaixonando por aquilo. Tenho que dosar um pouco mais. Às vezes, para eles [...] está prazeroso, mas, em termos de planejamento e tempo, a gente poderia muito bem ter parado cinco minutos antes (Docente 3, 36 anos).

Igualmente, o D8 considerou sua comunicação um aspecto consolidado de seus saberes pedagógicos e realçou ainda o repertório de conhecimento e experiência no tema da disciplina, que seriam parte dos saberes disciplinares e experienciais.

Comunicação. Eu acho que a comunicação é uma coisa muito importante. E o repertório, eu acho que você tem de ter repertório pra comunicar com substância. Comunicar não é falar três horas numa aula de pós-graduação. Você tem de comunicar, você tem que ter repertório pra fazer uma comunicação com substância (Docente 8, 64 anos). 
O planejamento da disciplina e o domínio da estruturação das aulas foram os pontos que o D5 reputou como fortes. Em sua percepção, são eles que proporcionam a flexibilidade para adequar as aulas à necessidade dos alunos.

Eu acho que, em termos de pontos fortes, é a minha preparação. Isso gosto bastante, tenho facilidade de memorizar. Então, sei o que vou dar da primeira à última aula. Tenho um mapa mental. Então, consigo transitar, consigo ir pra avanços, depois consigo resgatar com eles. E, quando chega nesse momento, consigo pular, não preciso perder tempo com isso. $E$ a flexibilidade também é um negócio importante, que é tentar dar o conteúdo para a turma, isso procuro sempre fazer, é um ponto forte (Docente 5,32 anos).

Já para a D6, a capacidade de vincular teoria e prática e a visão sistêmica da carreira profissional docente são os destaques entre seus saberes pedagógicos. Ela foi quem se mostrou mais preocupada com a carreira do docente do lato sensu. Isso pode estar relacionado com o fato de que, mesmo sendo consultora educacional e coach profissional, dedica cerca de 30 horas semanais à docência, com experiência de 14 anos como docente. Ou seja, realmente a considera uma profissão.

Tenho facilidade e agilidade para amarrar a teoria com a prática e visão sistêmica em relação à carreira docente (Docente 6, 56 anos).

Sobre os aspectos a desenvolver, os dois docentes com mais experiência (D7, 29 anos, e D8, 34 anos) gostariam de aperfeiçoar e atualizar seus saberes disciplinares na área de conhecimento em que atuam.

Por estar aposentado e lecionar apenas como convidado, quatro horas semanais, o D8 confessou que "chegou no seu limite" em relação ao seu desenvolvimento como docente, mas que procura manter o padrão alcançado em suas aulas e estar sempre atualizado com informações técnicas e publicações de sua área.

Eu acho que, como docente, o que tinha de fazer já cheguei ao meu limite, não consigo mais que isso. Tem uma hora que você chegou no limite, você não vai além daquilo. Mas procuro manter esse limite. $\mathrm{Na}$ verdade, o que posso acrescentar é leitura, estar up to date com coisas que estão sendo publicadas na sua área, atualização técnica do assunto. Então, atualização. O modus operandi, você já passou por tantas experiências, já passou por tanta coisa... (Docente 8, 64 anos). 
Ao passo que o D7 percebe como necessidade de atualização não apenas os saberes disciplinares adquiridos a partir de estudos, pesquisa e produção intelectual, mas também os saberes experienciais, com mais envolvimento na prática e em atividades relativas à atuação profissional da disciplina.

A melhorar: a dedicação integral à docência gerou certo afastamento da prática profissional dos alunos. Ampliar participação em atividades relacionadas a área de atuação (fóruns, simpósios etc.). E ampliar a dedicação aos estudos e à pesquisa, pensando na atualização dos saberes. Investir mais tempo na produção intelectual dirigida às necessidades dos alunos e do curso (Docente 7, 57 anos).

A relação com o aluno foi destacada como aspecto forte de mais da metade dos docentes, mas também foi citada por dois entrevistados como ponto a ser aprimorado. O D4 relatou sua dificuldade para lidar com a nova geração de alunos do lato sensu, que às vezes se colocam criticamente diante de seus comentários em aula. Portanto, ele precisa rever alguns discursos inadequados ao perfil desses alunos. A D6 identificou como ponto a desenvolver sua interpretação do comportamento dos alunos, com a finalidade de aprimorar sua atuação docente.

As pessoas estão ficando mais difíceis. Aí, eu acho que é uma coisa que eu tenho me policiado, que é onde eu mais erro, eu sou meio "politicamente incorreto". É muito difícil conviver com essa geração. Isso é um exercício que eu tenho que fazer o tempo todo. Por exemplo: uma aluna pediu uma orientação sobre sua escrita, contei que eu escrevo numa revista, termino o texto em algum momento e dou para a minha mulher ler, porque sei que, dali pra frente, eu vou estragar. Depois que ela ler, ela vai achar 18 problemas e vai deixar escapar só um, porque mulher é detalhista, você sabe como é, não vai deixar escapar. A aluna levantou e fez um discurso feminista: "o senhor vai querer discutir gênero agora, professor?" E tende a piorar. As pessoas não aceitam, não entendem, e isso realmente é difícil pra mim. Cometo várias gafes nesse sentido (Docente 4, 42 anos).

A melhorar, a questão da psicologia, do comportamento, mas isso é um projeto que envolve cinco anos. Pensando em curto prazo, vou buscar algumas formações em técnicas específicas, para me ajudar a cobrir essa questão da leitura do comportamento, uma leitura mais rápida do indivíduo para desenvolvimento da docência (Docente 6, 56 anos).

Por fim, a preparação pedagógica e a experiência como docente foram mencionadas por quatro docentes como aspectos a melhorar (D1, D2, D3 e D4). Observamos são os entrevistados com menor tempo de experiência como docente, sendo três deles especialistas sem formação pedagógica. 
A D3 expressou que deseja desenvolver a dinâmica de suas aulas para que sejam menos expositivas, mas não se sente devidamente preparada para conduzir outros formatos.

\begin{abstract}
Eu acho que uma coisa que eu preciso desenvolver, mas isso leva um pouco mais de tempo, eu queria muito que as aulas fossem mais dinâmicas do que elas já são. Então, uma outra forma de apresentar a fundamentação teórica, que não seja tão pesada ou tão expositiva, eu acho que isso leva tempo para você construir. Será que depois eu vou perguntar para ele de onde surgiu ou quais são os principais teóricos, qual a visão deles, eles saberiam responder, me explicar da mesma forma, se não tivesse a exposição? Eu acho que isso hoje me incomoda. Vejo que tem muita coisa sendo construída nesse sentido, para que as aulas sejam menos expositivas, mas eu ainda fico um pouco insegura de não ter nada de exposição. Apesar de gostar muito de dinâmica, fazer dinâmica, me sentir bem confortável, mas sem a exposição... (Docente 3, 36 anos).
\end{abstract}

A aplicação de diferentes metodologias de aprendizagem também foi uma preocupação manifestada pelo D2, que gostaria de usá-las para facilitar a aprendizagem dos alunos dos conceitos técnicos de sua disciplina. Ele e o D5 citaram o mestrado como um possível caminho para seu desenvolvimento como docentes, sendo para o D5, relativo aos seus saberes disciplinares. Ele também citou a necessidade de entender melhor as possibilidades do processo avaliativo para poder sugerir mudanças no sistema atual.

A melhorar, tem algumas questões que são muito técnicas do tema e eu que preciso achar alguma forma de traduzir. Talvez eu precise melhorar nessas questões mais técnicas, que realmente não são e talvez nunca tenham sido abordadas por eles, principalmente entre os alunos que são de humanas. Que é bem a questão pedagógica.

Sou administrador de formação, como você. Somos colegas de profissão, [...] e pretendo, assim que tiver um tempinho, fazer o mestrado. Acho que é um caminho, acho que é importante. A gente que está demonstrando isso, pretende ter esse viés de educação, é importante que você consiga [...] alinhar a experiência com a academia. Acho que o mestrado traz muito isso (Docente 2, 32 anos).

Eu acho que devo essa capacitação stricto sensu que estou buscando no mestrado. Acho que tem algumas coisas que, por mais que você leia, por mais que seja importante, como citar autor, então, acho que ainda sinto falta. Não sei se algum dia ainda vou suprir. Conhecer todos autores, nunca vou. [...] E o outro ponto é mais experiência, mesmo. É a parte da prova, que é uma coisa que sempre achei ruim no sistema de ensino global. Nesse caso, nas IES, não teve prova. Mas o importante da prova não é o certo ou errado, mas o que o aluno entendeu. Tem de entender o conceito central. Uma prova de papel de $X$ [de múltipla escolha] não funciona. Uma prova discursiva, você precisa ter método pra corrigir. Senão, você acaba dando por empatia 
mesmo, e isso é péssimo, não avalia. Eu não gosto de dar toda semana um trabalho pra fazer, sendo que a maioria deles trabalha em empresa, como eu. Daí, o professor, por preguiça de ler, pede pra apresentar (Docente 5, 32 anos).

Mesmo com as formações de que participou e sendo doutorando, o D1 ainda sente falta da técnica didática, pois cursou apenas um semestre de uma disciplina sobre o tema e só tem três anos de experiência como docente, apesar de também conduzir treinamentos corporativos, que reforçam algumas habilidades:

Me falta experiência, me falta muita técnica didática, tive um semestre de aula [de didática] e quero mais (Docente 1, 40 anos).

Como vimos, as entrevistas dos oito docentes de cursos lato sensu da IES selecionada revelaram percepções importantes sobre os saberes pedagógicos.

As categorias de análise foram fundamentais para a organização dos dados, pois permitiram investigar os aspectos relevantes e recorrentes que conduziram às conclusões desta pesquisa. 


\section{CONCLUSÃO}

O principal objetivo desta pesquisa foi analisar os saberes pedagógicos de docentes de pós-graduação lato sensu que lecionam em uma IES da cidade de São Paulo.

O trabalho partiu de um breve histórico da evolução do ensino superior no Brasil e da contextualização atual dos cursos lato sensu. Em seguida, aprofundou a conceituação dos saberes pedagógicos, o que fundamentou a pesquisa de campo com os próprios docentes do lato sensu sobre seu conhecimento e a aplicação desses saberes na prática da sala de aula.

Os resultados das entrevistas com os oito docentes da amostra confirmaram a hipótese e levaram a outras considerações relevantes para a educação.

A pergunta sobre a formação pedagógica prévia à atuação docente revelou que apenas um participante havia tido preparação, mas ela não contemplava a especificidade do ensino superior. Portanto, $87,5 \%$ dos entrevistados iniciaram a docência sem a devida capacitação pedagógica, contando apenas com suas referências de professores inspiradores de seu tempo de alunos e/ou com habilidades adquiridas na condução de treinamentos em sua experiência corporativa ( $75 \%$ dos docentes).

As justificativas apresentadas foram que o desenvolvimento dos saberes disciplinares e experienciais relativos à área de especialização do curso de atuação dos docentes do lato sensu tem prioridade sobre os saberes pedagógicos em função da natureza e do objetivo dos próprios cursos, bem como das expectativas de aprendizagem pragmáticas dos alunos. Complementarmente, constatamos a fragilidade da regulamentação e da avaliação dos cursos lato sensu orientadas pelo MEC e aplicadas pela IES pesquisada, as quais não exigem formação pedagógica dos docentes.

Assim, confirmou-se que os saberes pedagógicos dos docentes não são priorizados no lato sensu e que só passam a ser valorizados quando, já lecionando, os próprios docentes se sensibilizam diante da necessidade de se desenvolver e de construir uma identidade profissional. A pesquisa de campo revelou que a maioria dos 
entrevistados (todos com no mínimo três anos de atuação) reconhece a relevância dos saberes pedagógicos no processo de ensino e aprendizagem, mas não priorizam seu desenvolvimento pelos motivos citados. Um dos entrevistados chegou a afirmar que, no lato sensu, considera os saberes disciplinares e experienciais mais importantes que os pedagógicos.

Entretanto, a postura tradicional, baseada principalmente nos saberes disciplinares e experienciais e no ensino centrado no professor, foi questionada pelos docentes, mostrando que é um modelo a ser transformado e ressignificando também a identidade profissional. Esse questionamento foi acompanhado da crítica ao stricto sensu, que não capacita os alunos para a docência, mas enfatiza apenas o conhecimento técnico e a pesquisa. Confirmamos essa percepção ao verificar que, dos cinco docentes com titulação stricto sensu (62,5\%), apenas dois haviam cursado disciplinas sobre didática durante a formação, mas por iniciativa própria, pois não eram obrigatórias.

Para entender os saberes pedagógicos, tivemos que antes conhecer melhor o docente do lato sensu. Consequentemente, constatamos que, de fato, os perfis são heterogêneos em diversos aspectos, sobretudo quanto à formação e à experiência profissional. Como bem observa Silva (2009), essa heterogeneidade se verifica também nas diferentes disciplinas e cursos em que lecionam, na forma de contratação (pela CLT ou por carta-convite), na habilitação acadêmica e profissional, no tempo de serviço e na dimensão da instituição, entre outros aspectos.

O envolvimento do grupo de docentes em ações extraclasse como a participação em ações formativas e em pesquisas como esta é restrito, visto que $41 \%$ da amostra responderam à pesquisa on-line e $20 \%$ concordaram em ser entrevistados. Provavelmente, isso se deve à dedicação restrita desses docentes (média de 18 horas semanais) e ao tipo de vínculo com a IES, por tempo determinado (por carta-convite) (69\%), considerando que apenas $25 \%$ se dedicam exclusivamente à profissão docente.

Os únicos aspectos comuns foram o fato de que, antes da docência, todos os docentes tinham uma carreira empresarial (como gestores ou consultores) e a 
formação na respectiva área, o que reitera a prioridade ao desenvolvimento dos saberes disciplinares e experienciais dos docentes do lato sensu.

Após as entrevistas, constatamos que a maioria dos docentes $(87,5 \%)$ valoriza os saberes pedagógicos, embora não demonstrassem um conhecimento avançado a respeito e muitas vezes não os distinguissem dos saberes disciplinares ou dos experienciais.

Quanto à autorreflexão dos docentes sobre seus saberes pedagógicos, verificamos que foram identificados durante sua própria prática em sala de aula. Tratase de um conhecimento empírico, construído ao longo da experiência docente e, em alguns casos, com o apoio de formação pedagógica breve ou de ações educacionais pontuais e autodirigidas, mas sem um fundamento teórico educacional.

A principal dimensão pedagógica considerada relevante pelos entrevistados foi a relação construtiva com os alunos. Embora com diferentes intensidades e visões, todos reconhecem a importância do vínculo estabelecido em aula. Termos como humanização, empatia, sensibilidade, confiança, autonomia e flexibilidade mostraram a preocupação com o principal elemento do processo de ensino e aprendizagem: o aluno. Portanto, todos percebem o benefício de seu engajamento, que resulta em aulas melhores e na aprendizagem significativa dos alunos.

A relação construtiva mostrou-se aliada do desenvolvimento de um pensamento mais crítico e complexo do aluno, como declararam $62,5 \%$ dos docentes entrevistados. Portanto, insatisfeitos com a expectativa dos alunos do aprendizado pragmático, a maior parte dos docentes da IES selecionada se mobiliza para articular com os alunos uma aprendizagem significativa de modo a capacitá-los a tomar decisões melhores na profissão, o que revelou um aspecto importante para o processo de ensino e aprendizagem nos cursos lato sensu.

Em outra oportunidade, se poderiam acompanhar aulas desses docentes e também ouvidos os alunos, para confirmar ou não essas constatações dos docentes e para conhecer melhor a opinião dos alunos sobre os saberes pedagógicos. O que foi possível constatar, a partir do ponto de vista dos docentes, é que esses alunos têm expectativas pragmáticas voltadas para o mundo de trabalho, mas tal fato não permitiu afirmar uma relação de causa e efeito entre o desenvolvimento dos saberes 
pedagógicos dos docentes e a avaliação dos alunos sobre sua própria aprendizagem, o docente e a disciplina.

A expectativa quanto às metodologias de ensino e aprendizagem adotadas pelos docentes não foi correspondida neste estudo. Existe um grande potencial para expandir esse repertório, especialmente no que tange a metodologias que promovam a autonomia do aluno a partir de formatos digitais. Por exemplo, se poderiam desenvolver projetos ligados a pesquisa de campo e benchmarking com empresas referências no setor, com o compartilhamento desses resultados em blogs de aprendizagem e fóruns de discussão na plataforma virtual da IES.

Esse potencial foi reconhecido com a aplicação da metodologia PBL e do recurso diário de bordo, adotados por entrevistados. Porém, para ampliar essa perspectiva, o docente do lato sensu deve estar atualizado não apenas com o conteúdo de sua disciplina e com informações do mercado, mas também com os tipos de metodologia de aprendizagem e suas possibilidades digitais para o universo do lato sensu.

Sabemos que é imprescindível que o docente seja o protagonista desse processo de desenvolvimento pedagógico, mas a participação das IES é fundamental. A partir dos resultados desta pesquisa, entendemos que a IES selecionada precisa ampliar e direcionar melhor suas ações formativas para favorecer o desenvolvimento dos saberes pedagógicos dos docentes do lato sensu. A criação de espaços para análise e discussão da formação de docentes foi também recentemente defendida por Nóvoa (O lugar [...], 2016):

\footnotetext{
Onde está o lugar em que nos sentamos à volta de uma mesa para pensar como se forma o professor? Esse lugar muitas vezes não existe nas instituições de ensino superior. Gostaria de convidar as universidades a criarem essa casa comum para a formação de professores. Pode ser um prédio, um colegiado; cada universidade decidirá o que quer fazer, mas tem de haver um lugar, um espaço, onde se reflita sobre essa formação.
}

Nas entrevistas, apenas quatro docentes mencionaram ações de formação pedagógica promovidas pelas IES em que eram contratados pela CLT e apenas dois deles haviam participado, por serem elas facultativas. A IES selecionada promove 
ações desse tipo, mas são opcionais e nem sempre bem divulgadas entre os docentes temporários (por carta-convite).

Constatou-se que a tentativa de desenvolver os saberes pedagógicos é autodirigida, ou seja, o docente sensibilizado procura participar de eventos ou grupos em sua área de atuação, ler publicações especializadas ou envolver-se em ações que renovam seu conhecimento por motivação própria, como as trocas de experiências com outros colegas, citadas nas entrevistas.

Portanto, a formação pedagógica promovida pela IES deve ser baseada nas necessidades e nos interesses dos docentes do lato sensu e acompanhada pelos coordenadores dos cursos, que são importantes elementos de apoio à preparação e à atuação do docente. Nesse sentido, o trabalho conduzido pelos núcleos pedagógicos de outras IES, citados por alguns entrevistados, mereceriam posterior averiguação para referências de formação pedagógica.

O desenvolvimento continuado dos saberes pedagógicos poderia ser liderado pelos coordenadores dos cursos lato sensu da IES, sobretudo com os docentes iniciantes. Isso poderia favorecer principalmente o conhecimento de processos de ensino e aprendizagem, a visão e o trabalho interdisciplinar implicados no trabalho de conclusão de curso (TCC), questionamentos e revisões do processo avaliativo, a reflexão sobre a identidade profissional e, ainda, o compartilhamento de boas práticas de relacionamento interpessoal, que foi a dimensão dos saberes pedagógicos destacada pelos entrevistados.

Um importante suporte para essas ações formativas seria a mobilização do MEC para fortalecer regulamentações que amparem o desenvolvimento dos saberes pedagógicos a partir da obrigatoriedade de disciplinas específicas no stricto sensu, do incentivo a ações formativas aos docentes nas IES e do acompanhamento de seus cursos. Dessa forma, poderíamos formar docentes que se percebam como profissionais integrados, capazes de uma contínua construção de seus saberes pedagógicos, disciplinares e experienciais.

Concluímos que é preciso estimular e incrementar permanentemente a conscientização sobre a identidade profissional e a importância dos saberes pedagógicos dos docentes do lato sensu, e que esse será o primeiro passo para o 
contínuo desenvolvimento desses saberes, favorecendo seus conhecimentos e também suas práticas educacionais.

Investigar um tema tão relevante para a educação e poder contribuir com o desenvolvimento de professores do lato sensu, um universo ainda carente de estudos, foi uma excelente experiência como pesquisadora e como docente. A expectativa é que seja também uma oportunidade de reflexão para os docentes e as IES, sensibilizando-os para a importância dos saberes pedagógicos do docente do lato sensu. 


\section{REFERÊNCIAS}

ALMEIDA, L. R.; MAHONEY, A. A. (Org.). Afetividade e aprendizagem: contribuições de Henri Wallon. São Paulo: Loyola, 2007.

ALMEIDA, M. I. M. Formação do professor do ensino superior: desafios e políticas institucionais. São Paulo: Cortez, 2012.

ALMEIDA, M. I. M.; PIMENTA, S. G. Pedagogia universitária: caminhos para a formação de professores. São Paulo: Cortez, 2011.

ALVES, A. J. O planejamento de pesquisas qualitativas em educação. Cadernos de Pesquisa, São Paulo: Fundação Carlos Chagas, n. 77, maio 1991. Disponível em: <http://educa.fcc.org.br/scielo.php?pid=S010015741991000200006\&script=sci_arttext>. Acesso em: 25 nov. 2015.

ANDRÉ, M. E. D. A. Pesquisa em educação: buscando rigor e qualidade. Cadernos de Pesquisa, São Paulo: Fundação Carlos Chagas, n. 113, p. 51-64, jul. 2001.

AQUINO, C. T. E. Como aprender andragogia e habilidades de aprendizagem. São Paulo: Person, 2007.

BERBEL, N. A. N. Metodologia do ensino superior: realidade e significado. Campinas, SP: Papirus, 1994.

BIREAUD, A. Os métodos pedagógicos no ensino superior. Porto: Porto, 1995.

BLOOM, B. S. et al. Taxonomy of educational objectives. New York: David Mckay, 1956.

BOSI, A. P. A precarização do trabalho docente nas instituições de ensino superior no Brasil nesses últimos 25 anos. Revista Educação \& Sociedade, Campinas, SP, v. 28, n. 101, p. 1503-1523, set./dez. 2007.

BRASIL. Ministério da Educação. Conselho Nacional de Educação. Câmara de Educação Superior. Resolução n. 1, de 8 de junho de 2007. Estabelece normas para o funcionamento de cursos de pós-graduação lato sensu em nível de especialização. Disponível em: <http://portal.mec.gov.br/cne/ arquivos/pdf/rces001_07.pdf>. Acesso em: 19 abr. 2017.

BRASIL. Câmara dos Deputados. Relatório do Grupo de Trabalho da Reforma Universitária, criado pelo Decreto $n^{\circ} 62.937 / 1968$. Brasília, DF: MEC/MPCG/MF, ago. 1968.

CHAMLIAN, H. C. A formação de professores para o ensino superior é possível e desejável? In: PINHO, S. Z. (Org.). Formação de educadores: o papel do educador e sua formação. São Paulo: Editora UNESP, 2009. p. 215-230. 
CHAMLIAN, H. C. As histórias de vida e a formação do professor universitário. In: SOUZA, E. C.; ABRAHÃO, M. H. Autobiografias, histórias de vida e formação. Porto Alegre: EDIPUCRS, 2006. p. 75-91.

Experiências de pesquisa: o sentido da universidade na formação docente. Tese (Livre-docência em Ciências Humanas) - Faculdade de Educação, Universidade de São Paulo, São Paulo, 2005.

. Professores inovadores da USP e a questão da formação do docente universitário. Cadernos de Pesquisa, São Paulo: Fundação Carlos Chagas, n. 118, p. 41-64, mar. 2003.

CHAVES, V. L. Expansão da privatização/mercantilização do ensino superior brasileiro: a formação de oligopólios. Revista Educação \& Sociedade, Campinas, SP, v. 31, n. 111, p. 481-500, abr./jun. 2010.

CUNHA, L. A. C. R. A pós-graduação no Brasil: função técnica e função social. Revista de Administração de Empresas, Rio de Janeiro, v. 14, n. 5, p. 6670, set./out. 1974.

CUNHA, M. I.; SOARES, S. R.; RIBEIRO, M. L. (Org.). Docência universitária: profissionalização e práticas educativas. Feira de Santana, BA: UEFS, 2009.

ESTEVE, J. M. Mudanças sociais e função docente. In: NÓVOA, A. Profissão professor. Porto: Porto, 1995.

FERREIRA, F. I. Identidade dos professores: perspectivas teóricas e metodológicas. In: ESTRELA, A.; CANÁRIO, R.; FERREIRA, J. (Org.). Formação, saberes profissionais e situações de trabalho. Lisboa: VI Colóquio Nacional da AIPELF/AFIRSE, 1996. v. 1, p. 309-328.

FLORES, M. A. (Org.). Formação e desenvolvimento profissional de professores: contributos internacionais. Coimbra: Almedina, 2014.

GAETA, C.; MASETTO, M. T. O professor iniciante no ensino superior: aprender, atuar e inovar. São Paulo: Editora Senac, 2013.

GONÇALVES, A. C. Saberes e práticas docentes em cursos de lato sensu. Dissertação (Mestrado em Educação) - Faculdade de Humanidades e Direito, Universidade Metodista de São Paulo, São Bernardo do Campo, 2013.

GONÇALVES, J. A. Prática docente e identidade profissional. In: Formação, saberes profissionais e situações de trabalho. Formação, saberes profissionais e situações de trabalho. Lisboa: VI Colóquio Nacional da AIPELF/AFIRSE, 1996. v. 1, p. 363-377.

HALL, S. A identidade cultural na pós-modernidade. Rio de Janeiro: DP\&A, 2006. 
IMBERNÓN, F. Formação permanente do professorado: novas tendências. São Paulo: Cortez, 2009.

INEP. Instituto Nacional de Estudos e Pesquisas Educacionais Anísio Teixeira. Censo 2016. Disponível em: <http://download.inep.gov.br/educacao_superior/ censo_superior/documentos/2015/notas_sobre_o_censo_da_educacao_super ior_2014.pdf>. Acesso em: 15 nov. 2016.

KNOWLES, M. S. The modern practice of adult education: andragogy versus pedagogy. Englewood Cliffs: Prentice Hall, 1980.

LUDKE, M.; ANDRÉ, M. E. D. A. Pesquisa em educação: abordagens qualitativas. São Paulo: EPU, 1986.

MANZINI, E. J. Uso da entrevista em dissertações e teses produzidas em um programa de pós-graduação em educação. Revista Percurso, São Paulo, v. 4, n. 2, p. 149-171, 2012.

MASETTO, M. T. (org.). Docência na universidade. Campinas, SP: Papirus, 2014.

O professor na hora da verdade: a prática docente no ensino superior. São Paulo: Avercamp, 2010.

Competência pedagógica do professor universitário. São Paulo: Summus, 2003.

MEC. Ministério da Educação. Secretaria de Articulação com os Sistemas de Ensino. Planejando a próxima década: conhecendo as 20 metas do Plano Nacional de Educação. Brasília, DF: MEC/SASE, 2014. Disponível em: $<$ http://pne.mec.gov.br/images/pdf/pne_conhecendo_20_metas.pdf >. Acesso em: 7 out. 2016.

. IGC - Apresentação, [s.d.]a. Disponível em: <http://portal.mec.gov.br/igc >. Acesso em: 23 abr. 2017.

. Lato-sensu: saiba mais, [s.d.]b. Disponível em: <http://portal.mec.gov.br/ pos-graduacao/pos-lato-sensu>. Acesso em: 19 abr. 2017.

MELUCCI, A. O jogo do eu: a mudança em si em uma sociedade global. São Leopoldo, RS: Ed. Unisinos, 2004.

NÓVOA, A. Profissão professor. 2a ed. Porto: Porto, 1995. . Formação de professores e profissão docente. NÓVOA, A. (Coord.). Os professores e a sua profissão. Lisboa: Dom Quixote, 1992. 
OLIVEIRA, F. B. Origem e evolução dos cursos de pós-graduação lato sensu no Brasil. Revista de Educação Pública - FGV. Rio de Janeiro, v. 29, n. 1, p. 19-33, jan./mar. 1995. Disponível em: <http://bibliotecadigital.fgv.br/ojs/ index.php/rap/article/view/8285>. Acesso em: 20 out. 2015.

OLIVEIRA, M. A. O.; CUNHA, I. C. K. O. Pós-graduação lato sensu: retrospectiva histórica e política atual. In: CONGRESSO NACIONAL DE EDUCAÇÃO, 10., 2009, Curitiba: PUC-PR. Disponível em:

<http://www.pucpr.br/eventos/educere/educere2009/anais/comunicacoes_9.ht ml>. Acesso em: 11 dez. 2015.

O LUGAR da licenciatura. Entrevista com António Nóvoa. Revista Educação, São Paulo: Segmento, 8 nov. 2016. Disponível em:

<http://www.revistaeducacao.com.br/o-lugar-da-licenciatura/>. Acesso em: 14 nov. 2016.

PIMENTA, S. G. (Org.). Saberes pedagógicos e atividade docente. São Paulo: Cortez, 2007.

PIMENTA. S. G.; ANASTASIOU, L. G. C. Docência no ensino superior. São Paulo: Cortez, 2011.

PLACCO, V. M. N. S.; SOUZA, V. L. T. (Org.). Aprendizagem do adulto professor. São Paulo: Loyola, 2006.

PRESIDÊNCIA DA REPÚBLICA. Casa Civil. Subchefia para Assuntos Jurídicos. Lei n. 9.394, de 20 de dezembro de 1996 (Lei de Diretrizes e Bases - LDB). Estabelece as diretrizes e bases da educação nacional. Disponível em: <http://www.planalto.gov.br/ccivil_03/Leis/L9394.htm>. Acesso em: 24 nov. 2015.

ROGERS, C. Tornar-se pessoa. Lisboa: Moraes, 1985.

SACRISTÁN, J. G. Consciência e aç̧ão sobre a prática como libertação profissional dos professores. In: NÓVOA, A. Profissão professor. Porto: Porto, 1995. p. 63-80.

SILVA, M. L. R. A complexidade inerente aos processos identitários docentes. Notandum Libro, São Paulo: Hottopos, v. 12, p. 45-58, 2009.

. Docentes, saberes e práticas escolares. In: LAUAND, L. J. (Org.). Filosofia e Educação: estudos 8. São Paulo: Factash, 2008. p. 23-34.

. Aspectos sócio-afetivos que interferem na construção da identidade do professor. In: SILVA, E. R.; UYENO, E. Y.; ABUD, M. J. M. (Org.). Cognição, afetividade e linguagem. São Paulo: Cabral, 2007. p. 235-259. 
SOARES, S. Pedagogia universitária: campo de prática, formação e pesquisa na contemporaneidade. In: NASCIMENTO, A. D.; HETKOWSKI, T. M. (Org.). Educação e contemporaneidade: pesquisas científicas e tecnológicas [online]. Salvador: EDUFBA, 2009. p. 93-107.

TARDIF, M. Saberes docentes e formação profissional. Petrópolis, RJ: Vozes, 2002.

TRIVIÑOS, A. N. S. Introdução à pesquisa em ciências sociais: a pesquisa qualitativa em educação. São Paulo: Atlas, 1987.

VASCONCELOS, M. L. M. C. Contribuindo para a formação de professores universitários: relato de experiências. In: MASETTO, M. T. (Org.). Docência na universidade. Campinas, SP: Papirus, 2014. p. 77-94.

ZABALA, A. A prática educativa: como ensinar. Porto Alegre: Artmed, 1998.

ZABALZA, M. A. O ensino universitário: seu cenário e seus protagonistas. Porto Alegre: Artmed, 2004. 


\section{APÊNDICE A - Questionário on-line aplicado aos docentes}

\section{Pesquisa on-line Mestrado}

Prezado colega, muito obrigada por sua disponibilidade e participação nesta pesquisa. Este questionário on-line, de apenas oito perguntas, tem como objetivo coletar seus dados pessoais, que contribuirão para a pesquisa de mestrado.

Por favor, responda-as com base em sua experiência como docente de cursos lato sensu. Todas as informações concedidas são confidenciais e serão utilizadas apenas para análise na dissertação de mestrado. O nome dos participantes e da instituição de ensino são confidenciais.

Caso tenha alguma dúvida, por favor, entre em contato.

Atenciosamente, Nadia Moura Farhat

(1) Por favor, informe os seus dados:

Idade:

Sexo:

Tempo de docência:

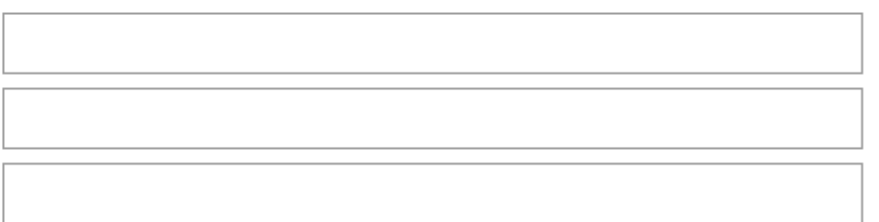

(2) Qual é a sua formaçāo acadêmica (graduaçāo e pós-graduaçāo)?

Graduaçāo:

Pós-graduaçāo

(especificar lato ou

stricto sensu):

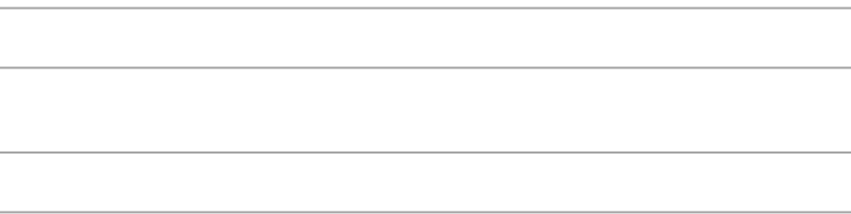


APÊNDICE A - Questionário on-line aplicado aos docentes

(3) Quais disciplinas você está conduzindo como docente atualmente? Disciplina e curso: Disciplina e curso: Disciplina e curso: Disciplina e curso:

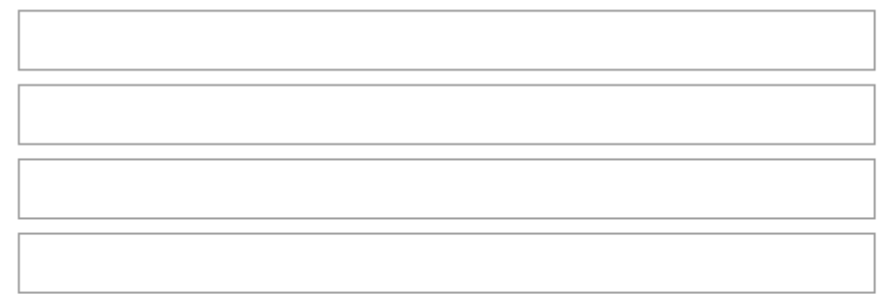

(4) Quantas horas semanais você dedica apenas à docência (incluindo conduçāo das aulas e atividades extraclasse)?

(5) Como é caracterizado o seu tipo de contrataçāo com a instituiçāo de ensino a qual estamos realizando a pesquisa?

Contratado CLT

Convidado temporário

6) Relate brevemente a sua experiência profissional como docente.

(7) Você também atua em outra profissāo além da docência?

$\operatorname{sim}$

Nāo

8) Caso positivo, qual seria essa outra profissāo? 


\section{APÊNDICE B - Roteiro semiestruturado da entrevista com os docentes}

\section{Pesquisa de Mestrado em Educação FEUSP}

Roteiro de entrevista com os docentes de lato sensu

1. Com base na sua experiência como docente, o que é esperado dos cursos lato sensu por parte do aluno, dessa instituição de ensino e da sociedade e por você mesmo.

2. Para alcançar essas expectativas, quais são o papel e as responsabilidades do docente do lato sensu?

3. Você teve alguma formação pedagógica formal para atuar em sala de aula?

4. Como você percebe a composição dos seus saberes pedagógicos, que são os conceitos educacionais, as técnicas, as metodologias e as estratégias mobilizadas para o processo de ensino e aprendizagem?

5. E como esses saberes foram desenvolvidos na sua carreira?

6. Descreva os aspectos teóricos dos seus saberes pedagógicos.

7. Relate a prática dos seus saberes pedagógicos considerando antes, durante e depois da sala de aula.

8. De que forma os saberes pedagógicos docentes são importantes num processo de ensino e aprendizagem em sala de aula?

9. Fazendo uma autorreflexão, quais são os pontos fortes e os pontos a desenvolver de seus saberes pedagógicos para os cursos lato sensu? 


\section{ANEXO - Termo de consentimento da entrevista}

\section{USP - UNIVERSIDADE DE SÃO PAULO \\ TERMO DE CONSENTIMENTO LIVRE E ESCLARECIDO}

\section{Sujeito participante da pesquisa de Mestrado em Educação - FEUSP}

Concordo em participar, como voluntário(a), da pesquisa de dissertação de Mestrado intitulada Saberes pedagógicos: um estudo com docentes de pósgraduação lato sensu de uma IES, sob a responsabilidade da pesquisadora Nadia Moura Farhat, aluna da Faculdade de Educação da Universidade de São Paulo (FEUSP), orientada pela $\operatorname{Prof}^{a} \operatorname{Dr}^{a}$ Maria de Lourdes Ramos Silva, com que se pode entrar em contato respectivamente pelos e-mails nadiamfarhat@usp.br e mlramos@usp.br.

O objetivo do presente trabalho é investigar como são compostos os saberes pedagógicos (teorias e práticas) de docentes de cursos de pós-graduação lato sensu de uma IES em São Paulo.

Minha participação consiste em contribuir com dados e informações sobre a profissão docente e seus saberes pedagógicos, realizada a partir de uma pesquisa virtual e uma entrevista presencial. Compreendo que esse estudo tem apenas finalidade de pesquisa, que os dados obtidos serão utilizados sem a divulgação do meu nome, seguindo as diretrizes éticas da pesquisa baseadas no Código de Ética da USP (Resolução n. 4.871/2001), assegurando, assim, minha privacidade.

Estou ciente de que posso retirar meu consentimento quando eu quiser e de que não receberei nenhuma remuneração por essa participação.

\section{Consentimento do (a) participante:}

Nome completo

Assinatura

Local, dia, mês e ano 